Prepared in cooperation with the U.S. Department of the Army

\title{
Hydrology, Water Quality, and Water-Supply Potential of Ponds at Hunter Army Airfield, Chatham County, Georgia, November 2008-July 2009
}
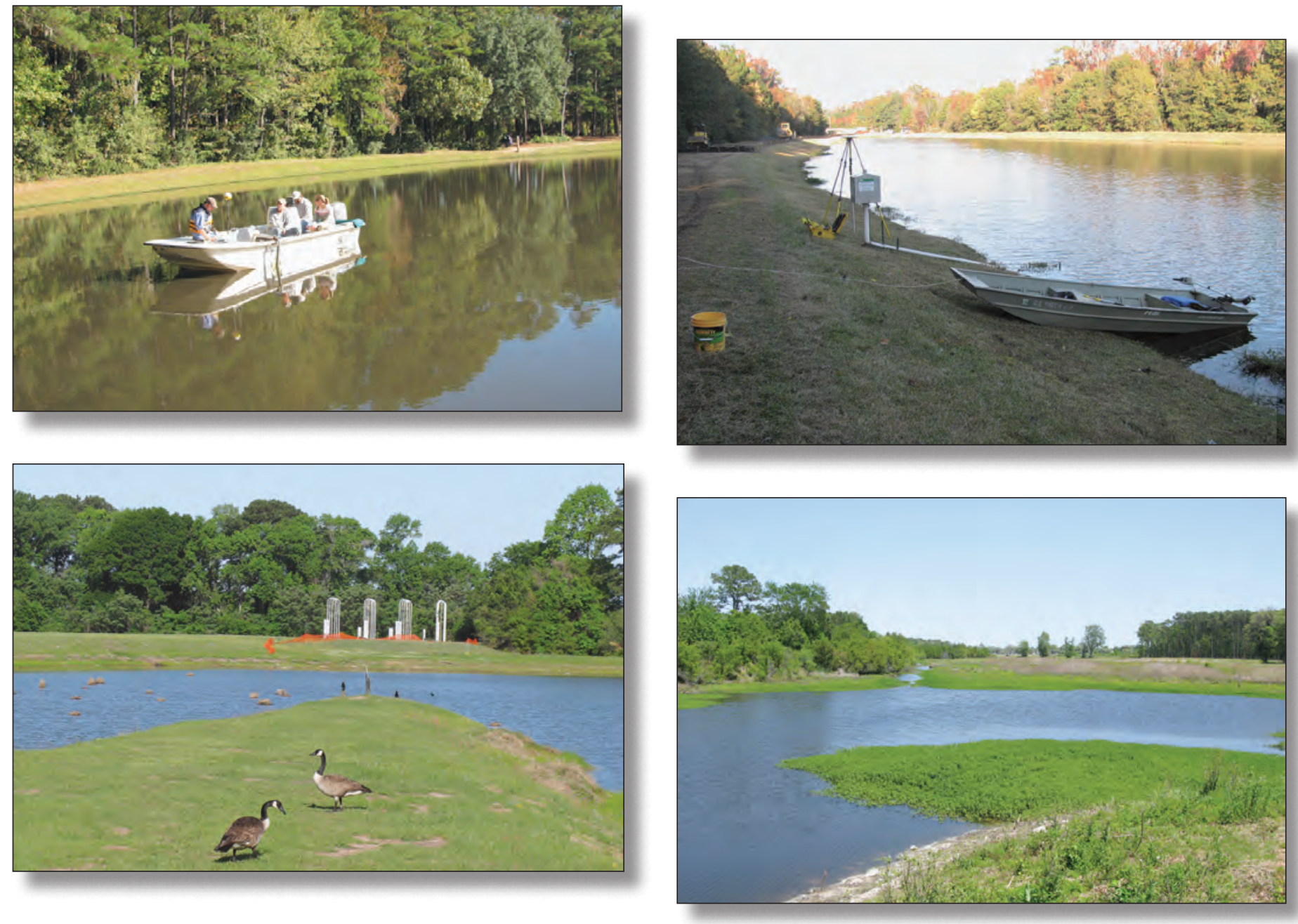

Scientific Investigations Report 2009-5265 
Cover. Photographs of ponds at Hunter Army Airfield, Chatham County, Georgia.
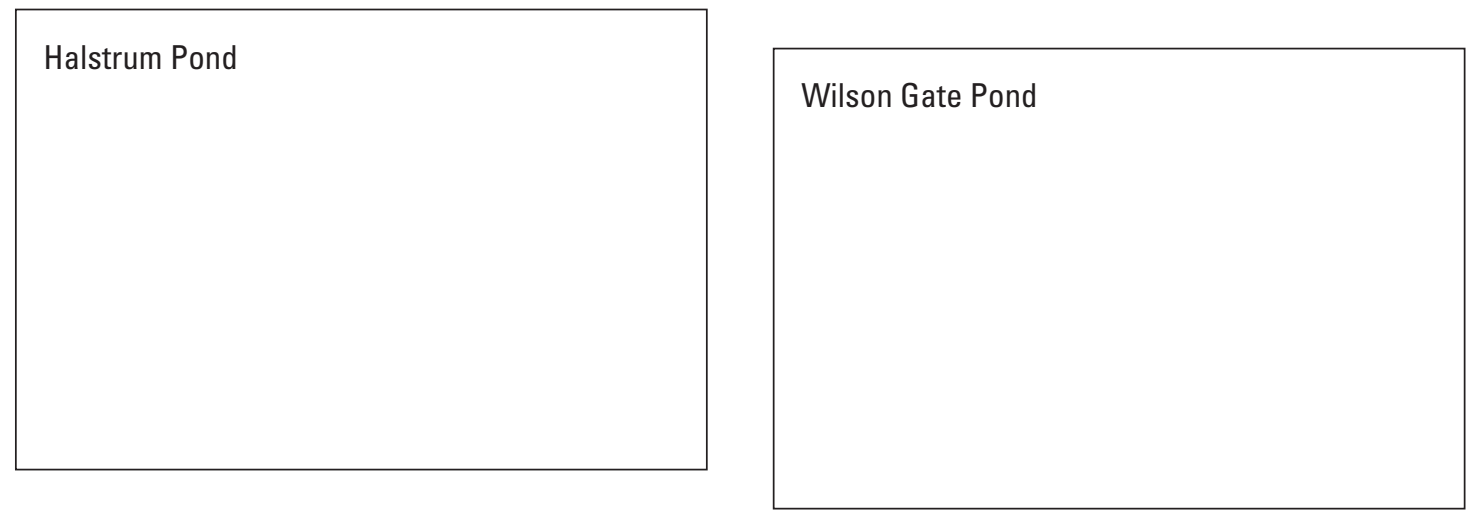

Oglethorpe Lake.

Photo by Michael D. Hamrick, USGS.

Golf Course Pond 


\section{Hydrology, Water Quality, and Water-Supply Potential of Ponds at Hunter Army Airfield, Chatham County, Georgia, November 2008-July 2009}

By John S. Clarke and Jaime A. Painter

Prepared in cooperation with the U.S. Department of the Army

Scientific Investigations Report 2009-5265 


\title{
U.S. Department of the Interior \\ KEN SALAZAR, Secretary \\ U.S. Geological Survey \\ Marcia K. McNutt, Director
}

\section{U.S. Geological Survey, Reston, Virginia: 2010}

\author{
For more information on the USGS — the Federal source for science about the Earth, its natural and living resources, \\ natural hazards, and the environment, visit http://Www.usgs.gov or call 1-888-ASK-USGS \\ For an overview of USGS information products, including maps, imagery, and publications, \\ visit $h t t p: / / w w w . u s g s . g o v / p u b p r o d$ \\ To order this and other USGS information products, visit http://store.usgs.gov
}

Any use of trade, product, or firm names is for descriptive purposes only and does not imply endorsement by the U.S. Government.

Although this report is in the public domain, permission must be secured from the individual copyright owners to reproduce any copyrighted materials contained within this report.

Suggested citation:

Clarke, J.S., and Painter, J.A., 2010, Hydrology, water quality, and water-supply potential of ponds at Hunter Army Airfield, Chatham County, Georgia, November 2008-July 2009: U.S. Geological Survey Scientific Investigations Report 2009-5265, 34 p. 


\section{Contents}

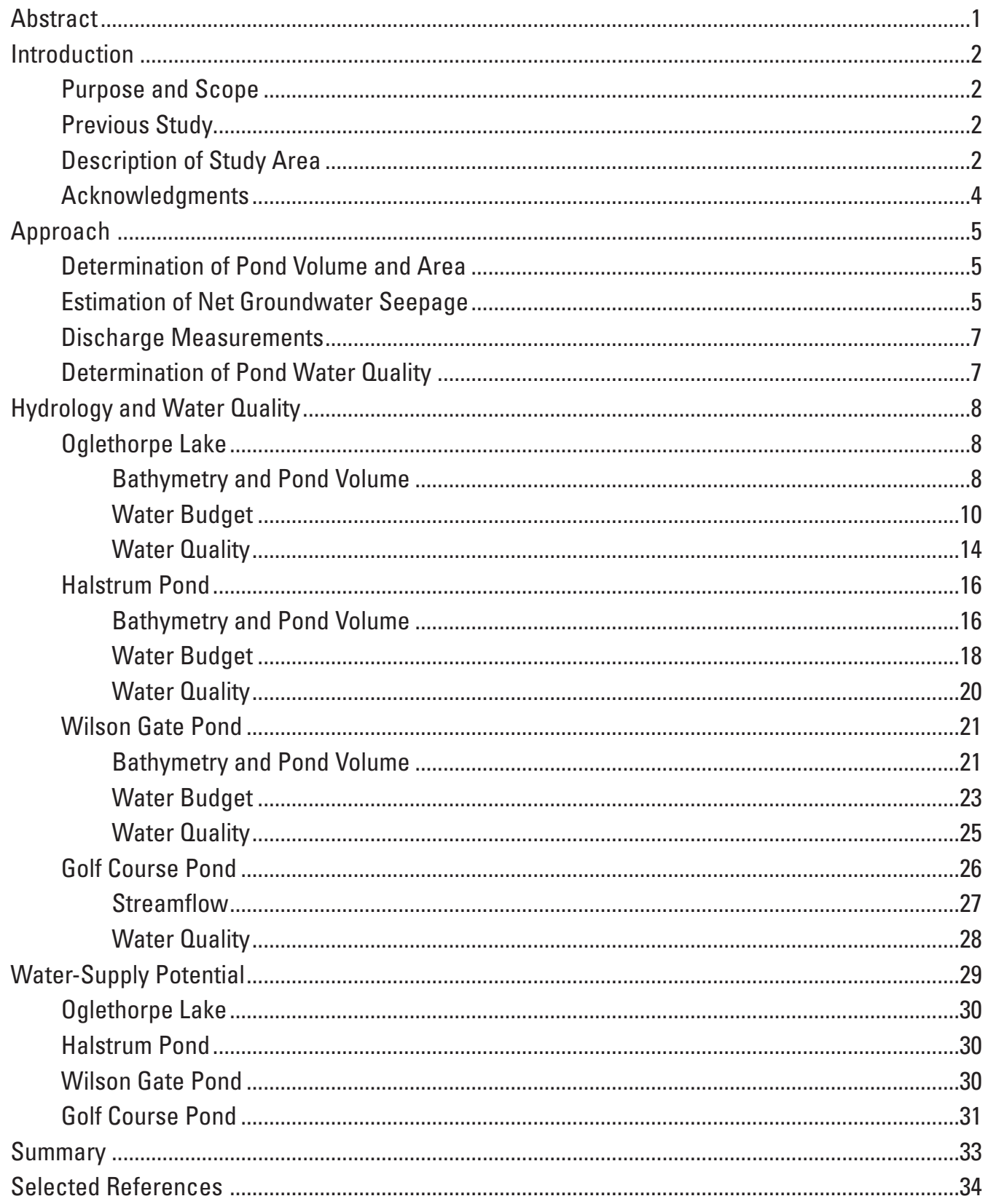




\section{Figures}

1. Map showing location of selected ponds in the Hunter Army Airfield area, Chatham County, Georgia.....

2-3. Graphs showing-

2. Mean monthly precipitation and mean monthly pan evaporation at National Weather Service Station 097847, Savannah International Airport, Georgia . .4

3. Total monthly precipitation and cumulative departure from normal precipitation at National Weather Service Station 097847, Savannah International Airport, Georgia, 2005-2009..

4. Diagram showing conceptual model of pond-aquifer flow for coastal area seepage ponds

5. Image showing Oglethorpe Lake, Hunter Army Airfield, Chatham County, Georgia .........8

6. Map showing bathymetry of Oglethorpe Lake, Hunter Army Airfield, Chatham County, Georgia, December 2008 and April 2009.

7-9. Graphs showing-

7. Stage and total daily precipitation at Oglethorpe Lake, Hunter Army Airfield, Chatham County, Georgia, November-December 2008.

8. Relation of pond stage to computed volume and surface area, and regression fit of data, Oglethorpe Lake, Hunter Army Airfield, Chatham County, Georgia.

9. Hydrologic and climatic data at Oglethorpe Lake, Hunter Army Airfield, Chatham County, Georgia, and vicinity, November-December 2008: Daily precipitation and net precipitation at Oglethorpe Lake, and estimated daily evapotranspiration at the Bamboo Farm, Georgia Environmental Monitoring Site; net groundwater seepage; pond stage; and cumulative daily pond discharge.

10-11. Photographs showing

10. Dam leakage at Oglethorpe Lake, Hunter Army Airfield, Chatham County, Georgia, November 2008

11. Oglethorpe Lake on December 3, 2008, after stage lowered by 1.42 feet

12-14. Graphs showing-

12. Daily average pond discharge at Oglethorpe Lake, Hunter Army Airfield, Chatham County, Georgia, November 7-December 31, 2008.

13. Cumulative daily change in pond volume, discharge, net precipitation, and net groundwater seepage, Oglethorpe Lake, Hunter Army Airfield, Chatham County, Georgia, November-December 2008.

14. Water-quality profile at Oglethorpe Lake, Hunter Army Airfield, Chatham County, Georgia, April 22, 2009

15. Image showing Halstrum Pond, Hunter Army Airfield, Chatham County, Georgia ..........16

16. Photograph showing Halstrum Pond looking westward toward earthen dam, Hunter Army Airfield, Chatham County, Georgia

17. Map showing bathymetry of Halstrum Pond, Hunter Army Airfield, Chatham County, Georgia, December 2008.

18-22. Graphs showing-

18. Stage and daily total precipitation at Halstrum Pond, Hunter Army Airfield, Chatham County, Georgia, November-December 2008. 18

19. Relation of pond stage to computed volume and surface area, and regression fit of data, Halstrum Pond, Hunter Army Airfield, Chatham County, Georgia 
20. Hydrologic and climatic data at Halstrum Pond, Hunter Army Airfield,

Chatham County, Georgia, and vicinity, November-December 2008: Daily

precipitation and net precipitation at the Halstrum Pond, and estimated

daily evapotranspiration at the Bamboo Farm, Georgia Environmental

Monitoring Site; net groundwater seepage; pond stage; and cumulative

daily pond discharge.

21. Cumulative daily change in pond volume and discharge and net precipitation and net groundwater seepage, Halstrum Pond, Hunter

Army Airfield, Chatham County, Georgia, November-December 2008

22. Water-quality profile at Halstrum Pond, Hunter Army Airfield,

Chatham County, Georgia, April 21, 2009 . .20

23. Image showing Wilson Gate pond, Hunter Army Airfield, Chatham County, Georgia ....21

24. Photograph showing Wilson Gate pond from top of earthen dam looking westward, Hunter Army Airfield, Chatham County, Georgia

25. Map showing bathymetry of Wilson Gate Pond, Hunter Army Airfield, Chatham County, Georgia, December 2008

26-30. Graphs showing-

26. Stage and estimated daily total precipitation at Wilson Gate Pond, Hunter

Army Airfield, Chatham County, Georgia, November-December 2008

27. Relation of pond stage to computed volume and surface area, and regression fit of data, Wilson Gate Pond, Hunter Army Airfield, Chatham County, Georgia

28. Hydrologic and climatic data at Wilson Gate Pond, Hunter Army Airfield, Chatham County, Georgia, and vicinity, November-December 2008: Daily estimated precipitation and net precipitation at Halstrum Pond, and estimated daily evapotranspiration at the Bamboo Farm, Georgia Environmental Monitoring Site; net groundwater seepage; and pond stage

29. Cumulative daily change in pond volume, net precipitation, and net groundwater seepage, Wilson Gate Pond, Hunter Army Airfield, Chatham County, Georgia, November-December 2008.

30. Water-quality profile at Wilson Gate Pond, Hunter Army Airfield, Chatham County, Georgia, April 21, 2009.

31. Image showing golf course pond, Hunter Army Airfield, Chatham County, Georgia ......26

32. Photograph showing weir at golf course pond Hunter Army Airfield,

Chatham County, Georgia.

33-34. Graphs showing-

33. Periodic streamflow at site 02203542, Harmon Canal, Hunter Army Airfield, Chatham County, Georgia, 1979-87. .27

34. Hourly streamflow at golf course pond, Hunter Army Airfield,

Chatham County, Georgia, February-July 2009.

35-37. Graphs showing hypothetical rate of depletion of pond volume at pumping rates of $1,000,500$, and 250 gallons per minute for 8 hours per day for long-term climatic conditions during July at-

35. Oglethorpe Lake, Hunter Army Airfield, Chatham County, Georgia . .30

36. Halstrum Pond, Hunter Army Airfield, Chatham County, Georgia

37. Wilson Gate Pond, Hunter Army Airfield, Chatham County, Georgia . .30

38. Graphs showing average daily golf course water use, 2005-07, periodic streamflow measurements during 1979-87, and average daily streamflow during MarchJuly 2009, golf course pond, Hunter Army Arifield, Chatham County, Georgia .. 


\section{Tables}

1. Water quality analysis of ponds at Hunter Army Airfield, Chatham County, Georgia, April 2009

2. Statistical summary of streamflow data at golf course pond, Hunter Army Airfield, Chatham County, Georgia, 1979-87 and 2009.

3. Summary of pond volume and net groundwater seepage and pond-volume depletion rates for Oglethorpe Lake and Halstrum and Wilson Gate Ponds, Hunter Army Airfield, Chatham County, Georgia.....

4. Water use at golf course, Hunter Army Airfield, 2005-07. 


\section{Conversion Factors and Datums}

\begin{tabular}{|c|c|c|}
\hline Multiply & By & To obtain \\
\hline \multicolumn{3}{|c|}{ Length } \\
\hline inch & 2.54 & centimeter $(\mathrm{cm})$ \\
\hline inch & 25.4 & millimeter $(\mathrm{mm})$ \\
\hline foot $(\mathrm{ft})$ & 0.3048 & meter $(\mathrm{m})$ \\
\hline mile (mi) & 1.609 & kilometer (km) \\
\hline \multicolumn{3}{|c|}{ Area } \\
\hline acre & 4,047 & square meter $\left(\mathrm{m}^{2}\right)$ \\
\hline acre & 0.4047 & hectare (ha) \\
\hline acre & 0.4047 & square hectometer $\left(\mathrm{hm}^{2}\right)$ \\
\hline acre & 0.004047 & square kilometer $\left(\mathrm{km}^{2}\right)$ \\
\hline square foot $\left(\mathrm{ft}^{2}\right)$ & 929.0 & square centimeter $\left(\mathrm{cm}^{2}\right)$ \\
\hline square foot $\left(\mathrm{ft}^{2}\right)$ & 0.09290 & square meter $\left(\mathrm{m}^{2}\right)$ \\
\hline square mile $\left(\mathrm{mi}^{2}\right)$ & 259.0 & hectare (ha) \\
\hline square mile $\left(\mathrm{mi}^{2}\right)$ & 2.590 & square kilometer $\left(\mathrm{km}^{2}\right)$ \\
\hline \multicolumn{3}{|c|}{ Volume } \\
\hline gallon (gal) & 3.785 & liter $(\mathrm{L})$ \\
\hline gallon (gal) & 0.003785 & cubic meter $\left(\mathrm{m}^{3}\right)$ \\
\hline gallon (gal) & 3.785 & cubic decimeter $\left(\mathrm{dm}^{3}\right)$ \\
\hline million gallons (Mgal) & 3,785 & cubic meter $\left(\mathrm{m}^{3}\right)$ \\
\hline \multicolumn{3}{|c|}{ Flow rate } \\
\hline cubic foot per second $\left(\mathrm{ft}^{3} / \mathrm{s}\right)$ & 0.02832 & cubic meter per second $\left(\mathrm{m}^{3} / \mathrm{s}\right)$ \\
\hline gallon per minute (gal/min) & 0.06309 & liter per second $(\mathrm{L} / \mathrm{s})$ \\
\hline gallon per day (gal/d) & 0.003785 & cubic meter per day $\left(\mathrm{m}^{3} / \mathrm{d}\right)$ \\
\hline million gallons per day (Mgal/d) & 0.04381 & cubic meter per second $\left(\mathrm{m}^{3} / \mathrm{s}\right)$ \\
\hline inch per year (in/yr) & 25.4 & millimeter per year (mm/yr) \\
\hline
\end{tabular}

Temperature in degrees Celsius $\left({ }^{\circ} \mathrm{C}\right)$ may be converted to degrees Fahrenheit $\left({ }^{\circ} \mathrm{F}\right)$ as follows:

$$
{ }^{\circ} \mathrm{F}=\left(1.8 \times{ }^{\circ} \mathrm{C}\right)+32
$$

Temperature in degrees Fahrenheit $\left({ }^{\circ} \mathrm{F}\right)$ may be converted to degrees Celsius $\left({ }^{\circ} \mathrm{C}\right)$ as follows:

$$
{ }^{\circ} \mathrm{C}=\left({ }^{\circ} \mathrm{F}-32\right) / 1.8
$$

Vertical coordinate information is referenced to the North American Vertical Datum of 1988 (NAVD 88).

Horizontal coordinate information is referenced to North American Datum of 1983 (NAD 83).

Altitude, as used in this report, refers to distance above the vertical datum.

Specific conductance is given in microsiemens per centimeter at 25 degrees Celsius $(\mu \mathrm{S} / \mathrm{cm}$ at $\left.25^{\circ} \mathrm{C}\right)$.

Concentrations of chemical constituents in water are given either in milligrams per liter ( $\mathrm{mg} / \mathrm{L}$ ) or micrograms per liter $(\mu \mathrm{g} / \mathrm{L})$. 


\title{
Hydrology, Water Quality, and Water-Supply Potential of Ponds at Hunter Army Airfield, Chatham County, Georgia, November 2008-July 2009
}

\author{
By John S. Clarke and Jaime A. Painter
}

\section{Abstract}

The hydrology, water quality, and water-supply potential of four ponds constructed to capture stormwater runoff at Hunter Army Airfield, Chatham County, Georgia, were evaluated as potential sources of supplemental irrigation supply. The ponds are, Oglethorpe Lake, Halstrum Pond, Wilson Gate Pond, and golf course pond. During the dry season, when irrigation demand is highest, ponds maintain water levels primarily from groundwater seepage. The availability of water from ponds during dry periods is controlled by the permeability of surficial deposits, precipitation and evaporation, and the volume of water stored in the pond. Net groundwater seepage (Gnet) was estimated using a waterbudget approach that used onsite and nearby climatic and hydrologic data collected during November-December 2008 including precipitation, evaporation, pond stage, and discharge.

Gnet was estimated at three of the four sites-Oglethorpe Lake, Halstrum Pond, and Wilson Gate Pond-during November-December 2008. Pond storage volume in the three ponds ranged from 5.34 to 12.8 million gallons. During November-December 2008, cumulative Gnet ranged from -5.74 gallons per minute ( $\mathrm{gal} / \mathrm{min})$, indicating a net loss in pond volume, to $19 \mathrm{gal} / \mathrm{min}$, indicating a net gain in pond volume. During several periods of stage recovery, daily Gnet rates were higher than the 2-month cumulative amount, with the highest rates of 178 to $424 \mathrm{gal} / \mathrm{min}$ following major rainfall events during limited periods. These high rates may include some contribution from stormwater runoff; more typical recovery rates were from 23 to $223 \mathrm{gal} / \mathrm{min}$.

A conservative estimate of the volume of water available for irrigation supply from three of the ponds was provided by computing the rate of depletion of pond volume for a variety of withdrawal rates based on long-term average July precipitation and evaporation and the lowest estimated
Gnet rate at each pond. Withdrawal rates of 1,000, 500, and $250 \mathrm{gal} / \mathrm{min}$ were applied during an 8-hour daily pumping period. At a withdrawal rate of $1,000 \mathrm{gal} / \mathrm{min}$, available pond volume would be depleted in 13-29 days, at a rate of $500 \mathrm{gal} / \mathrm{min}$ in 24-60 days, and at a rate of $250 \mathrm{gal} / \mathrm{min}$, in 44 to 130 days. In each case, Halstrum Pond had the largest amount of available pond volume.

The water-supply potential at the golf course pond was assessed by measuring flow downstream from the pond during February-July 2009, and examining historic stormflow measurements collected during 1979-87. Streamflow during both of these periods exceeded average daily (2005-2007) golf course water use. Assuming an 8-hour daily irrigation period, the average discharge rate required to meet Golf Course water demand during peak demand months of March-May and July-October exceeds $200 \mathrm{gal} / \mathrm{min}$, with the greatest rate of $531 \mathrm{gal} / \mathrm{min}$ during July. During February-July 2009, daily average streamflow downstream of the golf course pond exceeded $238 \mathrm{gal} / \mathrm{min} 90$ percent of the time.

Based on samples collected for chemical analysis during April 2009, water from all four ponds at Hunter Army Airfield is fresh and suitable for irrigation supply, with chloride concentrations below 12 milligrams per liter. With the exception of iron in Wilson Gate Pond, constituent concentrations are below U.S. Environmental Protection Agency primary and secondary drinking water maximum contaminant levels. Water in Wilson Gate Pond contained an iron concentration of $419 \mathrm{mg} / \mathrm{L}$, which exceeds the secondary maximum contaminant level of 300 micrograms per liter. Although not a health hazard, when the iron concentration exceeds 300 micrograms per liter, iron staining of sidewalks and plumbing fixtures may occur. Levels of dissolved oxygen were below the Georgia Environmental Protection Divison standard of 4 milligrams per liter for waters supporting warm-water fishes at deeper depths in Oglethorpe Lake, Wilson Gate Pond, and Halstrum Pond, and in the composite sample at the golf course pond. 


\section{Introduction}

The Upper Floridan aquifer is the principal source of water in the coastal area of Georgia, but declining water levels and localized occurrences of salt-water contamination have resulted in restricted ("capped") withdrawals from the Upper Floridan aquifer in parts of the coastal area and have spurred interest in developing supplemental sources of water. To meet the growing water demand at Hunter Army Airfield (HAAF) in Chatham County, Georgia, four ponds-Oglethorpe Lake, Halstrum Pond, Wilson Gate Pond, and golf course pondare being considered as possible sources of supplemental irrigation supply (fig. 1). To assess the water-supply potential and water quality of these ponds, the U.S. Geological Survey (USGS), in cooperation with the U.S. Department of the Army, conducted field investigations during November 2008July 2009.

\section{Purpose and Scope}

This report describes results of investigations to evaluate the water-supply potential at pond sites at HAAF, Georgia. Included are

- Descriptions of local site setting and pond bathymetry;

- Estimates of the volume of water stored in Oglethorpe Lake, and Halstrum and Wilson Gate Ponds over a range of stages;

- Estimates of net groundwater seepage derived from water-budget analyses and pond-discharge tests for Oglethorpe Lake, and Halstrum, and Wilson Gate Ponds under dry climatic conditions;

- Estimated flow rates downstream from the discharge weir at golf course pond; and

- Determination of suitability of pond water quality for irrigation purposes.

Data collection included installation of stage recorders in Oglethorpe Lake, and Halstrum and Wilson Gate Ponds, and in the canal draining the golf course pond. Precipitation was monitored using new raingages installed at Ogtlethorpe Lake and Halstrum Pond, and existing raingages used for stormwater monitoring at Wilson Gate and golf course ponds. Evaporation estimates were obtained from an existing Georgia Automated Environmental Monitoring Network (GaEMN) site, the Bamboo Farm in Chatham County, about 8-9 miles to the west of the study area (Georgia Automated Environmental Monitoring Network, 2009). Stream-discharge measurements were made over a range of conditions to establish a stagedischarge rating at the golf course pond drainage canal. Water samples were collected and analyzed for major ions and nutrients from each of the four ponds during April 2009.

\section{Previous Study}

Clarke and Abu Rumman (2004) described results of investigations to evaluate the water-supply potential at seepage pond sites at Brunswick, in Glynn County, and in southern Bulloch County, Georgia. This study included descriptions of the hydrogeologic setting, estimates of a hydrologic budget and groundwater seepage rates, development and calibration of steady-state and transient groundwater flow models, and an assessment of water availability based on pond pumping tests and simulation results. Their study concluded that the availability of water from seepage ponds is controlled by the permeability of surficial deposits, the amount of precipitation recharging the groundwater system, and the volume of water stored in the pond. At both sites, most groundwater seepage entered the pond following major rainfall events that provided recharge to the surficial aquifer. The ponds at HAAF are located in a setting similar to the Glynn County site. At the Glynn County site, Clarke and Abu Rumman (2004) reported that net groundwater seepage, estimated using water-budget analysis and simulation, ranged from -11.5 to 15 gallons per minute (gal/min) during August 1999 to May 2000. Simulated values during pond pumping tests indicate that groundwater seepage increases with decreased pond stage. At the Glynn County pond, simulated net groundwater seepage increased from 7.8 to $103 \mathrm{gal} / \mathrm{min}$ in response to a 2 -foot (ft) decrease in pond stage caused by pumping.

\section{Description of Study Area}

HAAF is located in western Chatham County, Georgia (fig. 1), in the Coastal Lowlands physiographic division (LaForge and others, 1925), near the Atlantic Ocean, in an area characterized by low relief and high-permeability sandy soils. Sandy soils compose the surficial aquifer, which is recharged by precipitation and discharges water to ponds, wetlands, and surface streams in the area. During dry periods, excavated ponds, such as those at HAAF, derive water primarily from groundwater seeping into the pond, in a manner similar to a dug or bored well completed in a surficial aquifer.

Four ponds constructed to capture stormwater runoff at HAAF were evaluated as potential sources of supplemental irrigation supply - Oglethorpe Lake, Halstrum Pond, Wilson Gate Pond, and golf course pond (fig. 1). Oglethorpe Lake, and Halstrum and Wilson Gate Ponds range in area from 4.6 to 9.5 acres, and in maximum depth from about 6 to $16 \mathrm{ft}$. Area and depth of the golf course pond were not delineated because streamflow records were used as a basis for evaluation and a detailed water budget analysis was not required. More detailed descriptions of individual ponds are provided in later sections of the report.

The study area has a mild climate with warm, humid summers and mild winters. Long-term climatic patterns in the area are provided by records from the National Weather Service Station at Savannah International Airport (097847). 


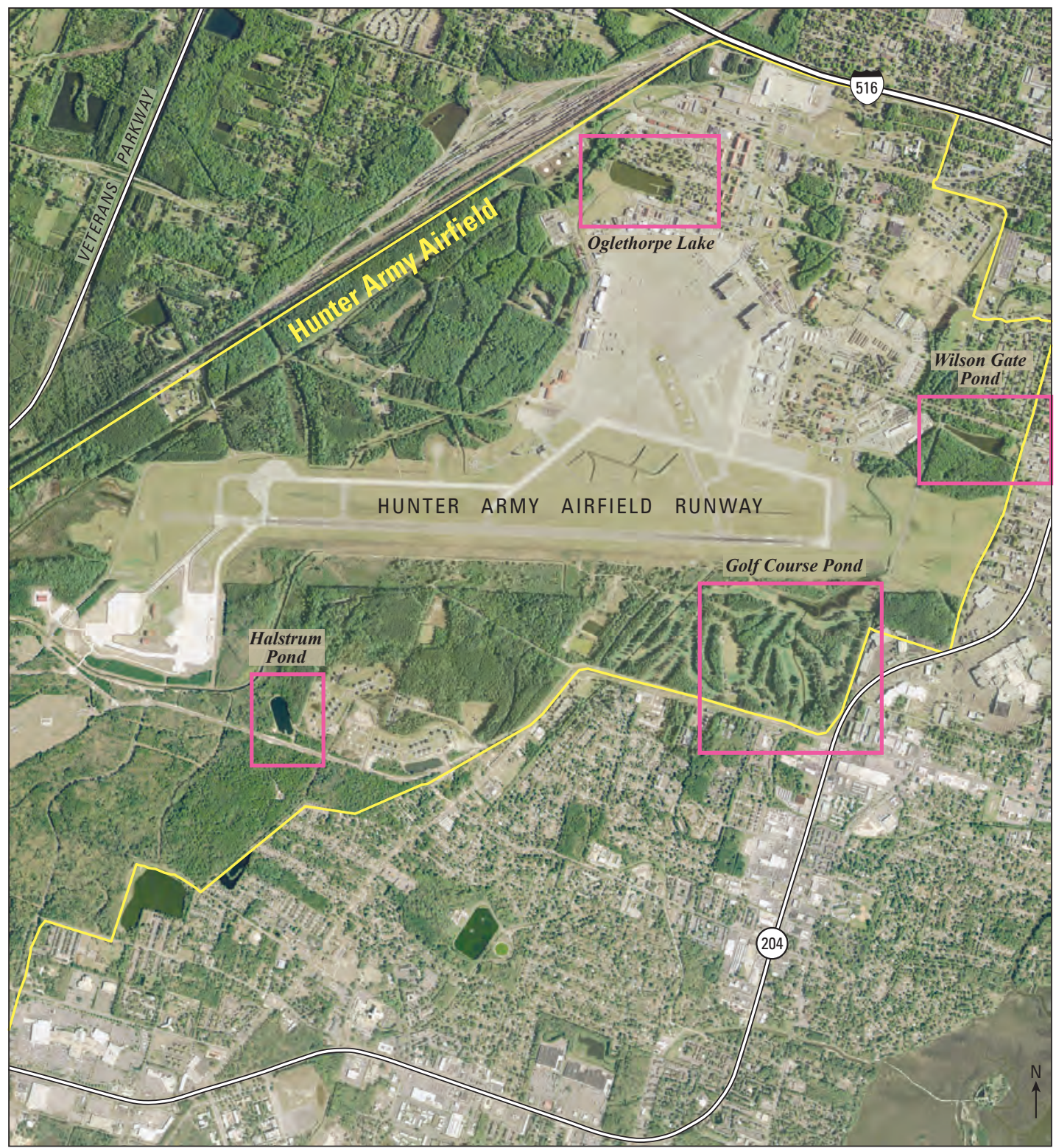

Modified from U.S. Geological Survey Coastal Imagery 0.5-meter resolution, 2006
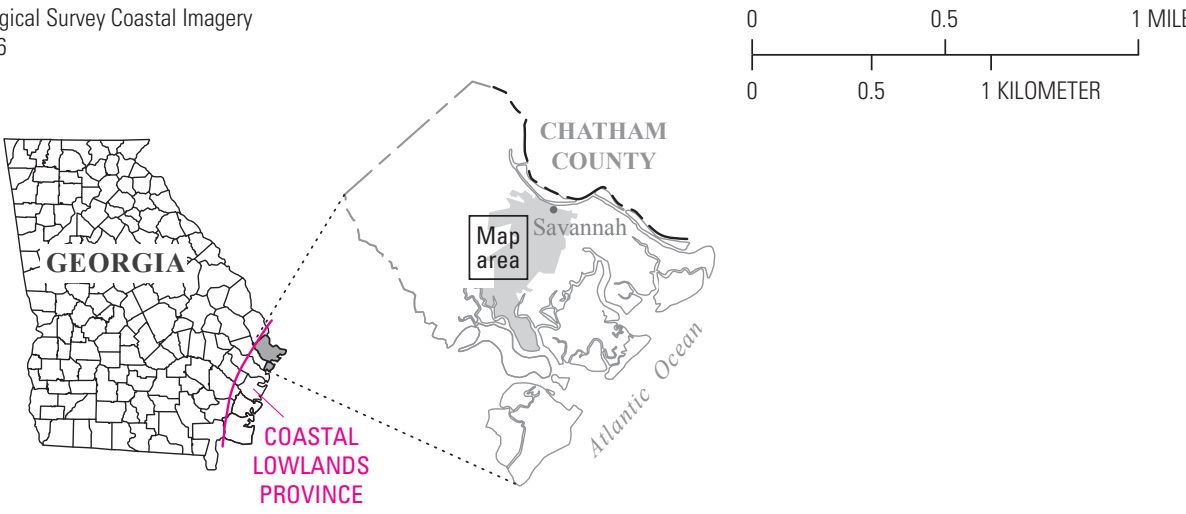

Figure 1. Location of selected ponds in the Hunter Army Airfield area, Chatham County, Georgia. 
During 1971-2000, precipitation at station 097847 averaged about 49 inches per year (in/yr). Maximum monthly rainfall (exceeding 4 inches per month) generally occurs during June-September, with monthly rainfall totals averaging less than 4 inches during the rest of the year (fig. 2). Mean monthly pan evaporation at station 097847 during 1965-2003 ranged from 2.43 to 8.49 inches per month, with the greatest evaporation during April-August. Monthly total precipitation and

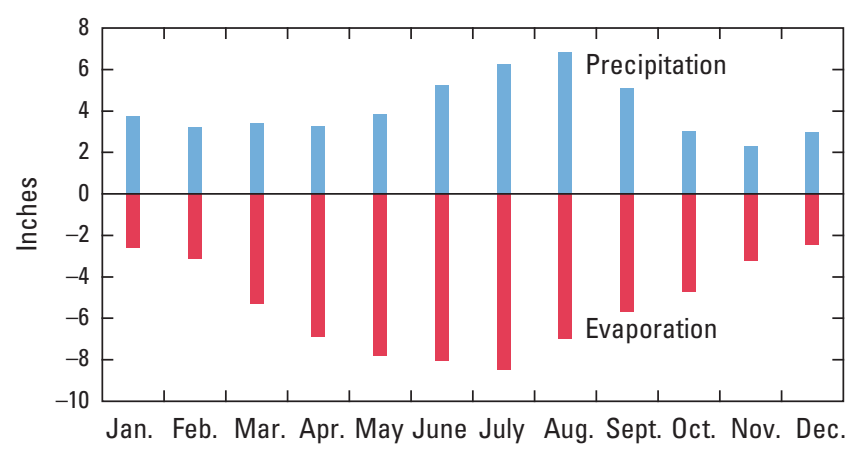

Figure 2. Mean monthly precipitation (1971-2000) and mean monthly pan evaporation (1965-2003) at National Weather Service Station 097847, Savannah International Airport, Georgia. the cumulative departure from long-term average or "normal" precipitation for January 2005-May 2009 at station 097847 is shown in figure 3. Precipitation data indicate that pond water-budget evaluations at HAAF were conducted during a period of largely above-normal precipitation in NovemberDecember 2008, after a period of below-normal precipitation during January-September 2008.

\section{Acknowledgments}

The authors appreciate the assistance of the U.S. Department of the Army and its contractors for providing onsite support and data. Special thanks to Eric Stulpin, Stanley Thomas, Tressa Williams, and Nathaniel Williams, II, of the U.S. Army Environmental Protection and Compliance Branch. Rachael Hallman, U.S. Army Fish and Wildlife Branch, provided support in measuring pond bathymetry and releasing water from ponds.

Michael Hamrick, Gary Holloway, Mark Truhlar, and Welby L. Stayton of the U.S. Geological Survey, provided valuable assistance in site setup and monitoring hydrologic conditions. John K. Joiner and Anthony J. Gotvald, of the U.S. Geological Survey, computed the stage-discharge rating at the golf course pond.
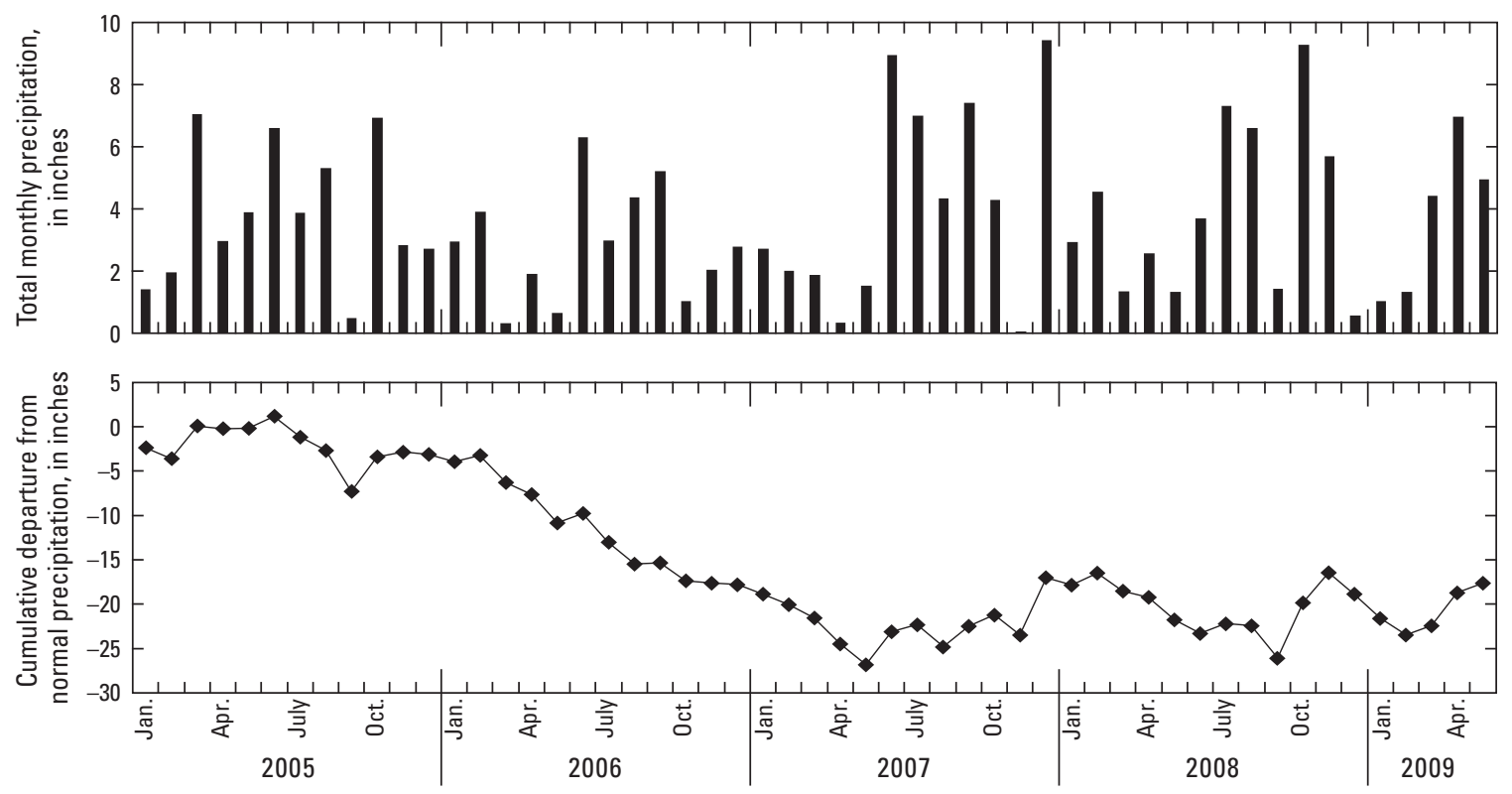

Figure 3. Total monthly precipitation and cumulative departure from normal (1971-2000) precipitation at National Weather Service Station 097847, Savannah International Airport, Georgia, 2005-2009. 


\section{Approach}

This study investigated water availability and water quality at four pond sites at HAAF, which included:

- Determination of the volume of water stored in Oglethorpe Lake, Halstrum Pond, and Wilson Gate Pond under a range of stage conditions;

- Measurement of streamflow discharging from the golf course pond and development of a stagedischarge relation to determine flow rates over a range of climatic conditions;

- Estimating net groundwater seepage by developing hydrologic budgets for Oglethorpe Lake and Halstrum and Wilson Gate Ponds; and

- Sampling and analysis for pond water quality.

\section{Determination of Pond Volume and Area}

Digital maps of pond bathymetry in Oglethorpe Lake, and Halstrum and Wilson Gate Ponds were developed based on bathymetric surveys conducted during December 2008 and April 2009 by the USGS. Bathymetric surveys were conducted using a fathometer linked to a global positioning system with horizontal accuracy of 11-13 ft and depth accuracy of at least 1 centimeter ( 0.39 inch). Point data were imported into ArcMap $^{\mathrm{TM}}$ and converted into a point feature dataset. Upon spatial review of bathymetric depths, some discrepancies in the pond floor were apparent in certain areas. These discrepancies were possibly due to the fathometer signal being interrupted by a tree stump, resulting in significant variation in depths among adjacent data points (in some case $1 \mathrm{ft}$ or more.) Because of the high frequency of fathometer soundings and the belief that a subset of the data would eliminate many of these depth discrepancies, a subset of fathometer soundings was derived using the ArcGIS ${ }^{\text {TM }}$ Geostatistical Analyst tool, "Create Subsets." This subset routine uses a random sample of the dataset based on a user-designated percentage criteria. For this study, a 50-percent criterion was designated whereby one-half of the fathometer measurements were used for the bathymetric surface generation at the three ponds.

Bathymethric surfaces were generated by using the ArcGISTM 3D Analyst raster interpolation, "Spline with Barriers" tool. This tool allowed the generated raster to be restricted to the pond perimeter. The cell size used for contouring was 1 meter by 1 meter ( 3.21 by $3.21 \mathrm{ft}$ ); contours were generated at a 1-ft interval. Once a surface was generated using the subset of field measurements, the surface was compared to the entire dataset and minor manual modifications were made.
To calculate and project pond volume and surface area for a range of pond stages, a triangulated irregular network (TIN) was generated using the bathymetric contours. The ArcGISTM 3D Analyst, Functional Surface, "Surface Volume" tool takes the altitude TIN and examines each individual triangle to determine its contribution to the area and volume. The tool requires the input of the elevation TIN along with user decisions to calculate below or above a defined reference plane or altitutde. The results are written to a text file. These data, computed using the geographic information system (GIS) for selected stage values, served as a basis to determine continuous relations between pond stage and volume using a second- or third-order polynomial regression of pond stage and pond volume. Similarly, relations between pond stage and surface area were developed using a second-order polynomial regression of pond stage and pond area. Changes in pond volume and surface area were computed by comparing values at different pond stages.

\section{Estimation of Net Groundwater Seepage}

The water-supply potential of a pond is dependent on the volume of water stored in the pond, precipitation and evaporation, surface-water runoff, and the rate of groundwater seepage into the pond. Figure 4 is a schematic diagram showing a conceptualization of groundwater flow and components of the water budget in the vicinity of a typical pond at HAAF. Groundwater seepage represents water either entering or leaving a pond as the result of hydraulic gradients between the aquifer and the pond. Net groundwater seepage (Gnet) is the difference between groundwater inflow minus outflow-when positive, more groundwater enters than leaves the pond; when negative, more groundwater leaves than enters the pond (Clarke and Abu Rumman, 2004). Rates and directions of groundwater seepage vary depending on groundwater levels and pond stage and related changes in hydraulic gradient and cross-sectional area. Decreased pond stage or increased groundwater levels result in an increased hydraulic gradient toward the pond and increased rates of seepage to the pond. Increased pond stage results in a decreased or reversed hydraulic gradient, whereby seepage to the pond is either decreased or reversed.

A simplified hydrologic budget for three ponds was developed to estimate Gnet and provide an indication of the volume of water available for irrigation during dry periods. The water budget used measurements of precipitation, evaporation, pond discharge, and pond-volume changes to estimate Gnet. A pond hydrologic budget was developed based on daily data using equation 1 (modified from Clarke and Abu Rumman, 2004): 


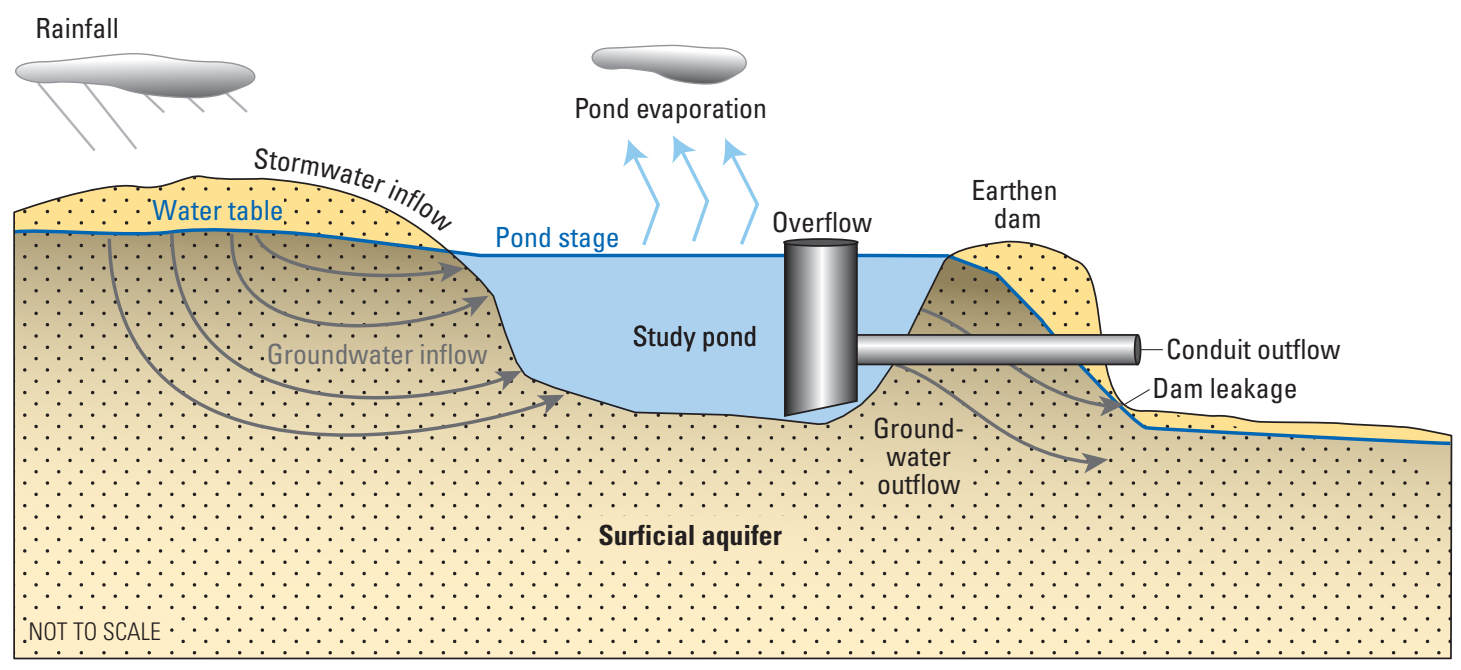

Figure 4. Conceptual model of pond-aquifer flow for coastal area seepage ponds.

$$
\text { Gnet }=\Delta \mathrm{V}+\mathrm{E}-\mathrm{P}-\mathrm{S}+\mathrm{Q} \pm \varepsilon,
$$

where

$$
\begin{gathered}
\Delta \mathrm{V} \quad \text { is the daily pond volume change, in } \\
\text { million gallons, } \\
\mathrm{E} \quad \begin{array}{c}
\text { is daily evaporation from the pond, in } \\
\text { million gallons, }
\end{array} \\
\mathrm{P} \quad \begin{array}{c}
\text { is daily precipitation falling over the } \\
\text { pond, in million gallons, }
\end{array} \\
\mathrm{S} \quad \begin{array}{c}
\text { is daily surface-water runoff, in million } \\
\text { gallons (assumed 0, see below), }
\end{array} \\
\mathrm{Q} \quad \text { is daily discharge and pond leakage, } \\
\text { in million gallons, and } \\
\varepsilon \quad \text { is the error associated with the estimate. }
\end{gathered}
$$

Surface-water runoff was considered negligible due to permeable soils and low relief, and because the study was conducted during a mostly dry period. Volumetric estimates of precipitation and evaporation were computed by multiplying total daily precipitation or evaporation (in volume per unit surface area) by pond surface area.

Evaporation estimates were based on evapotranspiration computed at an existing GaEMN site, Bamboo Farm, in Chatham County, about 8-9 miles to the west of the study area (Georgia Automated Environmental Network, 2009). Sensors at this weather station measure air temperature, relative humidity, wind speed and direction, net and total solar radiation, barometric pressure, precipitation, and soil temperature at 2-, 4-, and 8-inch depths. GaEMN estimates potential evapotranspiration from these data using the Priestley-Taylor method (Stewart and Rouse, 1976).
To induce a change in pond stage and assess higher rates of Gnet when there is a larger hydraulic gradient between the surficial aquifer and the pond (Clarke and Abu Rumman, 2004), water was released (discharged) from Halstrum Pond and Oglethorpe Lake. To lower stage, water was discharged from the dam gate valve to a downstream location where infiltration did not affect test results.

Quantification of measurement errors of each waterbudget component provides a measure of the reliability or accuracy of the hydrologic budget as a predictive tool (Lee and Swancar, 1997). Field measurements have an associated error depending on the method of measurement. Because Gnet is estimated from several different types of field measurements, the total error associated with its estimation is an accumulation of errors of the various measurements. The error ( $\varepsilon$ ) for Gnet can be described using the following equation (Lee and Swancar, 1997) that accounts for percentage error of each parameter used in the computation:

$$
\begin{aligned}
\varepsilon_{\text {Gnet }}= & \sqrt{ }\left[(\% \varepsilon \mathrm{P} \times \mathrm{P})^{2}+(\% \varepsilon \mathrm{E} \times \mathrm{E})^{2}+\right. \\
& \left.(\% \varepsilon \mathrm{V} \times \mathrm{V})^{2}+(\% \mathrm{QV} \times \mathrm{Q})^{2}\right],
\end{aligned}
$$

where

$$
\begin{array}{cl}
\varepsilon_{G n e t} & \text { is the error in Gnet in million gallons, } \\
\% \varepsilon \mathrm{P} & \text { is the percentage error in precipitation, } \\
\% \varepsilon \mathrm{E} & \text { is the percentage error in evaporation, } \\
\% \varepsilon \mathrm{V} & \text { is the percentage error in pond volume, } \\
\% \mathrm{QV} & \text { is the percentage error in discharge, and } \\
\mathrm{P}, \mathrm{E}, \mathrm{V}, \text { and } \mathrm{Q} & \text { are as defined for equation } 1 .
\end{array}
$$


Pond volume changes were assigned a 5-percent error, and precipitation was assigned a 15 -percent error based on a study by Winter (1981). At Wilson Gate Pond, an additional 5-percent error was added to precipitation values (total error 20 percent) because part of the data was estimated based on a regression analysis. Pond discharge was assigned an error of 10 percent at each of the ponds, with the exception of Oglethorpe Lake, which was assigned an error of 25 percent because of leakage through the earthen dam. An additional source of error is any water contributed to the pond by stream runoff, which could lead to large Gnet values during rainfall periods.

Errors associated with evaporation estimates are difficult to quantify. Factors affecting the accuracy of the estimate include the distance of the GaEMN site from HAAF (8-9 miles), and the method used to estimate evapotranspiration by GaEMN. Mosner and Aulenbach (2003) conducted an assessment of methods used to estimate evapotranspiration at Lake Seminole in southwestern Georgia. Mosner and Aulenbach (2003) compared four methods used to estimate evaporation-including the Priestley-Taylor method used by the GaEMN to estimate evapotranspiration for this studyto the energy budget method, which is recognized as the one of the most accurate methods for determining lake evaporation (Winter, 1981). Their study concluded that estimates computed using the Priestley-Taylor method as computed by the GaEMN were generally lower than values computed using the energybudget method, with an average error of -18.7 percent, and monthly errors ranging from -83.2 to +0.5 percent. Errors were largest during September-March, with a mean error of 46.5 percent. Because studies at HAAF were conducted during the winter months, an error of 50 percent was assumed for evaporation estimates. Fortunately, evaporation was low during the study period (fig. 2), so the influence of such a large error factor on estimation of Gnet was minimal.

\section{Discharge Measurements}

Pond discharge was measured using a circular orifice weir at Halstrum Pond, and by making stream-discharge measurements using a Price AA current meter at Oglethorpe Lake. A continuous stream stage recorder was installed in the drainage canal downstream from the discharge weir at the golf course pond to enable estimation of stream discharge. Streamdischarge measurements at this site were taken over a range of stage conditions to develop a best-fit line or "rating" based on visual examination of stage-discharge data using procedures described in Rantz and others (1982).

\section{Determination of Pond Water Quality}

Water samples were collected from each of the four pond sites in April 2009 to assess basic water quality. At Oglethorpe Lake, Halstrum Pond, and Wilson Gate Pond, field properties - dissolved oxygen, temperature, specific conductance, and $\mathrm{pH}$ - were measured at several depths at the deepest part of each pond to determine if there was stratification of the water column. Based on these profiles, samples were collected from the pond at several depths and mixed together using a churn splitter. At the golf course pond, a water sample was collected at a weir, which is the point of discharge from the pond. Water samples were analyzed for major ions and nutrients. These samples represent the non-storm water-quality condition of the ponds. Because the ponds also serve to capture runoff from HAAF during storm events, it is likely that the quality of water changes during such storms. 


\section{Hydrology and Water Quality}

The hydrology of seepage ponds - including rates of net precipitation (Pnet) and Gnet and the volume of water stored in the pond - determines the amount of water available for water supply. In addition, suitability of pond water for irrigation purposes may be limited by the quality of water. The following sections describe the bathymetry, water budget, and water quality of seepage ponds located at HAAF.

\section{Oglethorpe Lake}

Oglethorpe Lake, also known as pond 29, was constructed in 1985 and covers a 9.5-acre area underlain by sandy soils (fig. 5). The pond is used to capture stormwater and also is used as a fishing pond. The pond, excavated to a maximum depth of about $9 \mathrm{ft}$, is contained by an earthen dam and captures runoff from Hickam Boulevard, Douglas Street, and Strachan Avenue. Stormwater enters the pond along the eastern shore from a ditch perpendicular to Douglas Street.
After periods of prolonged, heavy rainfall, water discharges from the pond through an overflow culvert into a ditch along the western shore, downstream from the dam. Field studies at Oglethorpe Lake were conducted during November 7December 31, 2008.

\section{Bathymetry and Pond Volume}

Bathymetric surveys conducted on December 3, 2008, and April 22, 2009, indicate that the altitude of the bottom of Oglethorpe Lake ranges from about 14 to $21 \mathrm{ft}$ above the North American Vertical Datum of 1988 (NAVD 88; fig. 6). Numerous tree stumps are present along the bottom of the pond. The volume of water stored in Oglethorpe Lake and its surface area varies as pond stage changes. Pond stage was monitored from November 7 through December 31, 2008 (fig. 7). During this period, stage above NAVD 88 ranged from a high of $23.17 \mathrm{ft}$ on November 15, 2008, to a low of $21.37 \mathrm{ft}$ on December 31, 2008. Stage declined during this period largely as the result of leakage from the dam and discharge through an open gate valve.

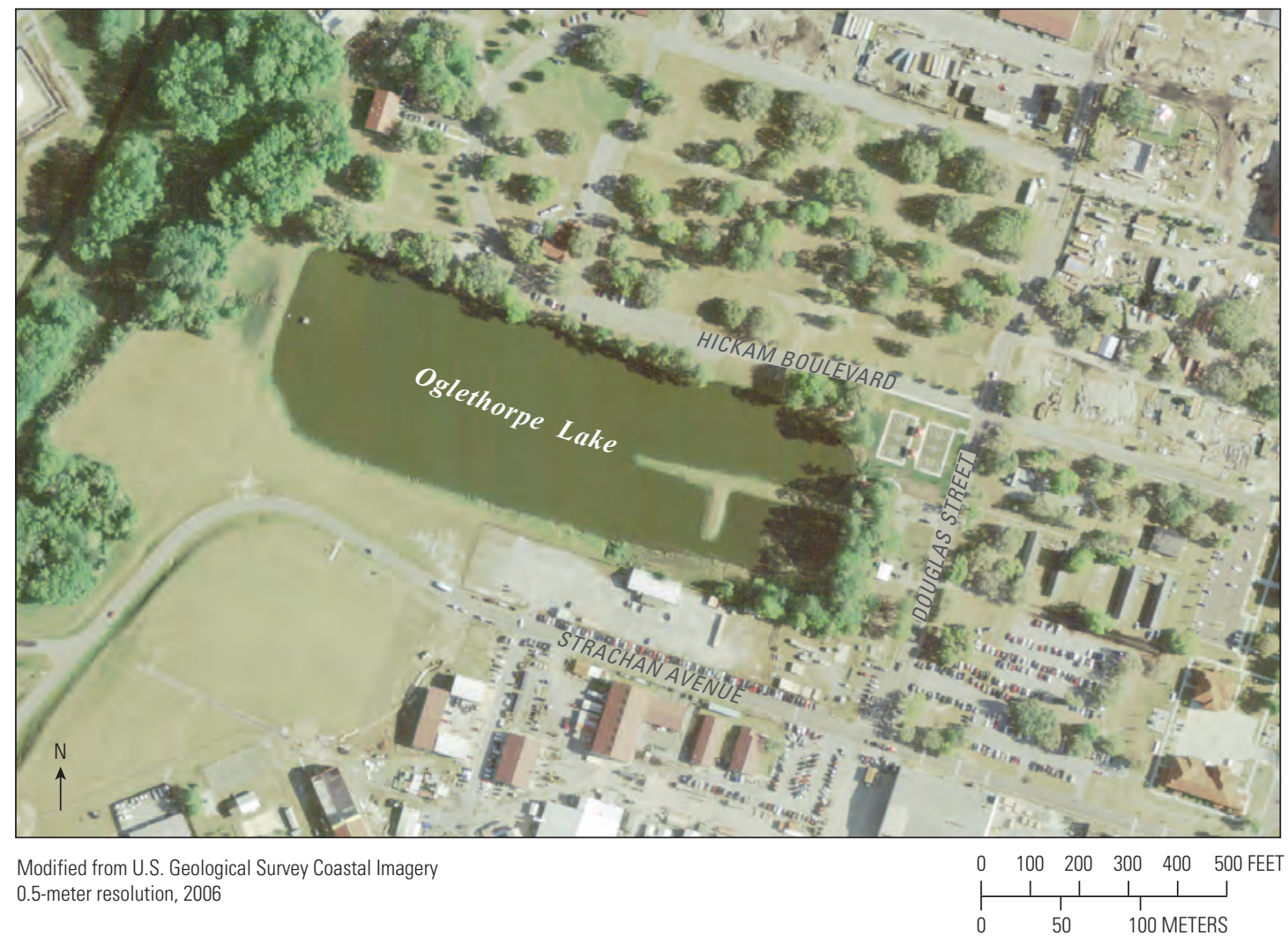

Figure 5. Oglethorpe Lake, Hunter Army Airfield, Chatham County, Georgia. 


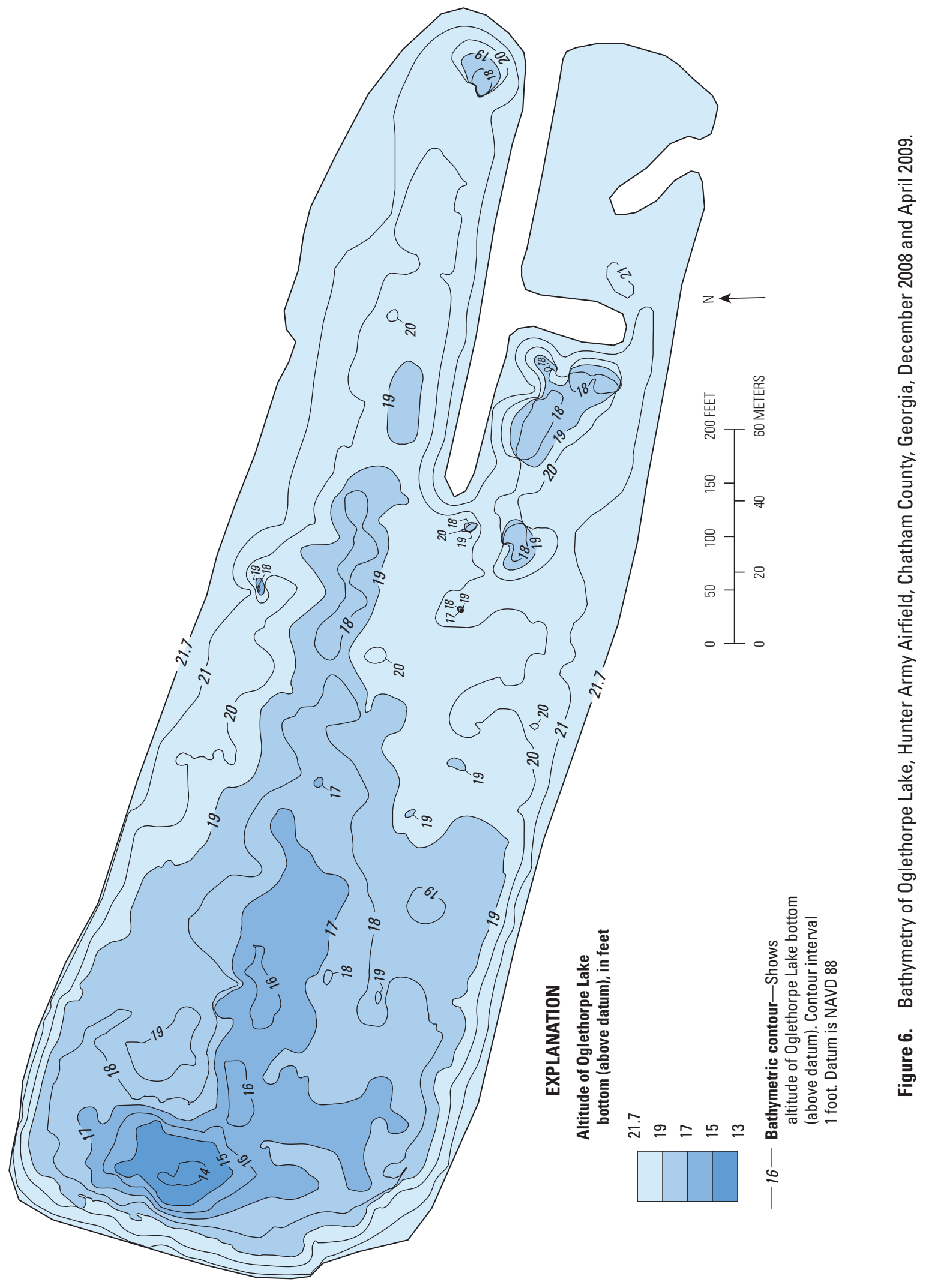



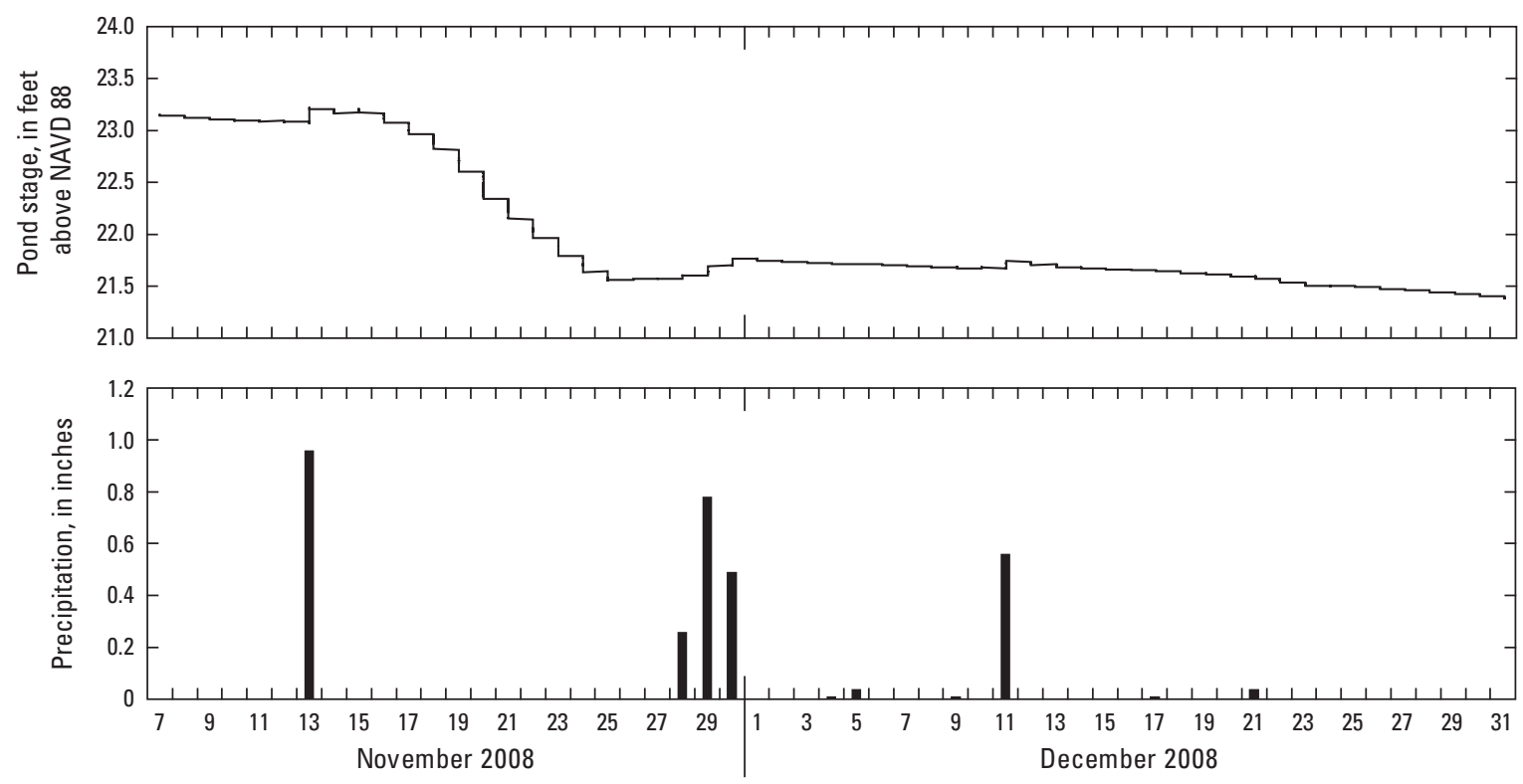

Figure 7. Stage and total daily precipitation at Oglethorpe Lake, Hunter Army Airfield, Chatham County, Georgia, November-December 2008. Stage recorded at 15-minute intervals.

Pond volume and surface area were estimated using thirdand second-order polynomial regression models, respectively, over a range of pond stages (fig. 8). At the highest recorded stage of $23.17 \mathrm{ft}$ above NAVD 88 on November 15, the volume of water stored in the pond was about 7.28 million gallons (Mgal), covering a surface area of 415,379 square feet $\left(\mathrm{ft}^{2}\right)$ or 9.53 acres. At the lowest recorded stage of $21.37 \mathrm{ft}$ above NAVD 88 on December 31, the volume of water in the pond was about $6.26 \mathrm{Mgal}$, covering a surface area of $372,588 \mathrm{ft}^{2}$ (8.55 acres)

\section{Water Budget}

A simplified water budget was developed for Oglethorpe Lake based on daily pond stage, precipitation, evaporation, and discharge data collected during November 7-December 31, 2008 (fig. 9). During this period, precipitation was limited to storms during November 13 and 28-30 and December 5, 11, and 21. Daily evaporation at the GaEMN Bamboo Farm site, ranged from 0.01 to 0.08 inch during November 7December 31, 2008.

The water budget for the pond can be expressed in terms of gains and losses to pond volume (fig. 9). Pond discharge is reflected as a loss to pond volume and is indicated by a negative value. Pnet is the difference between precipitation and evaporation, which provides an indication of the net gain $(+)$ or loss (-) of water to the pond when computed with Gnet and pond discharge. Pnet and Gnet can be either positive (reflecting gains to pond volume) or negative (reflecting a loss to pond volume). During the study period, values of Pnet were largely
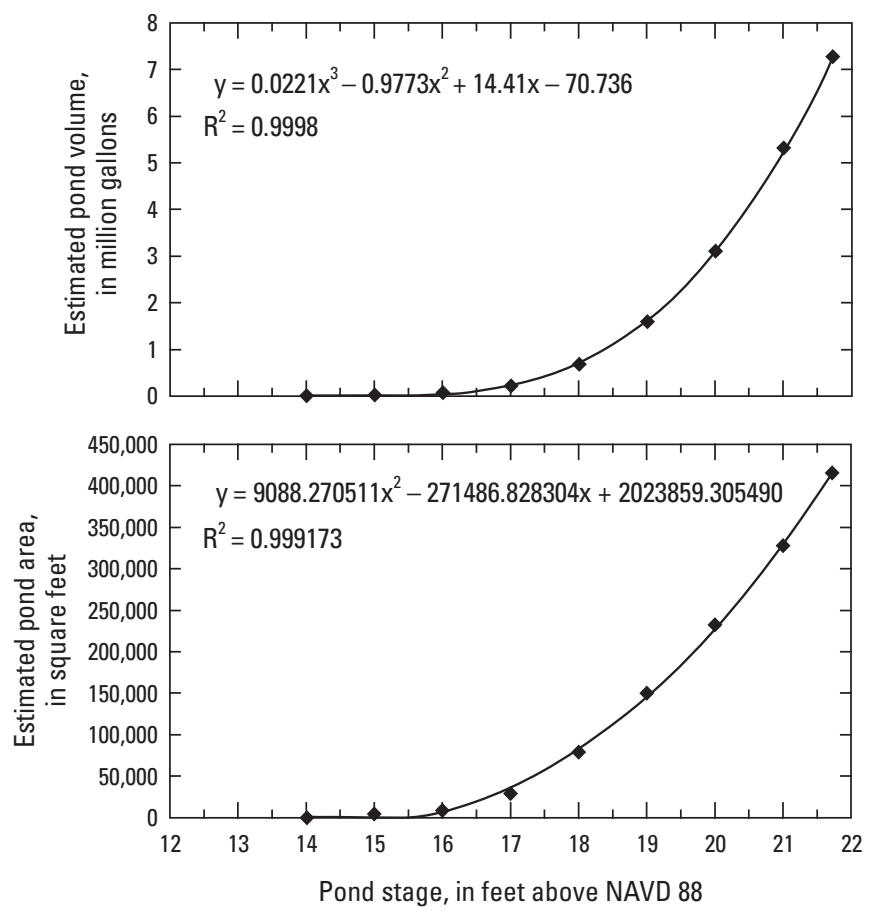

Figure 8. Relation of pond stage to computed volume and surface area, and regression fit of data, Oglethorpe Lake, Hunter Army Airfield, Chatham County, Georgia. 
negative, indicating more water was leaving the pond from evaporation than entering it from precipitation. Exceptions occur when Pnet values were positive during rainfall events.

To induce a change in pond stage and assess Gnet, water was discharged from the pond by opening a gate valve at a culvert along the earthen dam. The valve remained open during November 11-24, 2008, and produced an estimated discharge of $366 \mathrm{gal} / \mathrm{min}$. In addition to this induced discharge, the pond loses water by leakage through the dam. During visits to the site in November 2008, personnnel observed the pond leaking through the earthen dam at a rate of about $280 \mathrm{gal} / \mathrm{min}$ to a drainage outlet about $30 \mathrm{ft}$ below the top of the dam (fig. 10). Water was discharging from the lake through small submerged sinkholes located along the pondward side of the earthen dam (fig. 11). The sinkholes were formed as fill material was eroded away by moving water. When additional pond discharge was induced through the culvert, the leakage rate decreased to about $48 \mathrm{gal} / \mathrm{min}$ as pond stage was lowered beneath the position of some of the sinkholes. As pond stage rises to the position of the sinkholes, leakage from the pond is expected to increase. Total discharge from Oglethorpe Lake is the sum of culvert discharge and pond leakage (fig. 12). Leakage through the dam at Oglethorpe Lake resulted in less reliable estimates of pond discharge, with actual values likely higher than estimated. For this reason, an error of 25 percent was assigned to discharge values at Oglethorpe Lake.
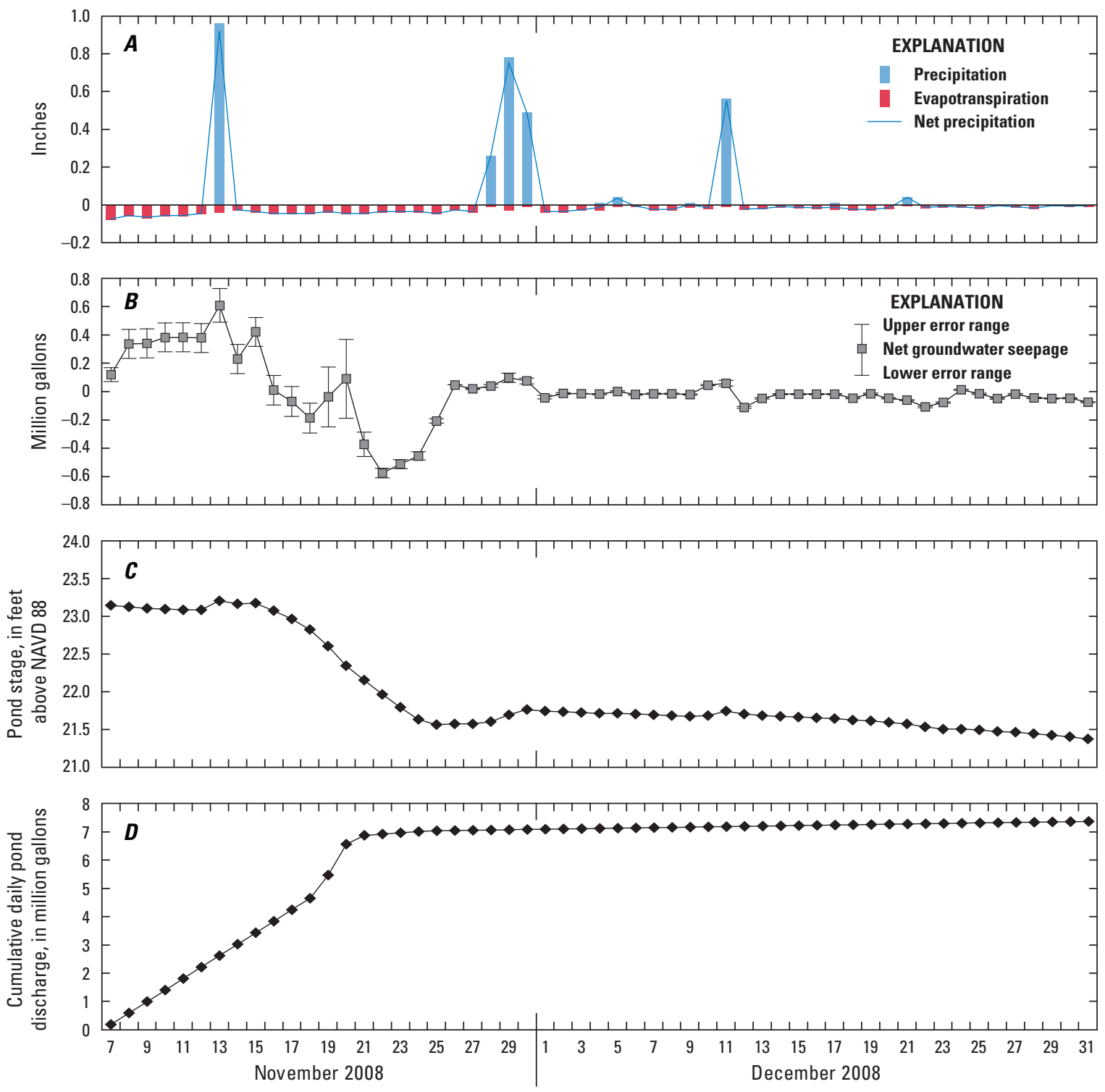

Figure 9. Hydrologic and climatic data at Oglethorpe Lake, Hunter Army Airfield, Chatham County, Georgia, and vicinity, November-December 2008. (A) Daily precipitation and net precipitation at Oglethorpe Lake, and estimated daily evapotranspiration at the Bamboo Farm, Georgia Environmental Monitoring Site; $(B)$ net groundwater seepage; $(C)$ pond stage; and $(D)$ cumulative daily pond discharge. 


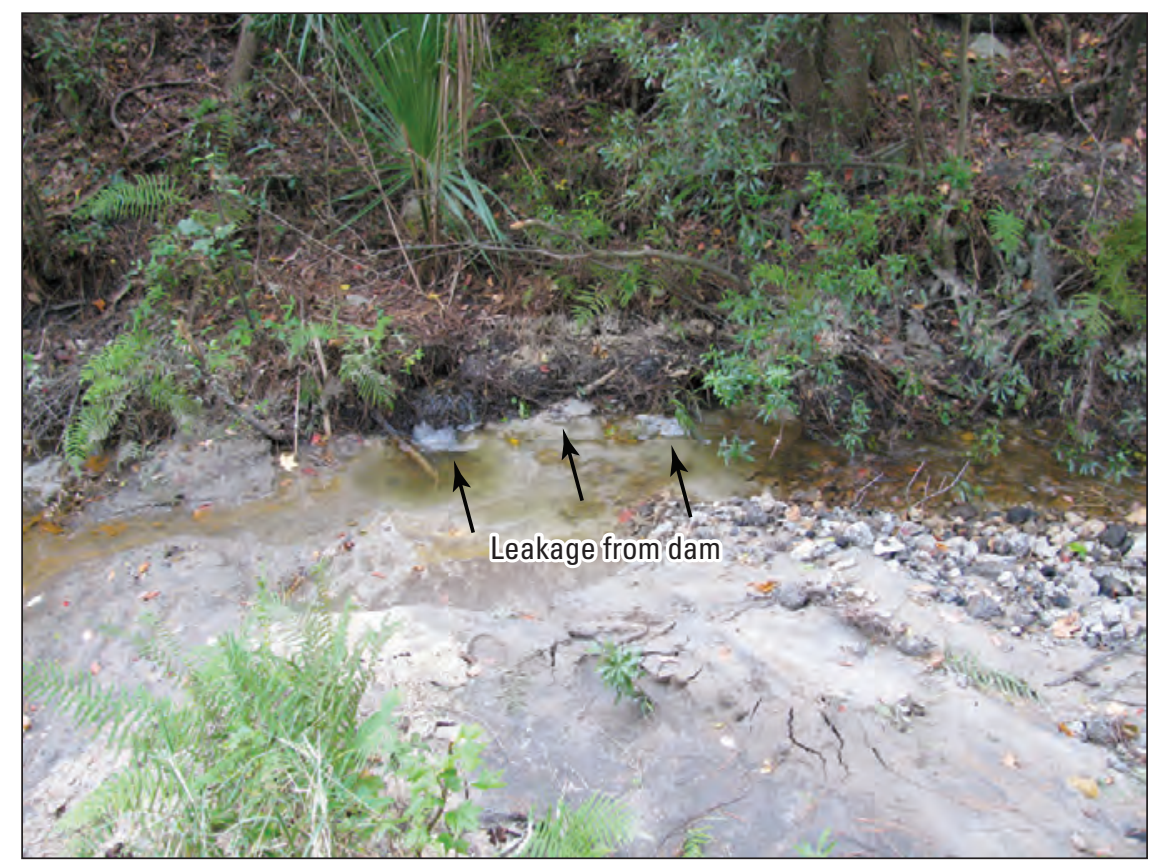

Figure 10. Dam leakage at Oglethorpe Lake, Hunter Army Airfield, Chatham County, Georgia, November 2008. Water is discharging into ditch about 30 feet beneath top of earthen dam at a rate of about 280 gallons per minute. Photograph by John S. Clarke, U.S. Geological Survey.

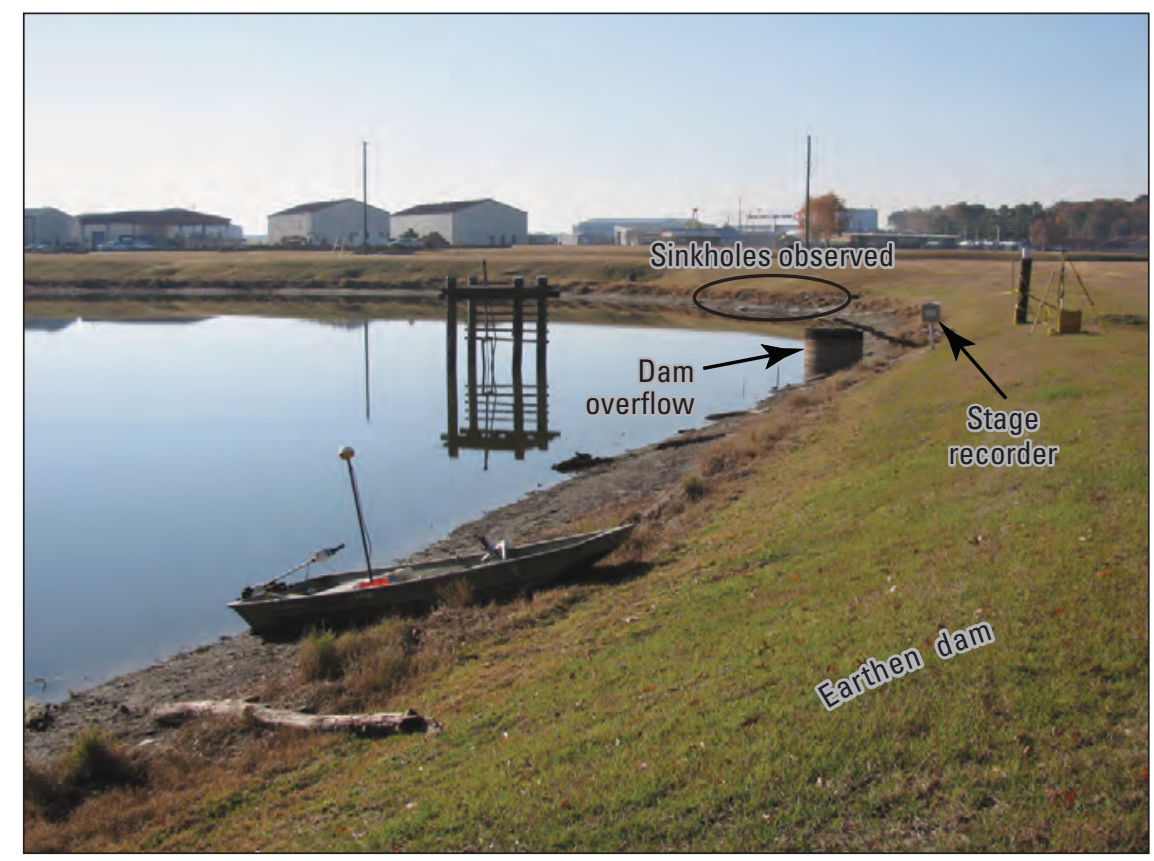

Figure 11. Oglethorpe Lake on December 3, 2008, after stage lowered by 1.42 feet. Circled area is where sinkholes were observed, with water discharging from the pond in several areas. In the foreground is the boat used for bathymetry survey. Photograph by John S. Clarke, U.S. Geological Survey. 
During November-December 2008, estimated daily Gnet ranged from +0.61 to $-0.57 \mathrm{Mgal}$ (fig. $9 B$ ). The largest computed daily Gnet gain (indicated by a positive value) occurred following a rainstorm on November 13, and the largest daily loss (indicated by a negative value) occurred November 22, following an 8-day period of no rainfall. Some of the large Gnet gain on November 13 could be attributed to stormwater inflow to the pond.

Discharge from the pond is affected by changes in pond volume, Gnet, and Pnet. Figure 13 shows cumulative values for change in pond volume, pond discharge, Pnet, and Gnet during November 7-December 31, 2008. During this period, pond stage was lowered by $1.8 \mathrm{ft}$, resulting in a loss in pond volume of about 6.7 Mgal. Estimated cumulative discharge from the pond during the same period totaled about 7.4 Mgal. Because the rate of discharge is faster than the change in pond volume, the area between the two lines on figure 13 represents additional discharge provided by Gnet and Pnet. Gnet during this period totaled about $0.24 \mathrm{Mgal}$, or 36 percent of the additional discharge volume, and Pnet was about $0.43 \mathrm{Mgal}$, or 64 percent of the discharge volume. The $0.24 \mathrm{Mgal}$ volume contributed by Gnet during the 55-day study period averages to a rate of only about $3 \mathrm{gal} / \mathrm{min}$. Higher Gnet inflows occurred following rainfall events, with the maximum daily value of $0.61 \mathrm{Mgal}$ on November 13, which is equivalent to a rate of $424 \mathrm{gal} / \mathrm{min}$ (fig. $9 \mathrm{~B}$ ). It is possible that some of the large Gnet gains following rainfall events can be attributed to stormwater inflow to the pond. The two longest periods of Gnet gains were on November 7-16 and 26-30 (fig. 9B):

- During November 7-16, dam leakage of about 3.84 Mgal resulted in a decline in pond stage of $0.07 \mathrm{ft}$ and a loss in pond volume of $0.46 \mathrm{Mgal}$ (figs. 9, 13). One storm event on November 13 resulted in a daily Pnet gain of about 0.17 Mgal. Gnet during November 7-16 contributed $3.21 \mathrm{Mgal}$ at an average rate of $223 \mathrm{gal} / \mathrm{min}$.

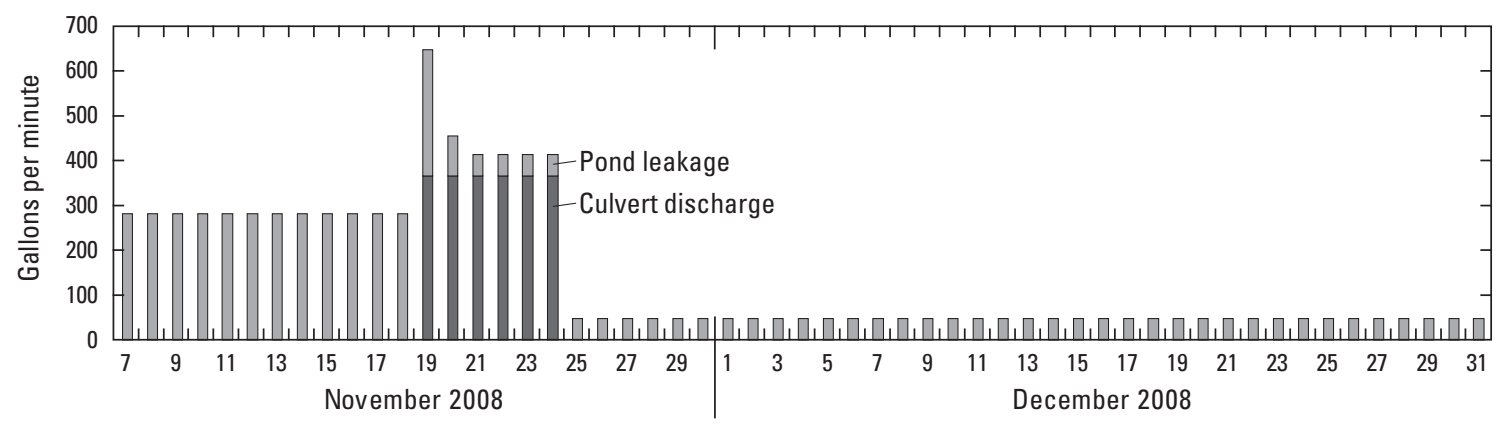

Figure 12. Daily average pond discharge at Oglethorpe Lake, Hunter Army Airfield, Chatham County, Georgia, November 7-December 31, 2008.

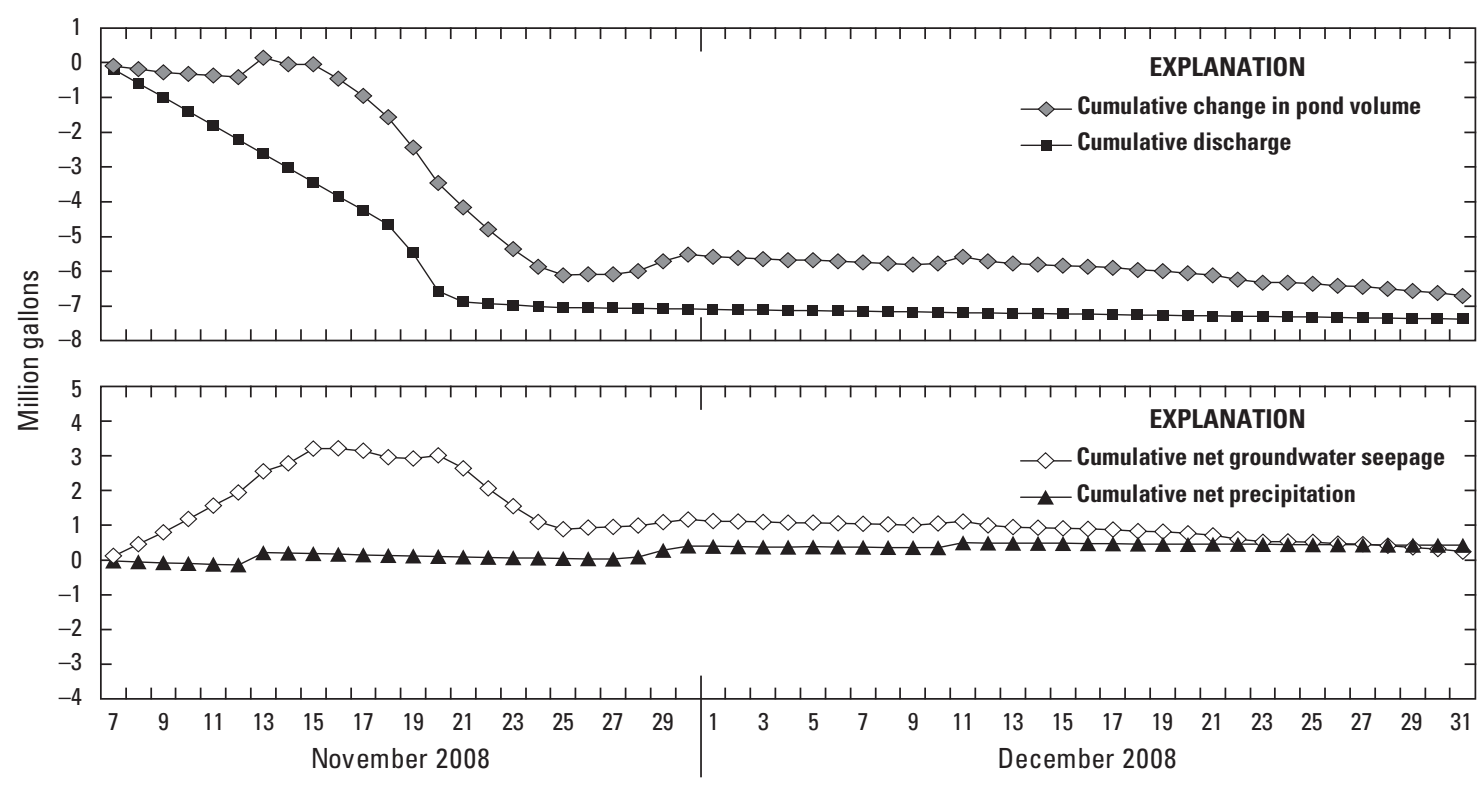

Figure 13. (A) Cumulative daily change in pond volume and discharge and $(B)$ net precipitation and net groundwater seepage, Oglethorpe Lake, Hunter Army Airfield, Chatham County, Georgia, NovemberDecember 2008. 
- During November 26-30, pond stage rose by $0.19 \mathrm{ft}$, resulting in a gain in pond volume of about $0.6 \mathrm{Mgal}$ (figs. 9, 13). This gain in volume occurred despite dam leakage volume loss of about $0.05 \mathrm{Mgal}$, and was largely the result of precipitation on November 28-30 that resulted in a Pnet gain of $0.36 \mathrm{Mgal}$ during this period. Gnet contributed $0.28 \mathrm{Mgal}$ over the 3-day period at an average rate of $39 \mathrm{gal} / \mathrm{min}$.

Uncertainty in Gnet estmates are due to combined errors associated with precipitation, evaporation, volume, and discharge computed using equation 2 . The largest error for daily Gnet estimates (0.28 Mgal) occurred November 20, when pond discharge was highest (fig. 9B). Because a 25 -percent error was assigned to discharge at Oglethorpe Lake, the high discharge on these dates resulted in a larger overall error range. The variation in Gnet error was smaller during periods of decreased discharge from the pond.

\section{Water Quality}

To assess water quality at Oglethorpe Lake, field properties (specific conductance, dissolved oxygen, water temperature, and $\mathrm{pH}$ ) were measured at four discrete depths in the deepest area of the pond near the dam on April 22, 2009 (fig. 14). The deepest part of the pond is about $9 \mathrm{ft}$ deep; measurements were collected at $8,6,4$, and $2 \mathrm{ft}$. Temperature, $\mathrm{pH}$, and dissolved oxygen gradually decrease with depth. Conversely, specific conductance slightly increases with depth. Levels of $\mathrm{pH}$ ranged from 6.3 to 7.2 and were within the Georgia Environmental Protection Division (GaEPD) standard for waters supporting warm-water species of fish of 6.0-8.5 (Georgia Department of Natural Resources, 2005). Levels of dissolved oxygen met the GaEPD standard of 4 milligrams per liter $(\mathrm{mg} / \mathrm{L})$ for water supporting warm-water species of fishes (Georgia Department of Natural Resources, 2005), with the exception of the deepest water, measured at $8 \mathrm{ft}$, which had a dissolved oxygen concentration of only $3.3 \mathrm{mg} / \mathrm{L}$.

A composite water sample was collected on April 22, 2009 , from the four depth intervals, and analyzed for the dissolved constituents listed in table 1. Analytical results indicate that water from Oglethorpe Lake is low in dissolved solids and concentrations of most constituents. The water is fresh, with chloride concentration of $3.85 \mathrm{mg} / \mathrm{L}$. Concentrations of analyzed constituents are all within U.S. Environmental Protection Agency primary and secondary maximum contaminant levels (MCLs) for drinking water (U.S. Environmental Protection Agency, 2009).

Table 1. Water quality analysis of ponds at Hunter Army Airfield, Chatham County, Georgia, April 2009.

$[<$, less than; E, estimated value; - , no data $]$

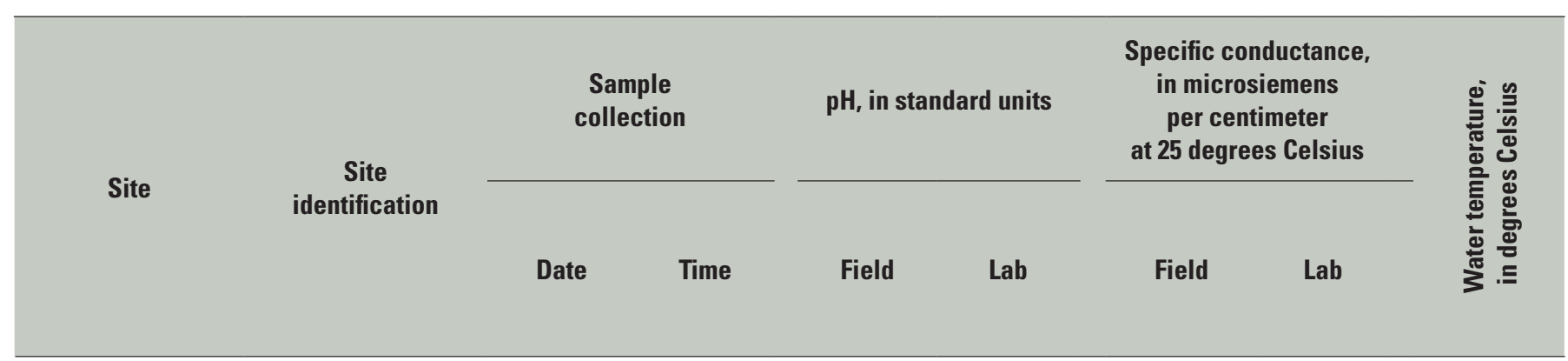

U.S. Environmental Protection Agency Secondary Maximum Contaminant Level (U.S. Environmental Protection Agency, 2009):

\begin{tabular}{llllllrrr} 
Halstrum Pond & 320006081093901 & $4 / 21 / 2009$ & 1030 & 5.4 & 6.2 & 58 & E60 & 18.5 \\
Golf course pond & 320021081074501 & $4 / 22 / 2009$ & 1300 & 6 & 6.8 & 105 & 108 & 21.3 \\
Wilson Gate Pond & 320051081070601 & $4 / 21 / 2009$ & 1330 & 5.3 & 7 & 86 & E88 \\
Oglethorpe Lake & 320143081082701 & $4 / 22 / 2009$ & 1030 & 6.9 & 6.7 & 150 & 154 & 20.2 \\
\hline
\end{tabular}



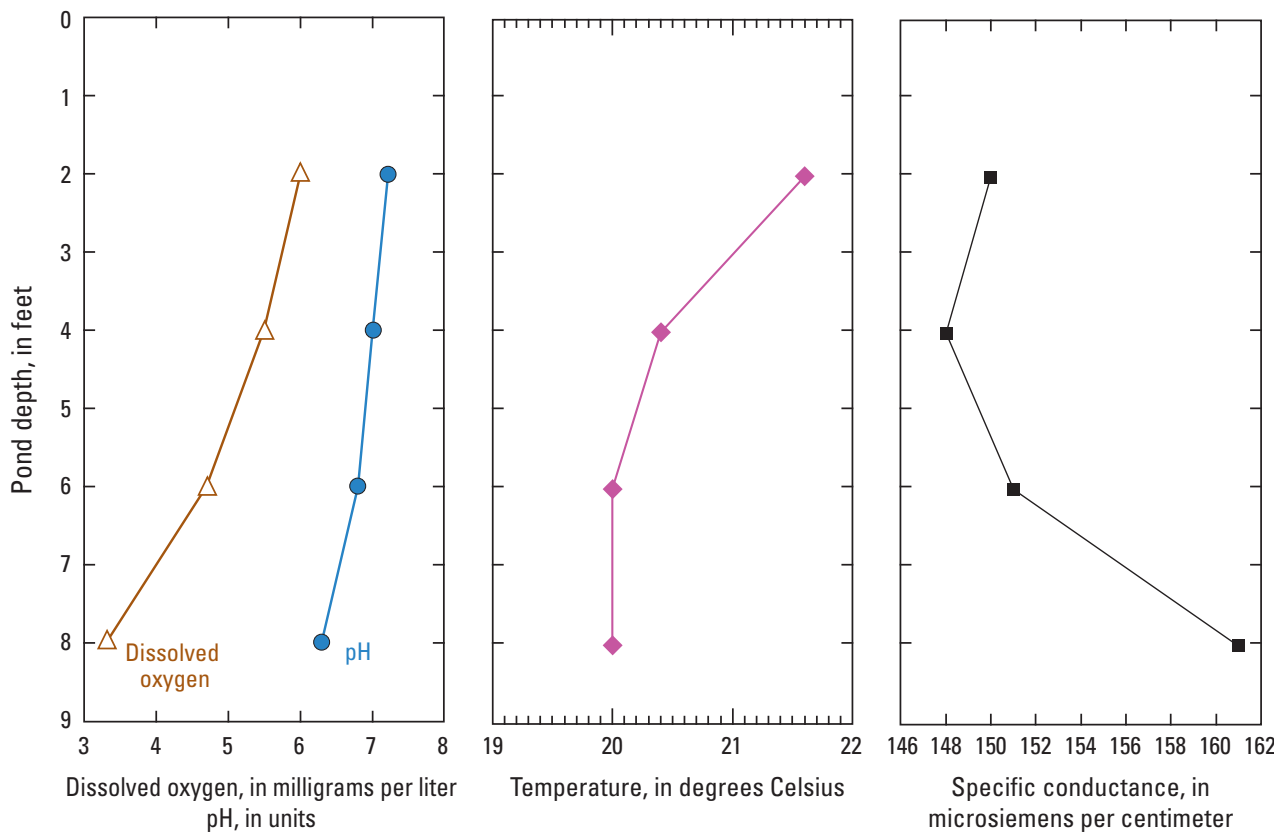

Figure 14. Water-quality profile at Oglethorpe Lake, Hunter Army Airfield, Chatham County, Georgia, April 22, 2009.

Table 1. Water quality analysis of ponds at Hunter Army Airfield, Chatham County, Georgia, April 2009.—Continued $[<$, less than; E, estimated value; - , no data $]$

\begin{tabular}{|c|c|c|c|c|c|c|c|c|c|c|c|c|c|c|c|c|}
\hline \multicolumn{15}{|c|}{ Milligrams per liter } & \multicolumn{2}{|c|}{$\begin{array}{c}\text { Micrograms } \\
\text { per liter }\end{array}$} \\
\hline 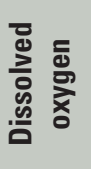 & 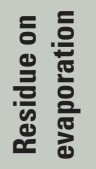 & 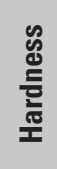 & 豆 & 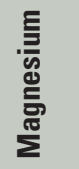 & 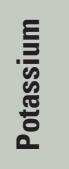 & $\begin{array}{l}\text { E } \\
\text { 吾 } \\
\text { 品 }\end{array}$ & 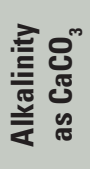 & $\frac{\text { 은 }}{\frac{0}{}}$ & $\begin{array}{l}\text { 은 } \\
\text { 은 }\end{array}$ & 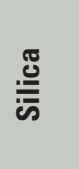 & 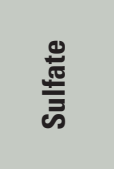 & 焉 & 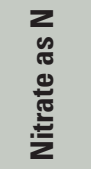 & 흘 & 흔 & 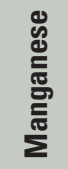 \\
\hline 14 & - & - & - & - & - & - & - & 250 & 24 & - & 250 & - & 10 & - & 300 & 50 \\
\hline 1.3 & 38 & 15 & 3.75 & 1.39 & 0.9 & 4.09 & 9 & 6.52 & $<.08$ & 0.5 & 5.81 & .082 & $<.04$ & E.008 & 224 & 22.7 \\
\hline 3.8 & 82 & 36 & 11.7 & 1.55 & 1 & 5.2 & 26 & 7.09 & E.05 & 7.6 & 12.4 & $<.020$ & $<.04$ & .030 & 211 & 35.3 \\
\hline
\end{tabular}

${ }^{1}$ Georgia Environmental Protection Division standard for waters supporting warm-water species of fish (Georgia Department of Natural Resources, 2005) ${ }^{2}$ Primary Standard 


\section{Halstrum Pond}

Halstrum Pond, also known as pond 24, is a 4.6-acre pond constructed in 1968 (fig. 15). The pond has a maximum depth of about $17 \mathrm{ft}$ and is contained by an earthen dam (fig. 16). The pond is used to capture stormwater and is also used as a fishing pond. The pond captures runoff from Perimeter Road to the south and from a drainage ditch located east of the pond. Field studies at Halstrum Pond were conducted during November 10-December 31, 2008.

\section{Bathymetry and Pond Volume}

A bathymetric survey conducted on December 4, 2008, indicates the altitude of the bottom of Halstrum Pond ranges from about 11 to $26 \mathrm{ft}$ above NAVD 88 (fig. 17). The volume of water stored in Halstrum Pond and its surface area vary as pond stage changes. Pond stage was monitored from November 10 through December 31, 2008 (fig. 18). During this period, stage above NAVD 88 ranged from a high of $27 \mathrm{ft}$ on November 13, 2008, to a low of $25.7 \mathrm{ft}$ on November 20, 2008. Stage declined during this period largely as the result of discharge through an open gate valve during November 18-20 and rose in response to rainfall events on November 13, 15, 28-30, and December 11.

Pond volume and area were estimated using a GIS and second-order polynomial regression models to provide values for a range of pond stages (fig. 19). At the highest recorded stage of $27 \mathrm{ft}$ above NAVD 88 on November 13, the volume of water stored in the pond was about $12.8 \mathrm{Mgal}$, covering a surface area of 200,408 $\mathrm{ft}^{2}$, or 4.6 acres. At the lowest recorded stage of $25.7 \mathrm{ft}$ above NAVD 88 on November 20, the volume of water in the pond was about $10.8 \mathrm{Mgal}$, covering a surface area of $187,348 \mathrm{ft}^{2}$, or 4.3 acres.

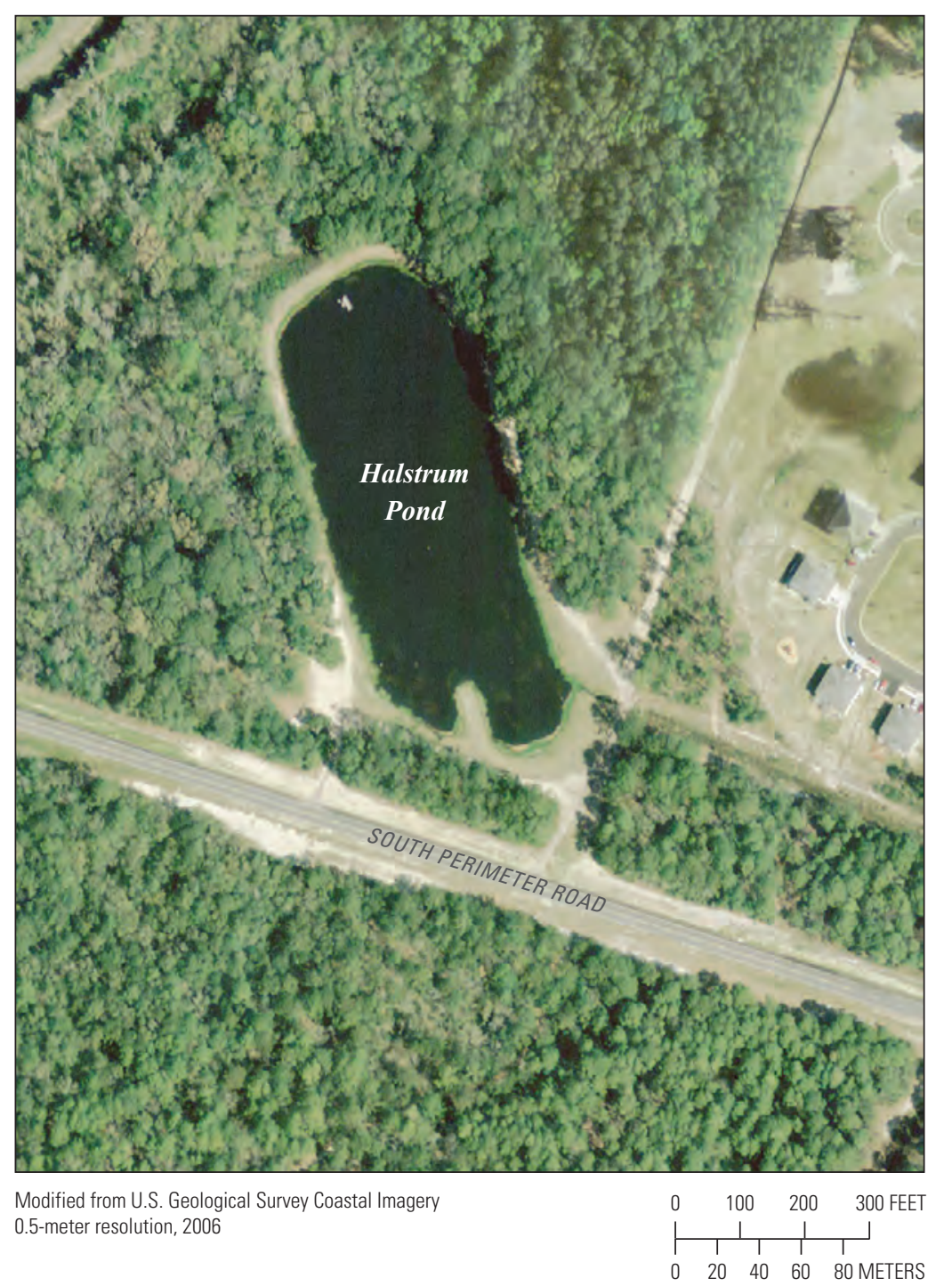

Figure 15. Halstrum Pond, Hunter Army Airfield, Chatham County, Georgia. 
Figure 16. Halstrum Pond looking westward toward earthen dam, Hunter Army Airfield, Chatham County, Georgia.
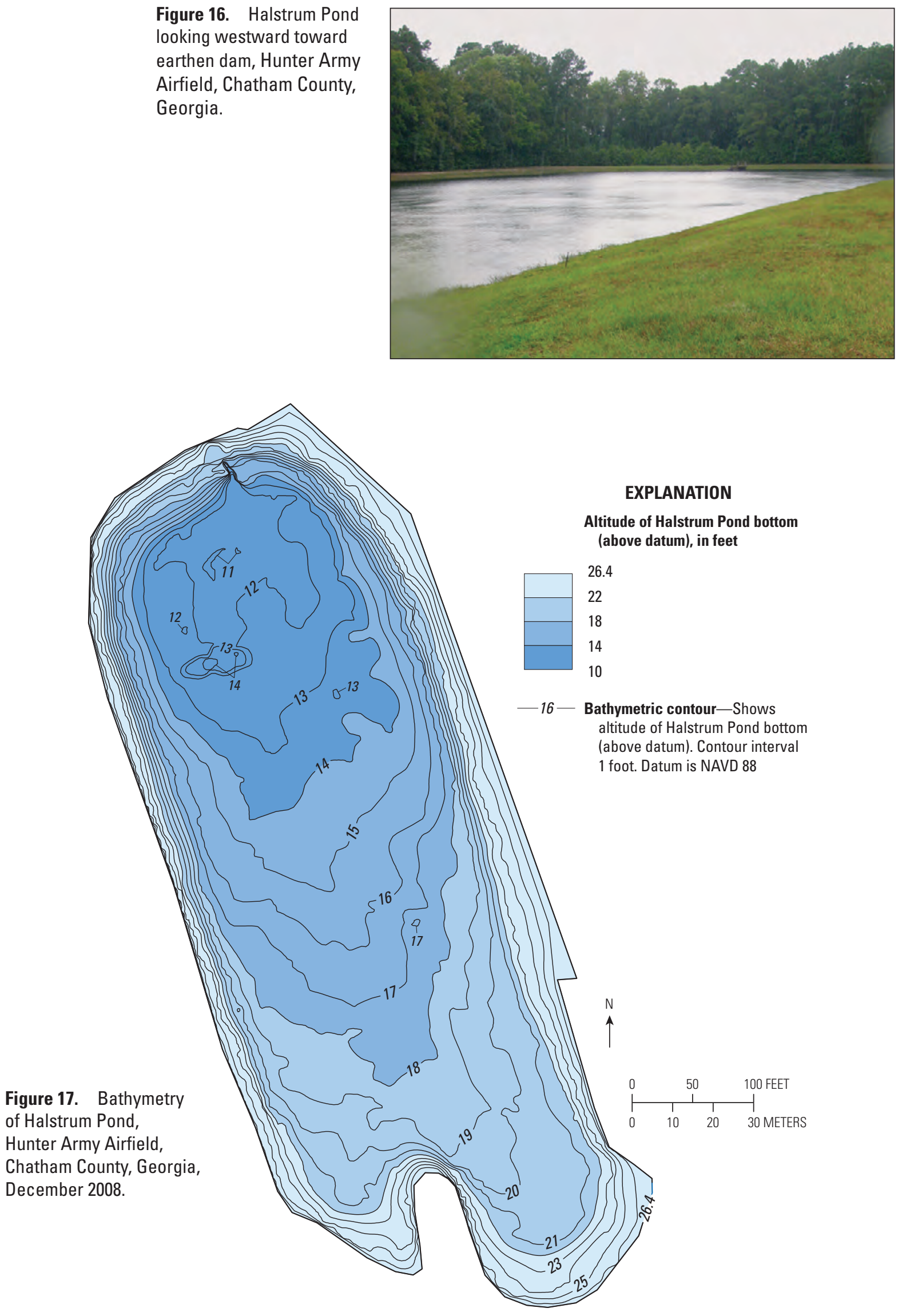

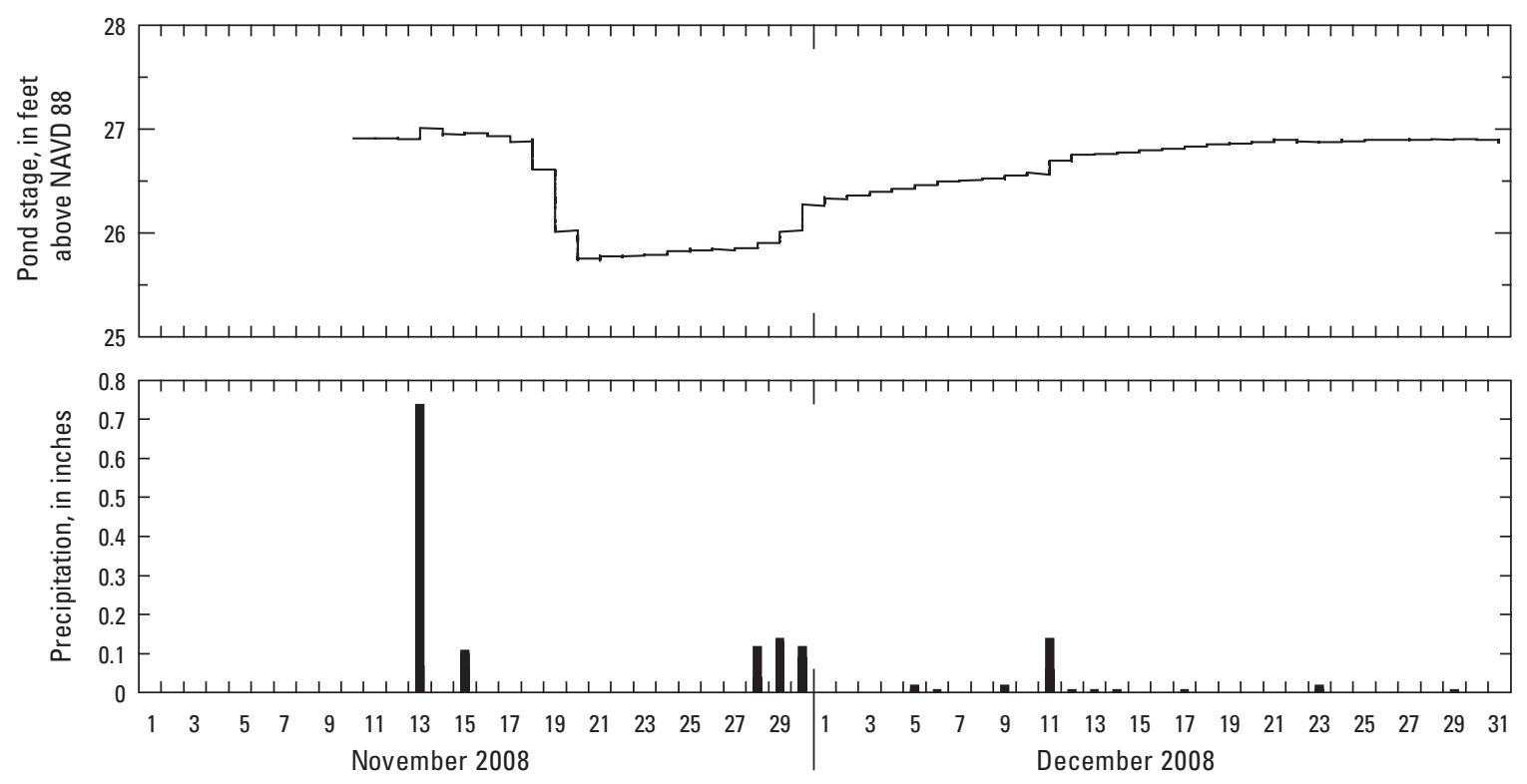

Figure 18. Stage and daily total precipitation at Halstrum Pond, Hunter Army Airfield, Chatham County, Georgia, November-December 2008. Stage recorded at 15-minute intervals.
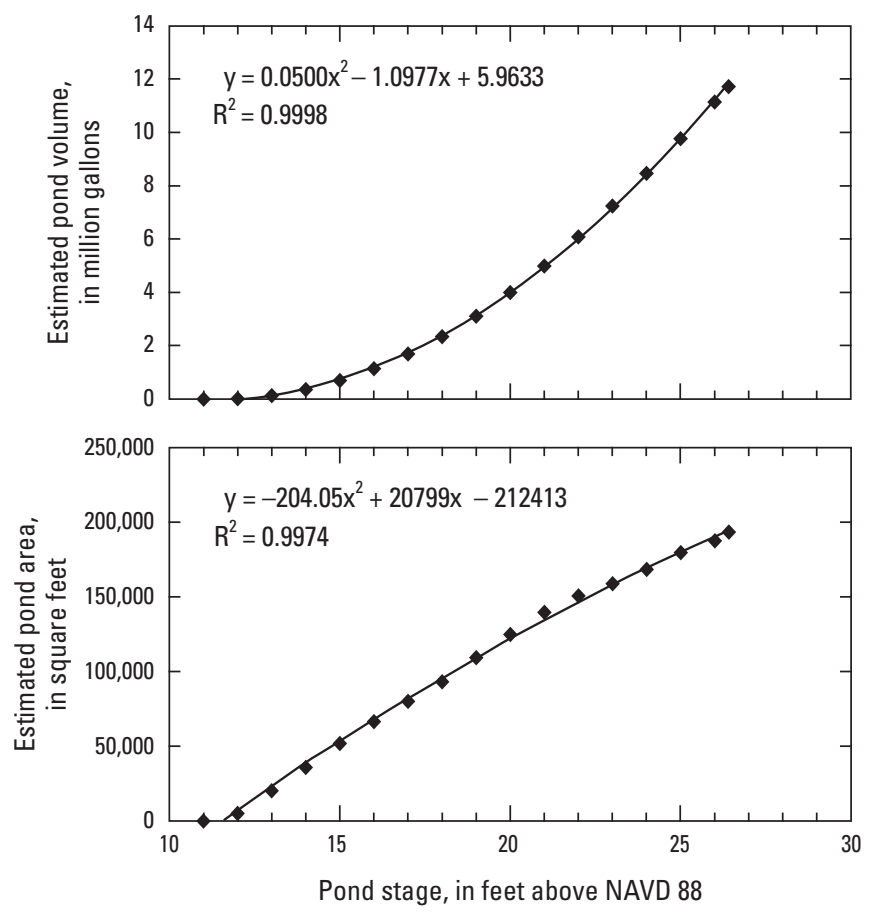

Figure 19. Relation of pond stage to computed volume and surface area, and regression fit of data, Halstrum Pond, Hunter Army Airfield, Chatham County, Georgia.

\section{Water Budget}

A simplified water budget was developed for Halstrum Pond based on daily pond stage, precipitation, evaporation, net precipitation, and discharge data collected during November 10-December 31, 2008 (fig. 20). During this period, precipitation was limited to storms during November 13, 15, and 28-30 and December 5, 9, 11-12, 21, and 23. Daily evapotranspiration at the GaEMN site, Bamboo Farm, ranged from 0.01 to 0.06 inch during November 10-December 31, 2008.

During the study period, values of Pnet were mostly negative, indicating that more water was leaving the pond from evaporation than entering it from precipitation (fig. 20A). Exceptions occurred when Pnet values were positive during rainfall events.

To produce a change in pond stage and assess Gnet, pond discharge was induced by opening a gate valve at a culvert along the earthen dam. The valve remained open during November 18-20 and produced an estimated discharge of 120-668 gal/min, for an average rate of $0.65 \mathrm{Mgal} / \mathrm{d}$ for the 3-day period.

During November-December 2008, estimated daily Gnet was mostly positive (reflecting gains in pond volume), ranging from -0.11 to $+0.25 \mathrm{Mgal}$ (fig. 20B). The largest daily Gnet gain (indicated by a positive value) occurred following a rainstorm on November 30, and the largest daily loss (indicated by a negative value) occurred on November 15 . The November 15th Gnet loss followed rainfall events on November 13 and 15, indicating a possible time lag for rainfall to affect Gnet. During the 52-day study period, Gnet 
contributed a total accumulated volume of $1.34 \mathrm{Mgal}$, which is equivalent to a rate of $19 \mathrm{gal} / \mathrm{min}$. Higher Gnet inflows occurred following rainfall events, with the maximum daily value of $0.25 \mathrm{Mgal}$ on November 30, equivalent to a rate of $175 \mathrm{gal} / \mathrm{min}$. Some of the large Gnet gains following rainfall events could be attributed to stormwater inflow to the pond.

Uncertainty in Gnet estimates are due to combined errors associated with precipitation, evaporation, volume, and discharge computed using equation 2 . The largest daily error for Gnet estimates (0.11 Mgal) occurred November 19, when pond discharge was highest. Because a 10-percent error was assigned to discharge at Halstrum Pond, the high discharge on these dates resulted in a larger overall error range. The variation in Gnet error was smaller during periods of decreased discharge from the pond.
Discharge from Halstrum pond is affected by changes in pond volume, Gnet, and Pnet. Figure 21 shows the cumulative values for change in pond volume, pond discharge, Pnet, and Gnet during November 10-December 31, 2008. During this period, pond stage decreased in response to pond discharge and Pnet and Gnet losses, and rose in response to gains in Pnet and Gnet (fig. 20).

A test was conducted during November 18-20 to determine the influence of changes in pond stage on Gnet (fig. 21). The test involved opening a gate valve to release water and lower pond stage, while monitoring discharge, pond stage, precipitation, and evaporation. The 3-day test released a total volume of $1.95 \mathrm{Mgal}$ of water, and lowered pond stage by $1.12 \mathrm{ft}$, resulting in a loss in pond volume of about $1.72 \mathrm{Mgal}$. Because the volume of pond discharge is $0.24 \mathrm{Mgal}$ higher than
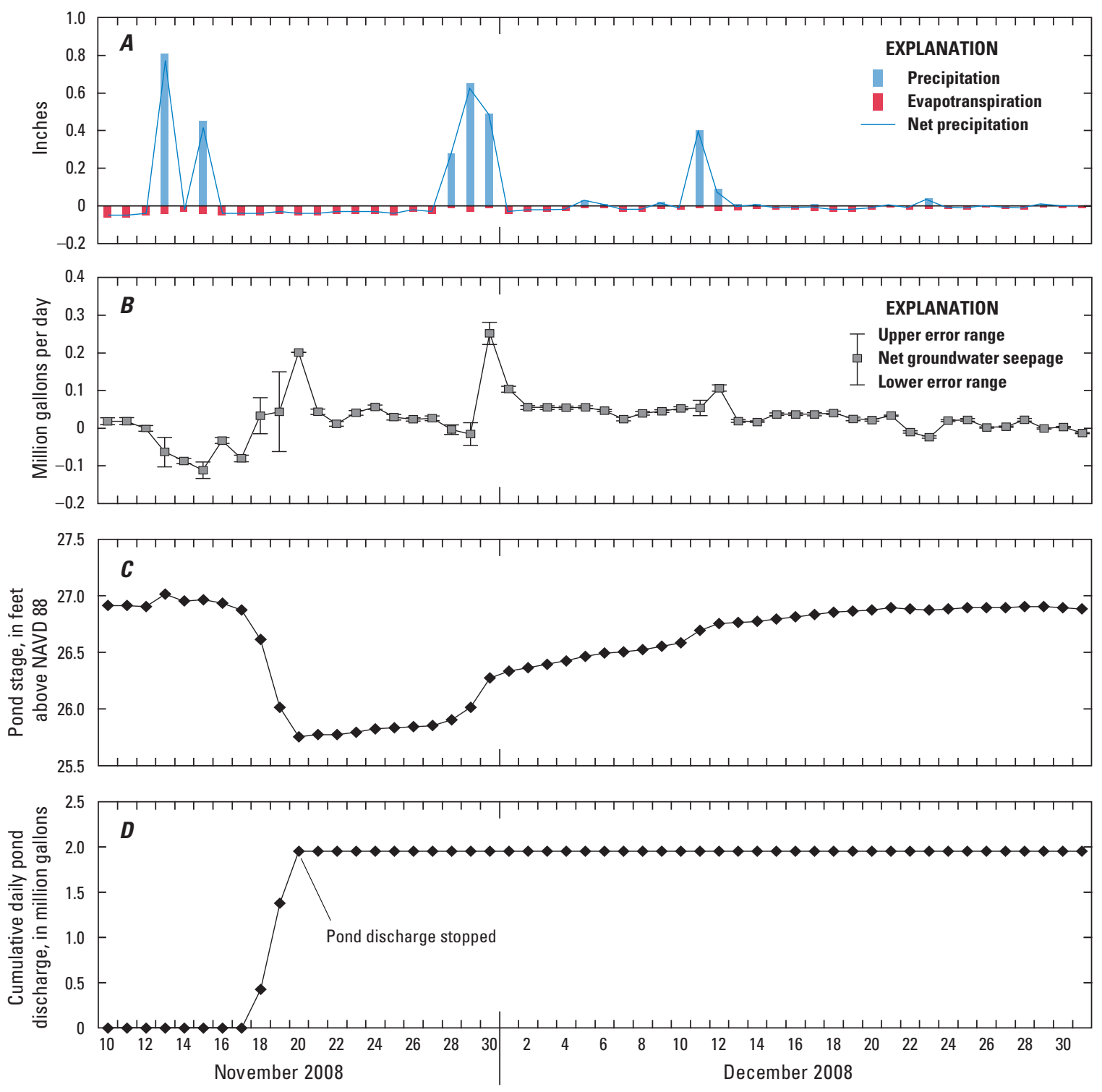

Figure 20. Hydrologic and climatic data at Halstrum Pond, Hunter Army Airfield, Chatham County, Georgia, and vicinity, November-December 2008. (A) Daily precipitation and net precipitation at the Halstrum Pond, and estimated daily evapotranspiration at the Bamboo Farm, Georgia Environmental Monitoring Site; $(B)$ net groundwater seepage; $(C)$ pond stage; and $(D)$ cumulative daily pond discharge. 


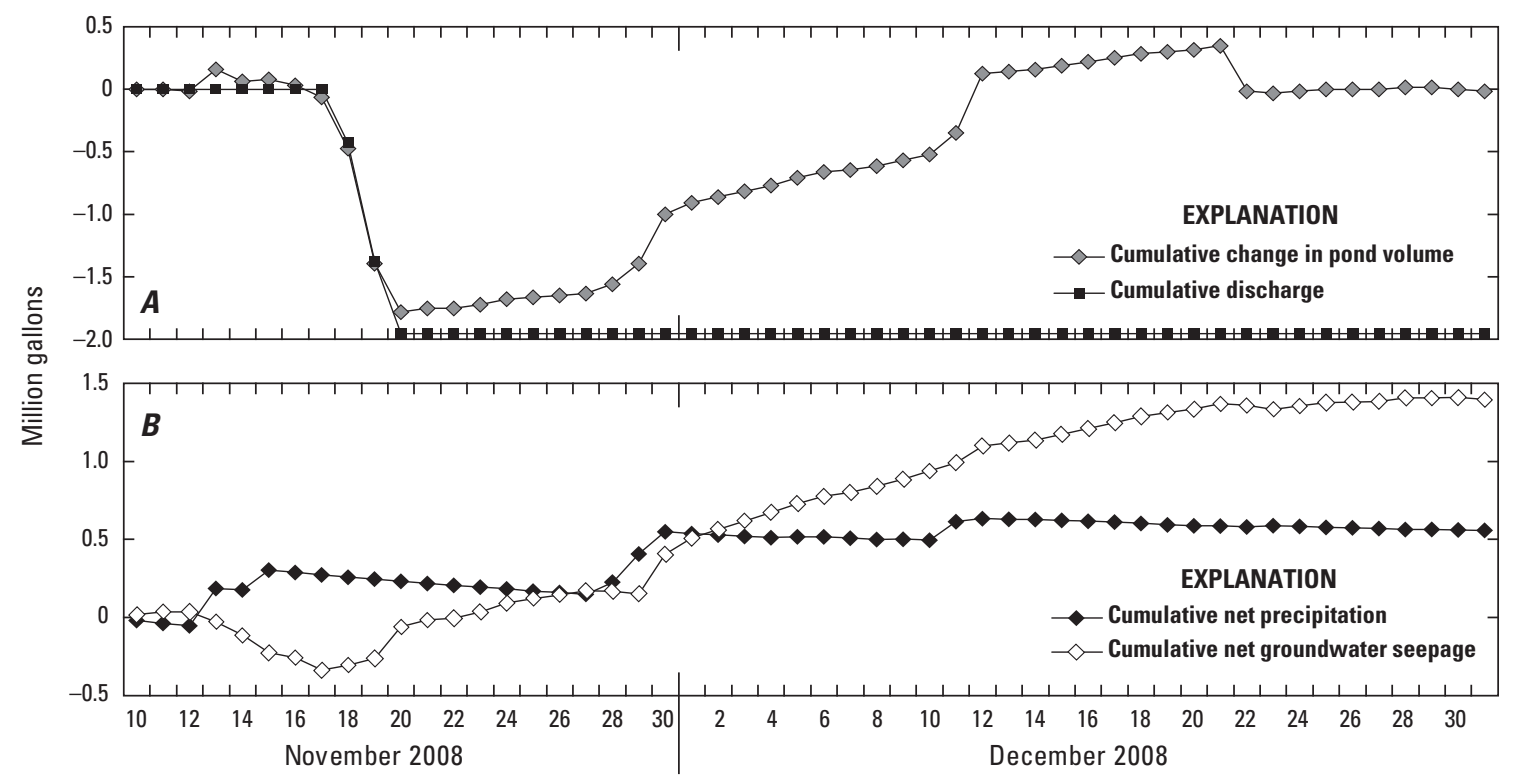

Figure 21. (A) Cumulative daily change in pond volume and discharge and $(B)$ net precipitation and net groundwater seepage, Halstrum Pond, Hunter Army Airfield, Chatham County, Georgia, November-December 2008.

the change in pond volume, the area between the two lines on figure $21 A$ represents additional water provided by Gnet and Pnet. The total Pnet volume during this period was $-0.04 \mathrm{Mgal}$, so that Gnet totaled about $0.28 \mathrm{Mgal}$ for a net gain in pond volume of $0.24 \mathrm{Mgal}$. Over the 3-day period, the average rate of Gnet into the pond was $65 \mathrm{gal} / \mathrm{min}$. The pond gate valve was shut off on November 20, and recovery was monitored for a 7-day period of no rainfall (fig. 20). During this period, pond stage rose by $0.1 \mathrm{ft}$, for an increase in volume of $0.15 \mathrm{Mgal}$. Pnet totalled -0.08 Mgal due to evaporative loss, and Gnet contributed $0.23 \mathrm{Mgal}$. Over the 7-day period, the average rate of Gnet into the pond was $0.03 \mathrm{Mgal} / \mathrm{d}$, or $23 \mathrm{gal} / \mathrm{min}$.

\section{Water Quality}

To assess water quality at Halstrum Pond, field properties (specific conductance, dissolved oxygen, water temperature, and $\mathrm{pH}$ ) were measured at eight discrete depths at the deepest part of the pond near the dam on April 22, 2009 (fig. 22). The deepest part of the pond is about $17 \mathrm{ft}$ deep; measurements were collected at 2-ft intervals from 2 to $16 \mathrm{ft}$. Values of $\mathrm{pH}$ and specific conductance vary little with depth, with $\mathrm{pH}$ values ranging from 5.3 to 5.6 units and specific conductance ranging from 55 to 89 microsiemens per centimeter $(\mu \mathrm{s} / \mathrm{cm})$. Levels of $\mathrm{pH}$ did not meet the GaEPD standard of 6.0-8.5 for waters supporting warm-water species of fish (Georgia Department of Natural Resources, 2005).

Water in the pond shows a decrease in temperature and dissolved oxygen with depth. Temperature was 22.1 degrees Celsius $\left({ }^{\circ} \mathrm{C}\right)$ at a depth of $2 \mathrm{ft}$ and was $14.8^{\circ} \mathrm{C}$ at a depth of $16 \mathrm{ft}$. Dissolved oxygen decreases from a high of $6.2 \mathrm{mg} / \mathrm{L}$ at a depth of $2 \mathrm{ft}$ to less than $1 \mathrm{mg} / \mathrm{L}$ at depths of $10 \mathrm{ft}$ or greater. At depths of $8 \mathrm{ft}$ and greater, levels of dissolved oxygen did not meet the $4 \mathrm{mg} / \mathrm{L} \mathrm{GaEPD}$ standard for water supporting warm-water species of fishes (Georgia Department of Natural Resources, 2005).

A composite water sample was collected on April 21, 2009 , from the 2- and 12-ft depth intervals and was analyzed for the dissolved constituents shown in table 1. Analytical results indicate water from Halstrum Pond is low in dissolved solids and concentrations of most constituents. The water is fresh, with chloride concentration of $6.52 \mathrm{mg} / \mathrm{L}$. Constituent concentrations are all within U.S. Environmental Protection Agency primary and secondary drinking-water MCLs.
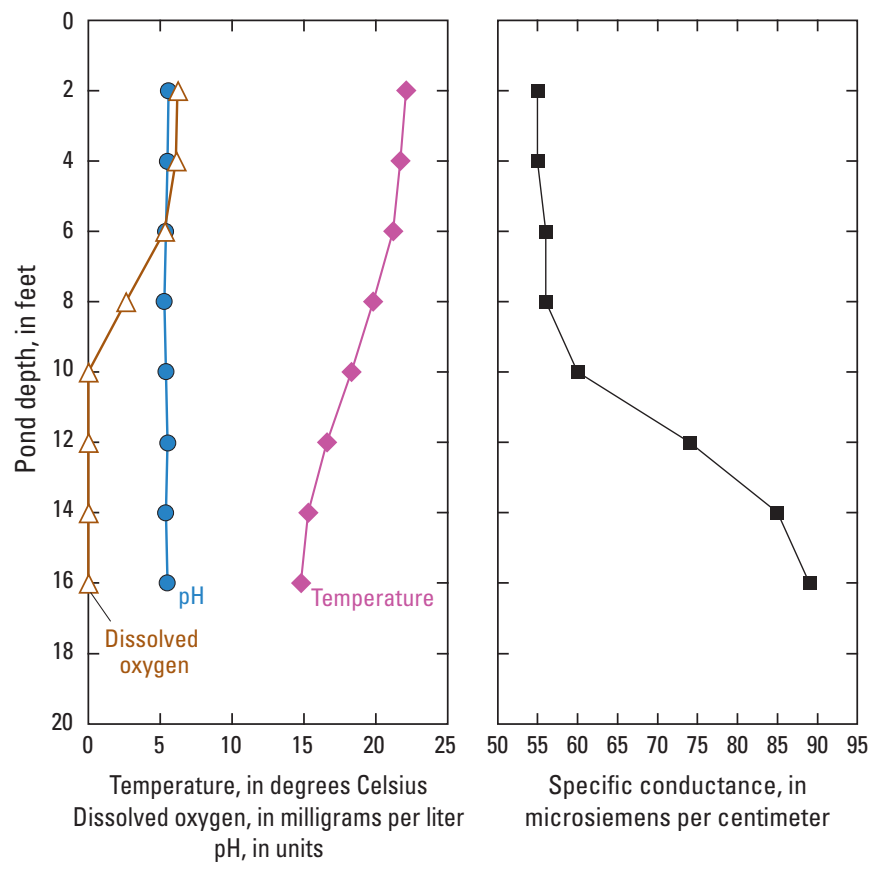

Figure 22. Water-quality profile at Halstrum Pond, Hunter Army Airfield, Chatham County, Georgia, April 21, 2009. 


\section{Wilson Gate Pond}

Wilson Gate Pond, also known as pond 35, is a 4.7-acre pond (fig. 23) constructed in 1998 with a maximum depth of about $7 \mathrm{ft}$. The pond serves to capture stormwater runoff from a drainage ditch located along White Bluff Road near the eastern perimeter of the installation and is also used for fishing (fig. 24). Stormwater enters the pond through a four-pipe culvert, and has an overflow discharge pipe that passes beneath North Perimeter Road. A stormwater monitor records precipitation and stream-water-quality properties during storm events.

\section{Bathymetry and Pond Volume}

A bathymetric survey conducted on December 2, 2008, indicates that the altitude of the bottom of Wilson Gate Pond ranges from about 8 to $13 \mathrm{ft}$ above NAVD 88 (fig. 25). The volume of water stored in Wilson Gate Pond and its surface area varies as pond stage changes. Pond stage was monitored from November 7 through December 31, 2008 (fig. 26). During this period, stage above NAVD 88 ranged from a high of $13.22 \mathrm{ft}$ on November 30,2008 , to a low of $12.88 \mathrm{ft}$ on November 27, 2008. Rising stage during this period was due to precipitation on November 13, November 28-30, and December 11, and stage declines were largely the result of evaporation and possible discharge from the pond through the culvert.

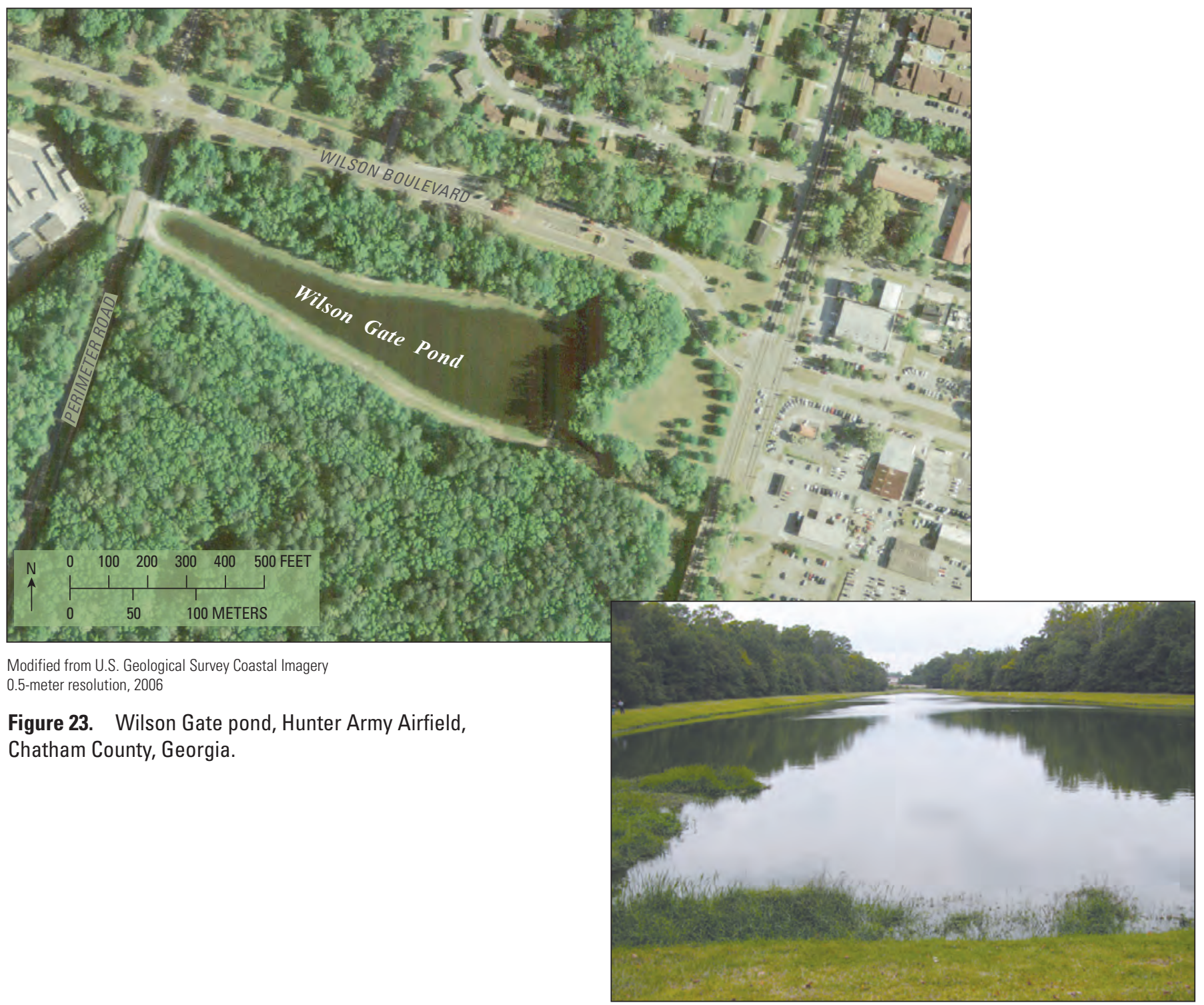

Figure 24. Wilson Gate pond from top of earthen dam looking westward, Hunter Army Airfield, Chatham County, Georgia. 


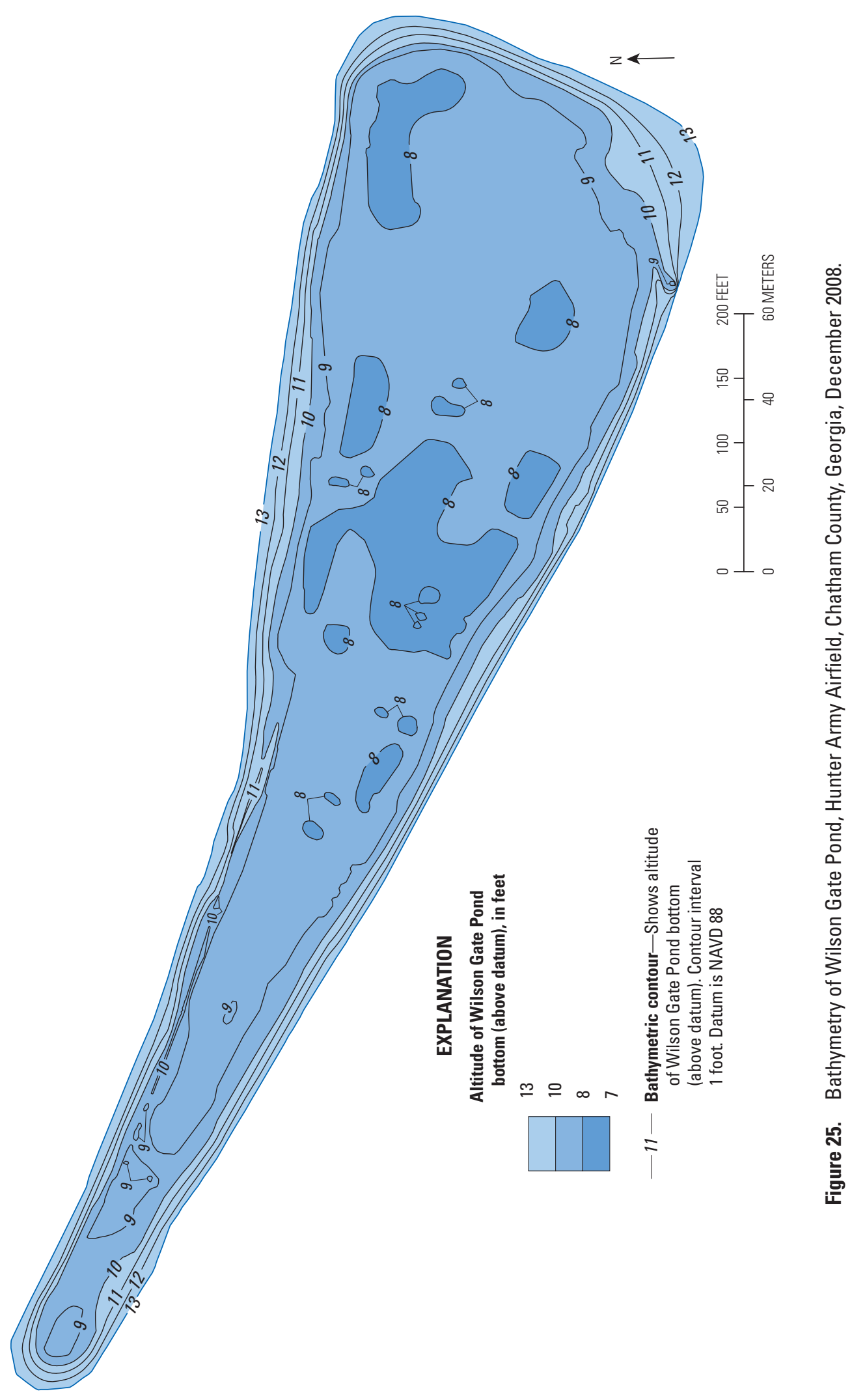



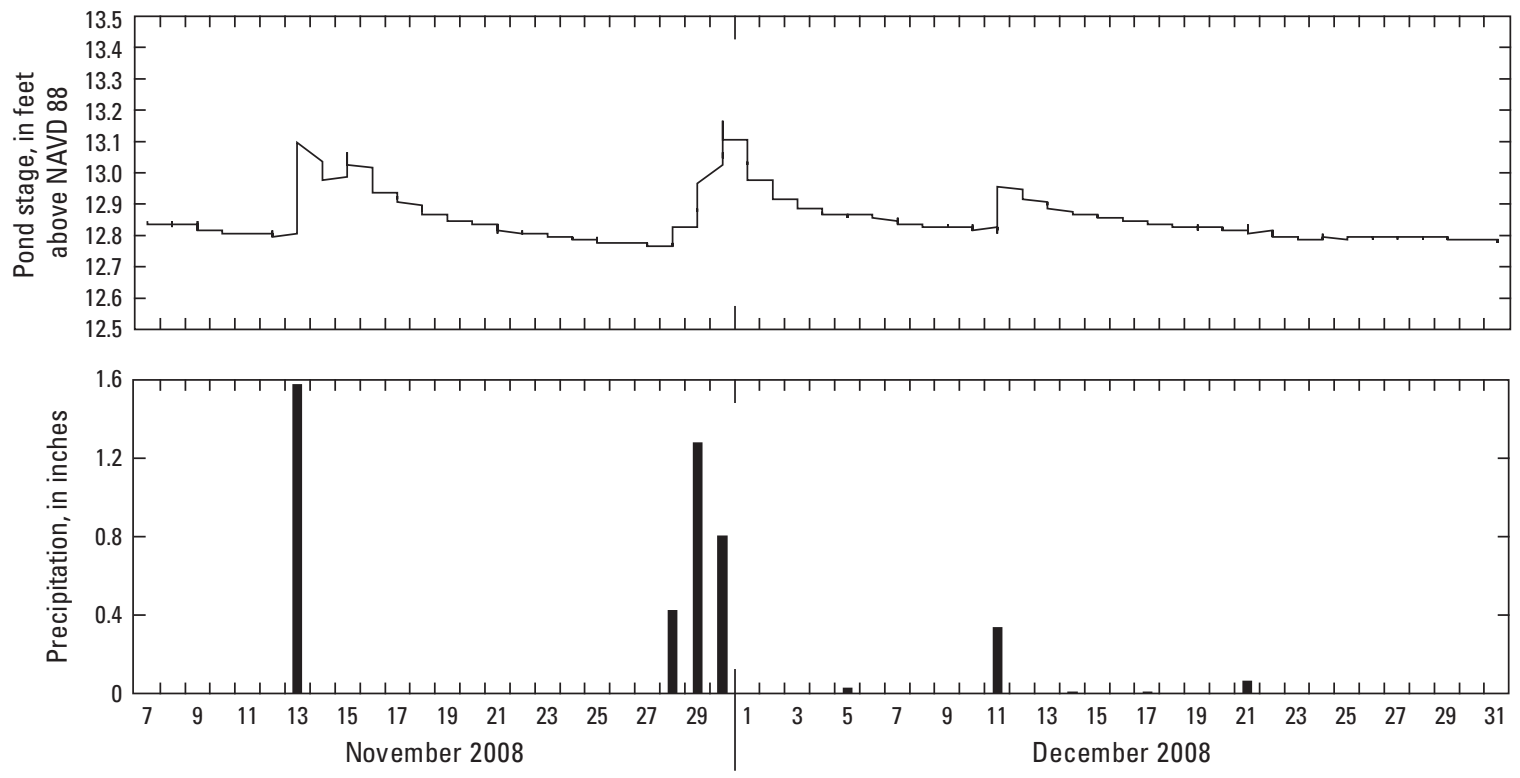

Figure 26. Stage and estimated daily total precipitation at Wilson Gate Pond, Hunter Army Airfield, Chatham County, Georgia, November-December 2008. Precipitation estimates based on regression analysis with Oglethorpe Lake. Stage recorded at 1-hour intervals.

Pond volume and area were estimated using a GIS and polynomial regression models for a range of pond stages (fig. 27). At the highest recorded stage of $13.22 \mathrm{ft}$ above NAVD 88, the volume of water stored in the pond was about 5.85 Mgal, covering a surface area of $202,266 \mathrm{ft}^{2}$, or 4.64 acres. At the lowest recorded stage of $12.88 \mathrm{ft}$ above NAVD 88, the volume of water in the pond was about $5.32 \mathrm{Mgal}$, covering a surface area of $190,310 \mathrm{ft}^{2}$, or 4.32 acres.

\section{Water Budget}

A simplified water budget was developed for Wilson Gate Pond based on daily pond stage, precipitation, and evaporation data collected during November 7-December 31, 2008 (fig. 28). Precipitation data were obtained from the stormwater site at HAAF (Russell Moncrief, U.S. Army, written commun., April 15, 2009). Because of several days of missing record at this site, precipitaton was estimated based on daily precipitation data at Oglethorpe Lake, about 1.5 miles to the northwest. Because some of the precipitation data were estimated, an error factor of 20 percent was assigned for water-budget computations, rather than the 15-percent factor assigned at Halstrum Pond and Oglethorpe Lake.

Daily computed Pnet at Wilson Gate Pond ranged from a low of -0.8 inch on November 7 , to a high of 1.54 inches on November 13 (fig. 28A). During the study period, precipitation was mostly limited to storms during November 13, November 28-30, and December 11, and daily evapotranspiration ranged from 0.005 to 0.08 inch. Daily values of Pnet were mostly negative, indicating more water was leaving the pond from evaporation than entering it from precipitation.
Exceptions occur when Pnet values were positive during the aforementioned rainfall events. Despite these rainfall events, there was a small cumulative loss in pond volume during the study period (fig. 29).
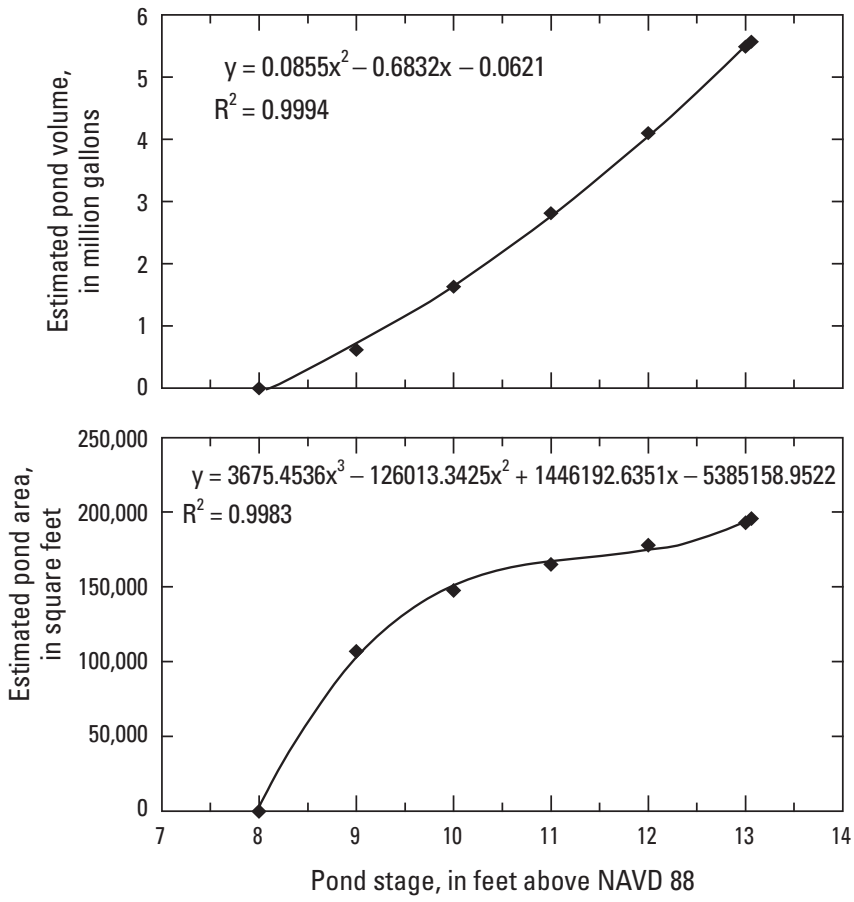

Figure 27. Relation of pond stage to computed volume and surface area, and regression fit of data, Wilson Gate Pond, Hunter Army Airfield, Chatham County, Georgia. 

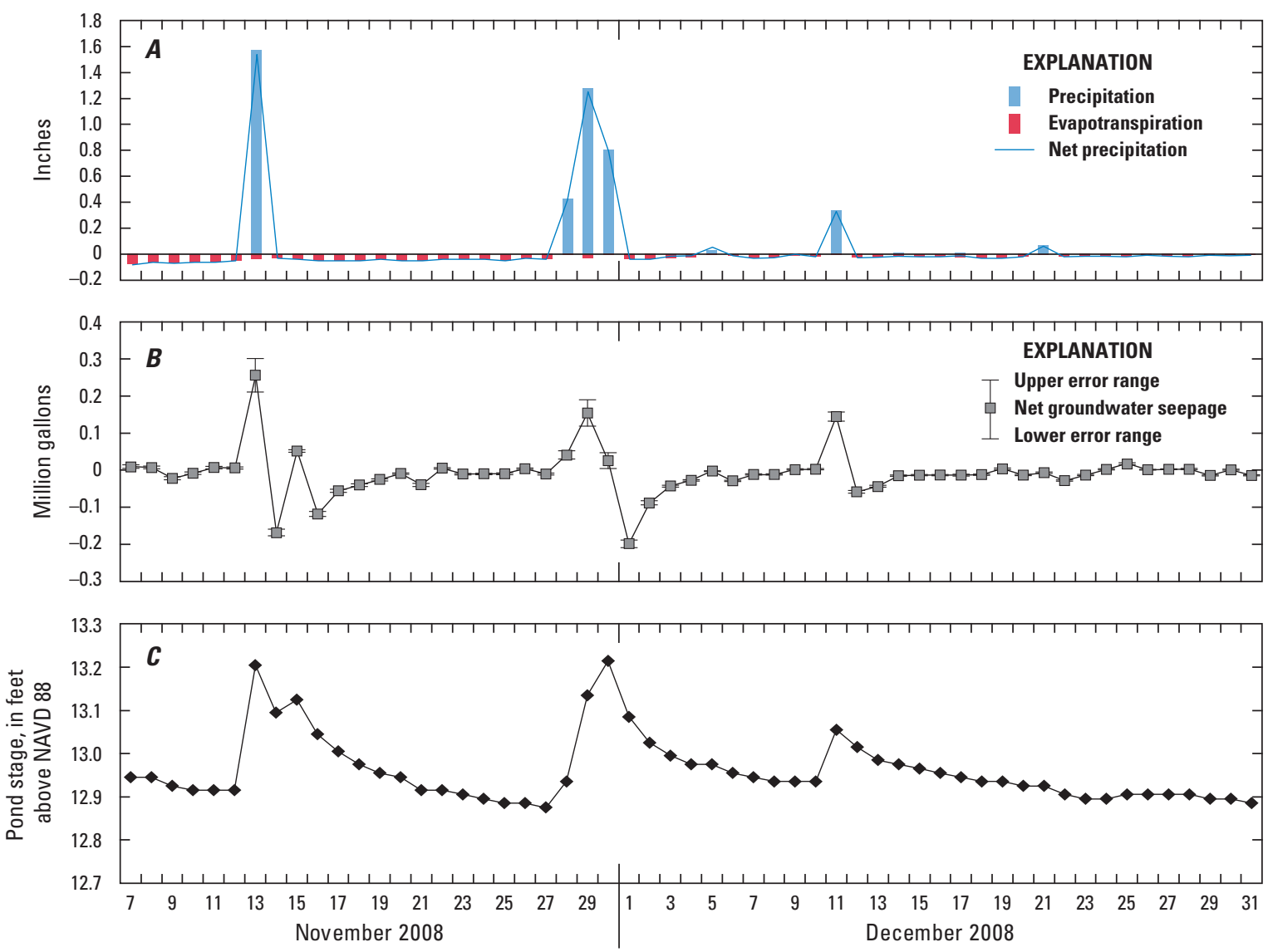

Figure 28. Hydrologic and climatic data at Wilson Gate Pond, Hunter Army Airfield, Chatham County, Georgia, and vicinity, November-December 2008. (A) Daily estimated precipitation and net precipitation at Halstrum Pond, and estimated daily evapotranspiration at the Bamboo Farm, Georgia Environmental Monitoring Site; $(B)$ net groundwater seepage; and $(C)$ pond stage.

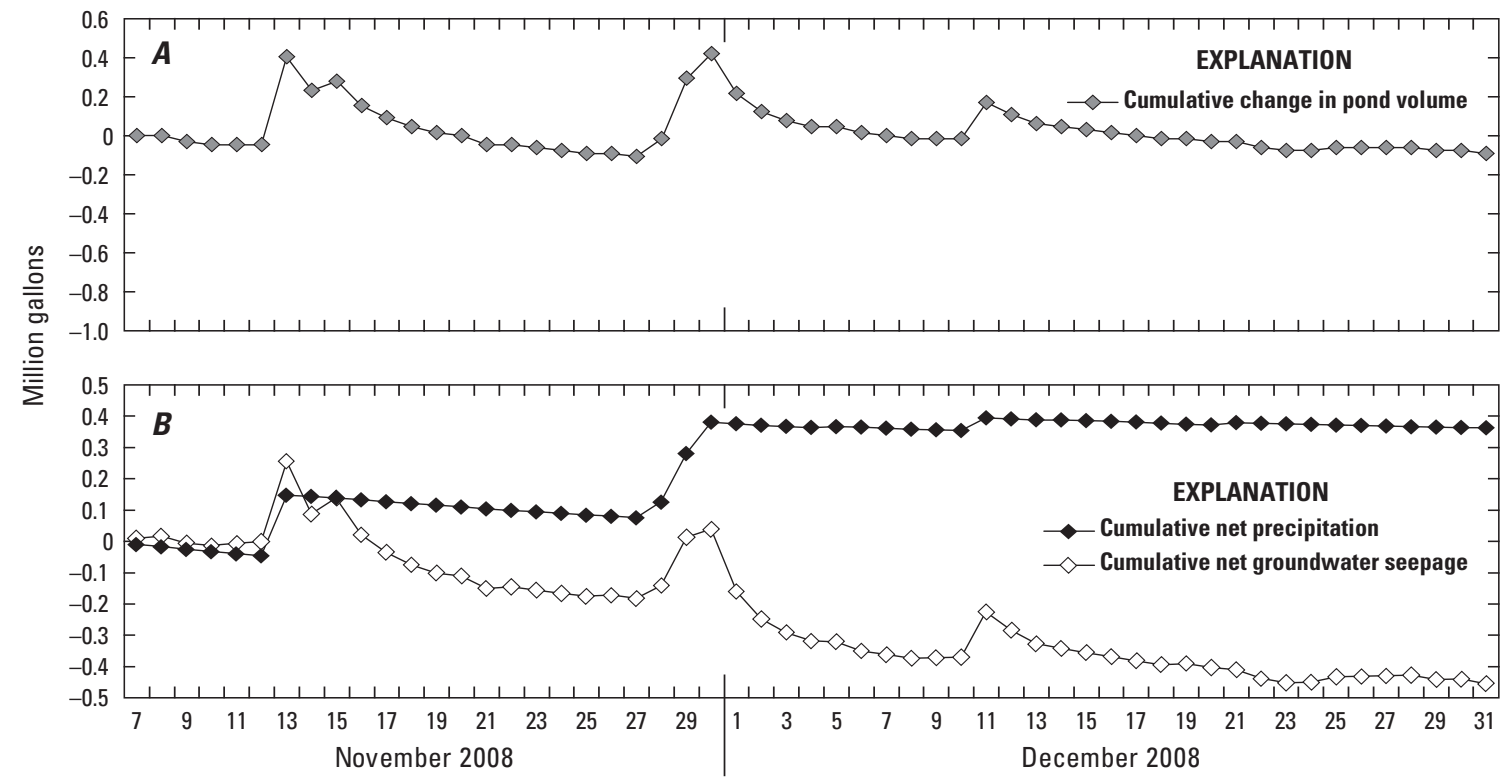

Figure 29. (A) Cumulative daily change in pond volume and $(B)$ net precipitation and net groundwater seepage, Wilson Gate Pond, Hunter Army Airfield, Chatham County, Georgia, November-December 2008. 
During November-December 2008, estimated daily Gnet was mostly negative, reflecting loss of pond volume, and ranged from -0.20 to $+0.26 \mathrm{Mgal}$ (fig. 28B). The largest daily Gnet gain (indicated by a positive value) occurred following rainstorms on November 13, and the largest loss (indicated by a negative value) occurred on December 1. During the 55-day study period, the cumulative Gnet volume was $-0.45 \mathrm{Mgal}$, or $-5.74 \mathrm{gal} / \mathrm{min}$, indicating a net loss to pond volume (fig. 29). Gnet inflows occurred following rainfall events, with the maximum daily value of $0.26 \mathrm{Mgal}$ on November 13 equivalent to a rate of $182 \mathrm{gal} / \mathrm{min}$. Some of the large Gnet gains following rainfall events could be attributed to stormwater inflow to the pond.

Uncertainty in Gnet estmates are due to combined errors associated with precipitation, evaporation, volume, and discharge computed using equation 2 . The largest error for daily Gnet estimates (0.04 Mgal) occurred November 13, following a large rainstorm of an estimated 1.58 inches (fig. 28B). Because a 20-percent error was assigned to precipitation at Wilson Gate Pond, the high rainfall resulted in a larger overall error range. The variation in Gnet error was smaller during periods of little or no precipitation at the pond.

An indication of rates of groundwater replenishment (positive Gnet) to pond volume is provided by evaluating rates following three rainfall periods on November 12-13, 28-30, and December 10-11 (fig. 29).

- During November 12-13, a 1.58-inch rainfall resulted in an increase in pond stage of $0.29 \mathrm{ft}$ and an increase in pond volume of about $0.45 \mathrm{Mgal}$. Total Gnet volume during this period was $0.26 \mathrm{Mgal}$, or $91 \mathrm{gal} / \mathrm{min}$.

- During November 27-30, 2.51 inches of precipitation resulted in an increase in pond stage of $0.34 \mathrm{ft}$, and an increase in pond volume of about $0.53 \mathrm{Mgal}$. Over the 3-day period, Gnet contributed a cumulative volume of $0.22 \mathrm{Mgal}$ (fig. 28B), at an average rate of $51 \mathrm{gal} / \mathrm{min}$.

- During December 10-11, 0.34 in of preciptiation resulted in an increase in pond stage of $0.12 \mathrm{ft}$, and an increase in pond volume of about $0.18 \mathrm{Mgal}$. During the 2-day period, Gnet contributed a cumulative volume of $0.15 \mathrm{Mgal}$ (fig. 28B), at an average rate of $51 \mathrm{gal} / \mathrm{min}$.

\section{Water Quality}

To assess water quality at Wilson Gate Pond, field properties (specific conductance, dissolved oxygen, temperature, and $\mathrm{pH}$ ) were measured at three discrete depths at the deepest part of the pond on April 21, 2009 (fig. 30). The deepest part of the pond is about $7 \mathrm{ft}$ deep; measurements were collected at 2, 4, and $6 \mathrm{ft}$. Values of $\mathrm{pH}$ and specific conductance show little variation with depth, with $\mathrm{pH}$ values ranging from 5.3 to 5.4 units and specific conductance ranging from 84 to $86 \mu \mathrm{s} / \mathrm{cm}$. Levels of $\mathrm{pH}$ did not meet the GaEPD standard of 6.0-8.5 for waters supporting warm-water species of fish (Georgia Department of Natural Resources, 2005).

Water temperature and dissolved oxygen slightly decrease with depth. Temperature was $24.4^{\circ} \mathrm{C}$ at a depth of $2 \mathrm{ft}$ and was $22.7^{\circ} \mathrm{C}$ at a depth of $6 \mathrm{ft}$. Dissolved oxygen decreases from $5.3 \mathrm{mg} / \mathrm{L}$ at a depth of $2 \mathrm{ft}$ to $4.3 \mathrm{mg} / \mathrm{L}$ at a depth of $6 \mathrm{ft}$, meeting the 4-mg/L GaEPD standard for water supporting warm-water species of fishes (Georgia Department of Natural Resources, 2005).

A composite water sample was collected on April 21, 2009, from the 2-, 4-, and 6-ft depth intervals (table 1). Analytical results indicate water from Wilson Gate Pond is low in dissolved solids and concentrations of most constituents. The water is fresh, with a chloride concentration of $12 \mathrm{mg} / \mathrm{L}$. Constituent concentrations are within U.S. Environmental Protection Agency primary and secondary drinking-water MCLs, with the exception of iron $(419 \mu \mathrm{g} / \mathrm{L})$, which exceeds the secondary MCL of $300 \mu \mathrm{g} / \mathrm{L}$. Although not a health hazard, when the iron concentration exceeds $300 \mu \mathrm{g} / \mathrm{L}$, iron staining of sidewalks and plumbing fixtures may occur. The reason for the high iron concentration is unknown but may be related to input from sources located offsite of HAAF.

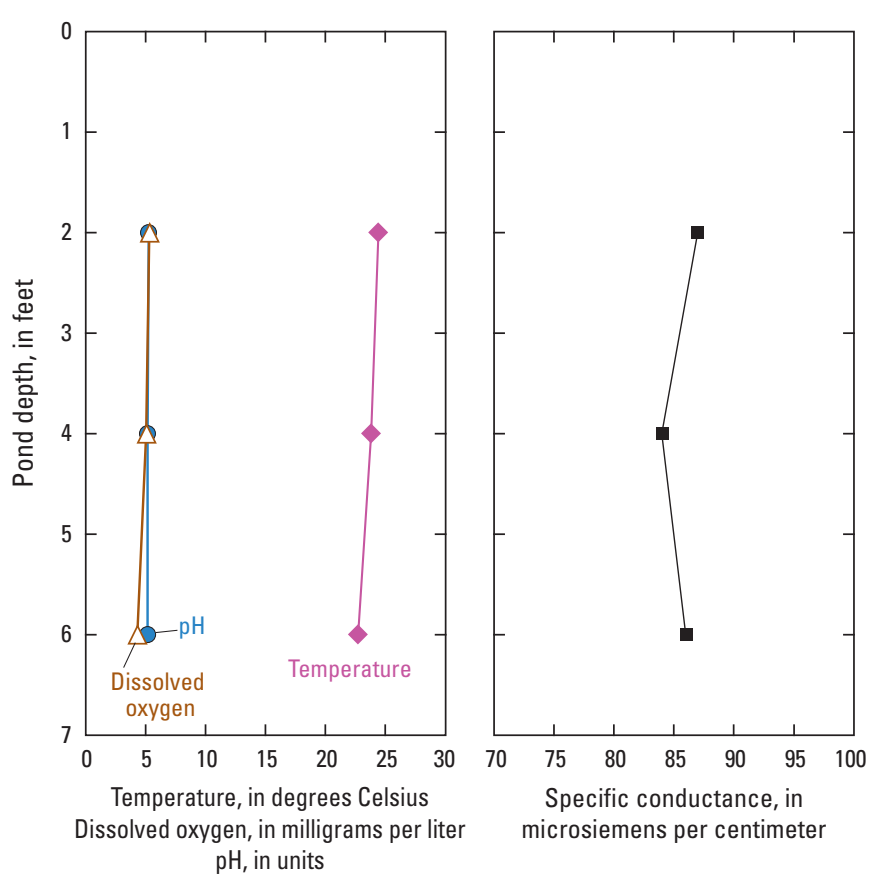

Figure 30. Water-quality profile at Wilson Gate Pond, Hunter Army Airfield, Chatham County, Georgia, April 21, 2009. 


\section{Golf Course Pond}

The golf course pond was constructed in 2000 and has a shallow unknown depth and area (fig. 31). The pond captures stormwater runoff from a drainage ditch along the eastern edge of the runway area (fig. 1) and is the only one of the four ponds not used for fishing. The pond discharges to a drainage ditch through a weir structure (fig. 32). Downstream from the weir, a continuous stormwater monitor operated by the U.S. Department of the Army at the location of USGS site 02203542 measures precipitation and water-quality properties during storm events.

Area and depth of the golf course pond were not delineated because streamflow records were used as a basis for evaluation and a detailed water budget analysis was not required. A report titled, "Golf Course Irrigation System Source Water Feasibility Evaluation” (U.S. Army Center for Heath Promotion and Preventative Medicine, 2008) indicated that the pond was designed to retain approximately 4.6 Mgal of surface water and stormwater. The report further stated that beaver dams obstructing the discharge weir had backed up water to levels $3 \mathrm{ft}$ higher than designed, increasing the volume of water stored to about 7.4 Mgal. The same report indicated that the pond was discharging during drought conditions, suggesting it was fed by "groundwater seeps." Measurements taken downstream from the weir during November 2007 and January 2008 indicated water was discharging from the pond at rates of 1-1.25 Mgal/d, or 694-868 gal/min (U.S. Army Center for Heath Promotion and Preventative Medicine, 2008).

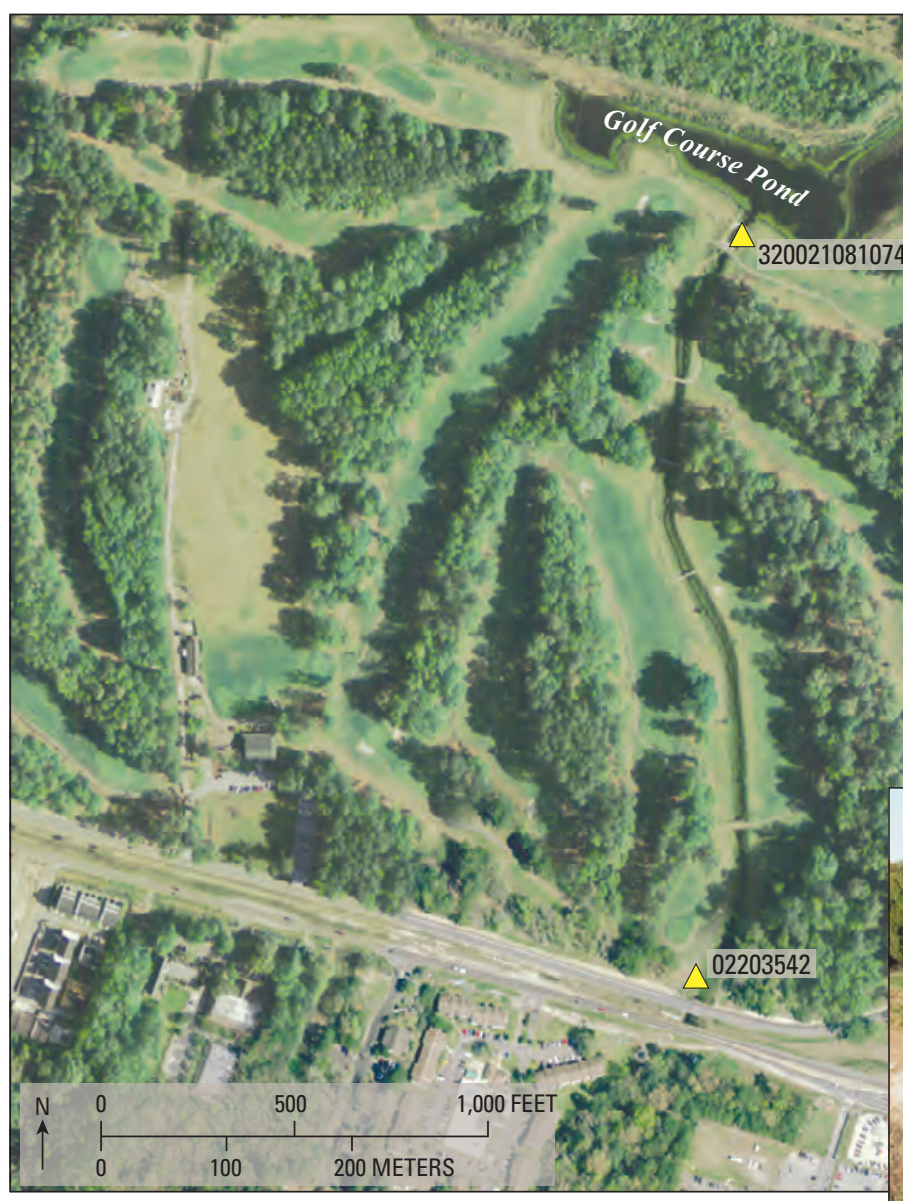

Modified from U.S. Geological Survey Coastal Imagery 0.5-meter resolution, 2006

\section{EXPLANATION}

$\triangle 02203542$ Surface-water monitoring site and identification
Figure 31. Golf course pond, Hunter Army Airfield, Chatham County, Georgia. 


\section{Streamflow}

The USGS collected 36 periodic streamflow measurements, generally during storm events, at Harmon Canal (site number 02203542) located about 2,150 ft downstream from the golf course pond during March 1979-September 1987 (figs. 31, 33). During this period, streamflow ranged from $282.8 \mathrm{gal} / \mathrm{min}$ in March 1979, to 77,647.8 gal $/ \mathrm{min}$ in September 1987 , with a median value of $23,339.2 \mathrm{gal} / \mathrm{min}$ (table 2 ). The percentile of a data population provides an indication of the frequency that a specified value is exceeded. For example, the 10th percentile is the value that is higher than 10 percent of the data population, or, alternatively, is exceeded by 90 percent of the population. During 1979-87, streamflow exceeded $6,171.4 \mathrm{gal} / \mathrm{min} 90$ percent of the time, as indicated by the 10th percentile. It is important to note that these measurements targeted higher stormflow values and that average monthly streamflow would be lower because non-storm base-flow periods are included.

To provide a more recent and seasonal indication of the amount of available water discharging from the golf course pond, a continuous streamflow monitoring site was established about $25 \mathrm{ft}$ downstream from the weir in February 2009.

The site monitors stream stage on a continuous basis, which provides data needed to estimate streamflow based on a relation or "rating" of stage and periodic discharge measurements.

Streamflow data for February-July 2009 are shown in figure 34. A comparison of field streamflow measurements to values generated by the rating curve indicates an approximate error range of 30 percent from the measured value (Anthony J. Gotvald, U.S. Geological Survey, oral commun., August 6, 2009).

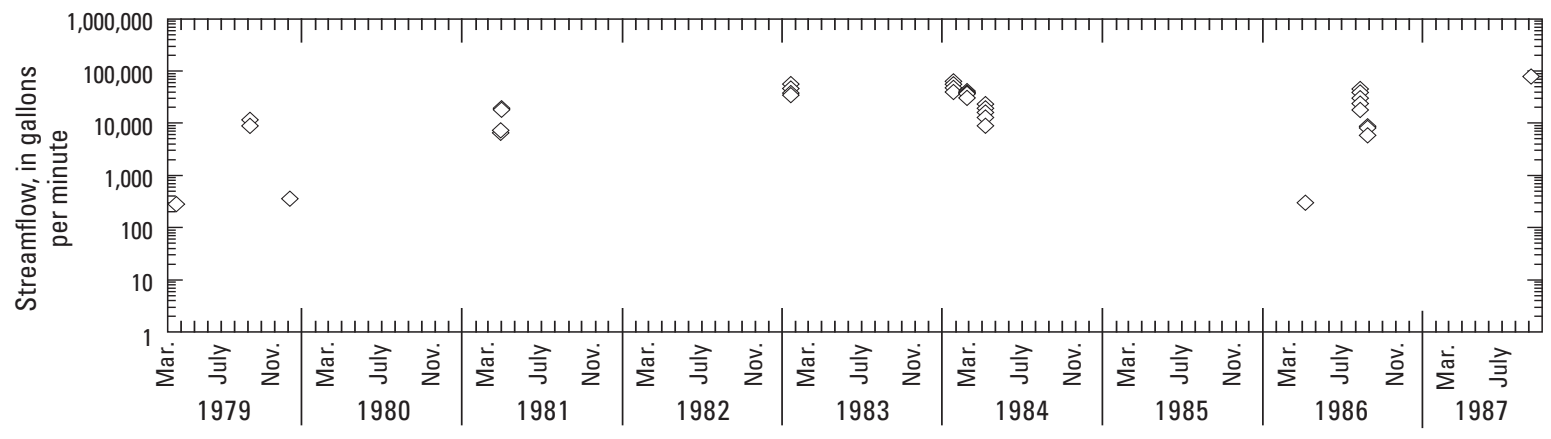

Figure 33. Periodic streamflow at site 02203542, Harmon Canal, Hunter Army Airfield, Chatham County, Georgia, 1979-87.

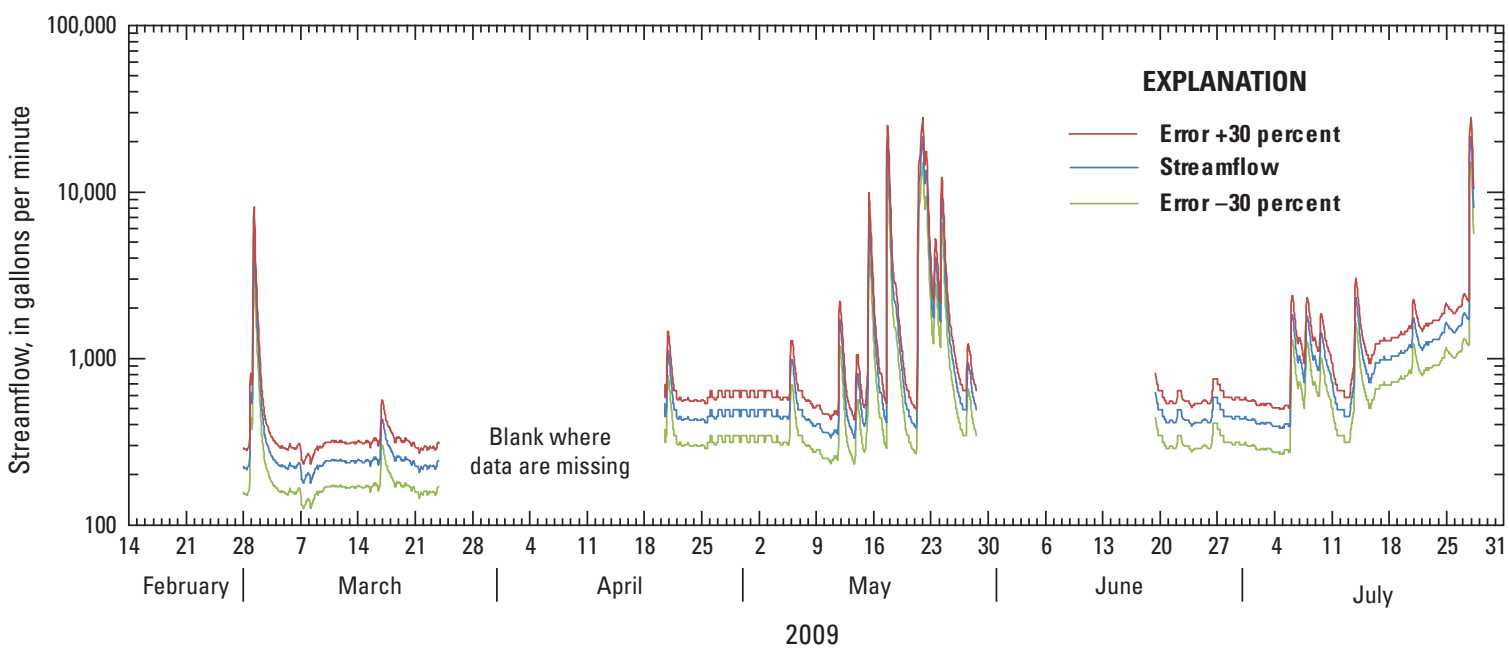

Figure 34. Hourly streamflow at golf course pond, Hunter Army Airfield, Chatham County, Georgia, February-July 2009. 
During February-July 2009, streamflow at the golf course pond ranged from about 180 to $21,543.9 \mathrm{gal} / \mathrm{min}$, with a median of $448.8 \mathrm{gal} / \mathrm{min}$ (fig. 34; table 2). Streamflow exceeded $237.9 \mathrm{gal} / \mathrm{min} 90$ percent of the time, as indicated by the 10th percentile (table 2). Average daily discharge ranged from $347.3 \mathrm{gal} / \mathrm{min}$ in March, to $1,700.6 \mathrm{gal} / \mathrm{min}$ in May. A longer period of data collection could provide a better statistical characterization for this site based on a wider range of climatic conditions.

\section{Water Quality}

To assess water quality at golf course pond, a water sample was collected and field properties (specific conductance, dissolved oxygen, temperature, and $\mathrm{pH}$ ) were measured at the mouth of the discharge weir on April 22, 2009. Water discharging through the weir had a temperature of $21.3^{\circ} \mathrm{C}$, a specific conductance of $105 \mu \mathrm{S} / \mathrm{cm}$ at $25^{\circ} \mathrm{C}$, and a $\mathrm{pH}$ of 6.0 (table 1). Dissolved oxygen was $3.8 \mathrm{mg} / \mathrm{L}$, which is below the 4-mg/L GaEPD standard for water supporting warm-water species of fishes (Georgia Natural Resources, 2005).

Analytical results indicate that water from the golf course pond is low in dissolved solids and concentrations of most constituents. The water is fresh, with a chloride concentration of $7.09 \mathrm{mg} / \mathrm{L}$. Constituent concentrations are within U.S. Environmental Protection Agency primary and secondary drinking-water MCLs.

Table 2. Statistical summary of streamflow data at golf course pond, Hunter Army Airfield, Chatham County, Georgia, 1979-87 and 2009.

$[-$, no data $]$

\begin{tabular}{|c|c|c|c|c|}
\hline & \multicolumn{2}{|c|}{ Periodic data March 1979-September 1987} & \multicolumn{2}{|c|}{ Continuous data February-July 2009} \\
\hline & $\begin{array}{l}\text { Cubic feet } \\
\text { per second }\end{array}$ & $\begin{array}{c}\text { Gallons } \\
\text { per minute }\end{array}$ & $\begin{array}{l}\text { Cubic feet } \\
\text { per second }\end{array}$ & $\begin{array}{c}\text { Gallons } \\
\text { per minute }\end{array}$ \\
\hline Number of values & 36 & 36 & 2,414 & 2,414 \\
\hline Average & 59.92 & $26,892.46$ & 2.15 & 964.63 \\
\hline Minimum & 0.63 & 282.76 & 0.40 & 179.53 \\
\hline 10th Percentile & 13.75 & $6,171.43$ & 0.53 & 237.88 \\
\hline 25th Percentile & 19.78 & $8,875.63$ & 0.87 & 390.48 \\
\hline 50th Percentile & 52.00 & $23,339.21$ & 1.00 & 448.83 \\
\hline 75th Percentile & 86.23 & $38,700.45$ & 2.10 & 942.55 \\
\hline 90th Percentile & 114.00 & $51,166.73$ & 3.50 & $1,570.91$ \\
\hline Maximum & 173.00 & $77,647.76$ & 48.00 & $21,543.89$ \\
\hline \multicolumn{5}{|c|}{ Monthly average } \\
\hline January & 105.2 & 47,195 & - & - \\
\hline February & 81.7 & 36,687 & - & - \\
\hline March & 10.4 & 4,687 & 0.8 & 347 \\
\hline April & 32.7 & 14,675 & 1.1 & 487 \\
\hline May & - & - & 3.8 & 1,701 \\
\hline June & - & - & 1.0 & 453 \\
\hline July & - & - & 2.6 & 1,169 \\
\hline August & 49.4 & 22,161 & - & - \\
\hline September & 72.8 & 32,675 & - & - \\
\hline
\end{tabular}




\section{Water-Supply Potential}

To meet the growing water demand at HAAF, the four ponds are being considered as possible sources of supplemental irrigation supply for several locations at HAAF. The water-supply potential of the ponds is determined by available volume, rates of Gnet and Pnet, and water quality. In addition, because some of the ponds are stocked and used for fishing, changes in stage that affect fish habitats need to be considered.

An indication of the volume of water available for irrigation supply at Oglethorpe Lake and Halstrum and Wilson Gate Ponds during dry climatic conditions is provided by computing the rate of depletion of pond volume for various discharge, Pnet, and Gnet rates (table 3). Because the ponds will serve as irrigation sources mostly during dry periods, evaporation and precipitation estimates are based on the long-term average values for July from the Savannah International Airport site (fig. 2). Average total precipitation for July during 1971-2000 was 6.23 inches, and average monthly evaporation for July during 1965-2003 was 8.49 inches, resulting in a monthly Pnet of -2.26 inches. Rates of evaporative loss at each pond were adjusted to account for changes in pond surface area, with decreasing stage as pond volume is depleted. To provide conservative estimates of rates of depletion, the average estimated Gnet at each of the ponds for the study period was used for the evaluation; thus, greater quantities of water may be available from the ponds. This analysis assumes that there is no precipitation during the pumping period, that evaporation remains constant, and that rates of Gnet remain constant as pond stage is lowered. The latter assumption likely results in an underestimation of the amount of available water because a previous study by Clarke and Abu Rumman (2004) demonstrated that simulated Gnet rates increase in response to lowered pond stage.

Irrigation demands are often quantified in terms of application rates per acre, usually expressed in inches per acre. According to the Georgia Cooperative Extension Service (Landry, 2009), "In general, most turf grasses grown in Georgia use about 1 inch of water per week to maintain normal growth and color. But under some conditions such as shallow rooting and high nitrogen levels, water use may be 2 inches per week." A 1-inch application over 1 acre would require $57 \mathrm{gal} / \mathrm{min}$ over an 8 -hour period; a 2 -inch application would require $114 \mathrm{gal} / \mathrm{min}$. The following sections describe depletion of pond volume for discharge rates of 250, 500, and $1,000 \mathrm{gal} / \mathrm{min}$ for an 8-hour per day $(\mathrm{hr} / \mathrm{d})$ pumping period. During an 8-hour period, pumping at a rate of $250 \mathrm{gal} / \mathrm{min}$ would enable application of 1 inch over $4.4 \mathrm{acres}, 500 \mathrm{gal} / \mathrm{min}$ over 8.8 acres, and $1,000 \mathrm{gal} / \mathrm{min}$ over 17.6 acres.

Table 3. Summary of pond volume and net groundwater seepage and pond-volume depletion rates for Oglethorpe Lake and Halstrum and Wilson Gate Ponds, Hunter Army Airfield, Chatham County, Georgia.

[Depletion rates computed assuming an 8-hour per day irrigation period and long-term average climatic conditions during July and average net groundwater seepage during November-December 2008]

\begin{tabular}{|c|c|c|c|c|c|c|c|}
\hline \multirow{2}{*}{ Site } & \multirow{2}{*}{$\begin{array}{c}\text { Year } \\
\text { constructed }\end{array}$} & \multirow{2}{*}{ Acres } & \multirow{2}{*}{$\begin{array}{l}\text { Maximum } \\
\text { volume } \\
\text { (million } \\
\text { gallons) }\end{array}$} & \multirow{2}{*}{$\begin{array}{c}\text { Average net } \\
\text { groundwater seepage, } \\
\text { November-December } 2008 \\
\text { (gallons per minute) }\end{array}$} & \multicolumn{3}{|c|}{$\begin{array}{l}\text { Number of days for depletion of } \\
\text { storage at pumping rate }\end{array}$} \\
\hline & & & & & $\begin{array}{l}250 \text { gallons } \\
\text { per minute }\end{array}$ & $\begin{array}{l}500 \text { gallons } \\
\text { per minute }\end{array}$ & $\begin{array}{l}1,000 \text { gallons } \\
\text { per minute }\end{array}$ \\
\hline Oglethorpe Lake & 1985 & 9.5 & 7.28 & 3 & 58 & 31 & 16 \\
\hline Halstrum Pond & 1968 & 4.6 & 12.8 & 19 & 130 & 60 & 29 \\
\hline
\end{tabular}




\section{Oglethorpe Lake}

The quality of water from Oglethorpe Lake is fresh, with a chloride concentration of $3.85 \mathrm{mg} / \mathrm{L}$. During the November-December 2008 study period, available volume in Oglethorpe Lake ranged from 6.26 to $7.28 \mathrm{Mgal}$, and Gnet averaged about $3 \mathrm{gal} / \mathrm{min}$, with higher inflows following rainfall events. Assuming long-term average climatic conditions for July and an $8 \mathrm{hr} / \mathrm{d}$ pumping period, total depletion of pond volume in Oglethorpe Lake would occur after 16 days at a pumping rate of $1,000 \mathrm{gal} / \mathrm{min}$, after 31 days at a pumping rate of $500 \mathrm{gal} / \mathrm{min}$, and after 58 days at a pumping rate of $250 \mathrm{gal} / \mathrm{min}$ (fig. 35). A limitation on the quantity of water available in Oglethorpe Lake is leakage through the dam, with a maximum rate of $280 \mathrm{gal} / \mathrm{min}$ measured in November 2008 .

\section{Halstrum Pond}

The quality of water from Halstrum Pond is fresh, with a chloride concentration of $6.52 \mathrm{mg} / \mathrm{L}$. During the NovemberDecember 2008 study period, available volume in Halstrum Pond ranged from 10.8 to $12.8 \mathrm{Mgal}$, and Gnet averaged about $19 \mathrm{gal} / \mathrm{min}$, with higher Gnet inflows following rainfall events. Assuming long-term average climatic conditions for July and an $8 \mathrm{hr} / \mathrm{d}$ pumping period, total depletion of pond volume in Halstrum Pond would occur after 29 days at a pumping rate of $1,000 \mathrm{gal} / \mathrm{min}$, after 60 days at a pumping rate of $500 \mathrm{gal} / \mathrm{min}$, and after 130 days at a pumping rate of $250 \mathrm{gal} / \mathrm{min}$ (fig. 36).

\section{Wilson Gate Pond}

The quality of water from Wilson Gate Pond is fresh, with a chloride concentration of $12 \mathrm{mg} / \mathrm{L}$. During the November-December 2008 study period, available volume in Wilson Gate Pond ranged from 5.32 to $5.85 \mathrm{Mgal}$, and Gnet averaged -5.74 gal $/ \mathrm{min}$; however, Gnet inflows occurred following rainfall events. Assuming long-term average climatic conditions for July and an $8 \mathrm{hr} / \mathrm{d}$ pumping period, total depletion of pond volume in Wilson Gate Pond would occur after 13 days at a pumping rate of $1,000 \mathrm{gal} / \mathrm{min}$, after 24 days at a pumping rate of $500 \mathrm{gal} / \mathrm{min}$, and after 44 days at a pumping rate of $250 \mathrm{gal} / \mathrm{min}$ (fig. 37).

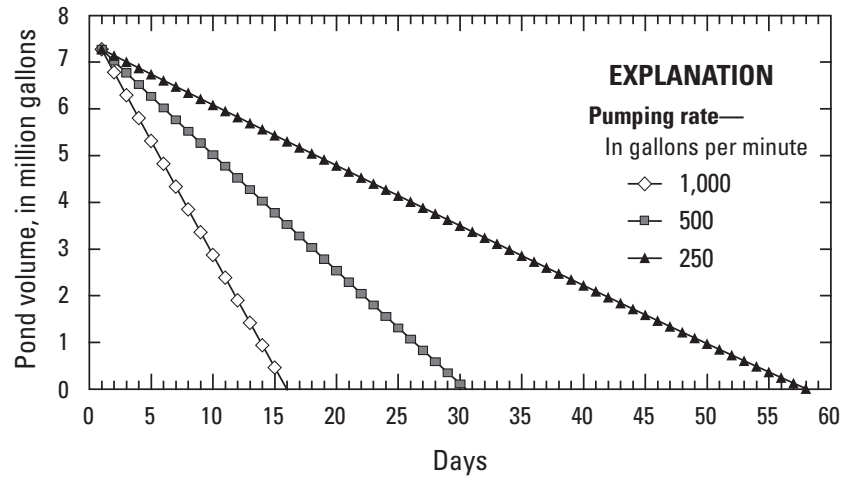

Figure 35. Hypothetical rate of depletion of pond volume at pumping rates of $1,000,500$, and 250 gallons per minute for 8 hours per day for long-term climatic conditions during July at Oglethorpe Lake, Hunter Army Airfield, Chatham County, Georgia.

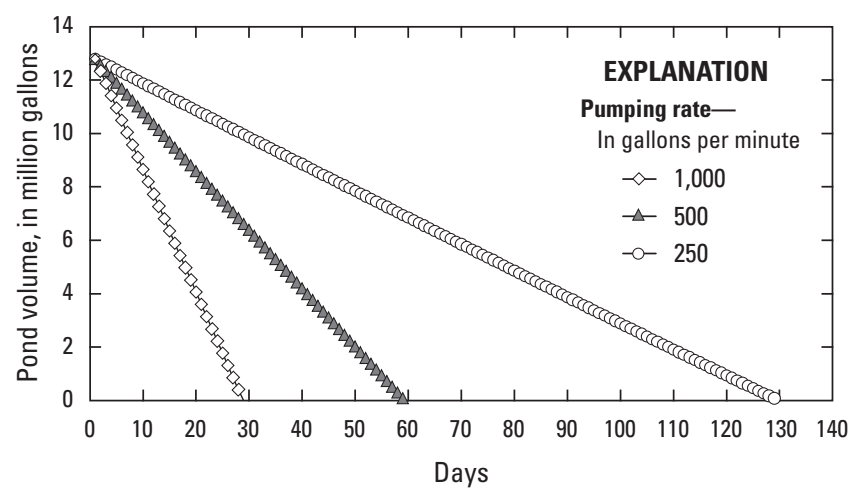

Figure 36. Hypothetical rate of depletion of pond volume at pumping rates of $1,000,500$, and 250 gallons per minute for 8 hours per day for long-term climatic conditions during July at Halstrum Pond, Hunter Army Airfield, Chatham County, Georgia.

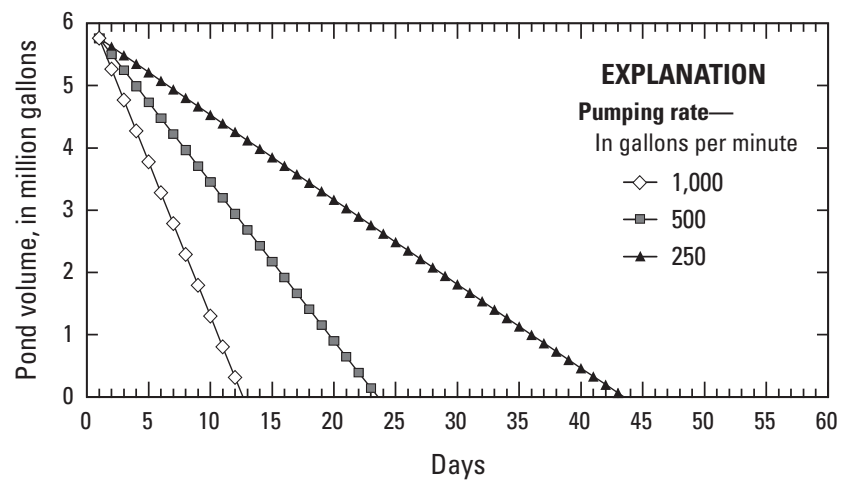

Figure 37. Hypothetical rate of depletion of pond volume at pumping rates of $1,000,500$, and 250 gallons per minute for 8 hours per day for long-term climatic conditions during July at Wilson Gate Pond, Hunter Army Airfield, Chatham County, Georgia. 


\section{Golf Course Pond}

Currently (2009), irrigation water at the golf course pond is derived from the HAAF potable water system, which is supplied by wells completed in the Upper Floridan aquifer. Average reported water use at the golf course during 2005-2007, a period of below-normal precipitation, is listed in table 4. Maximum monthly usage generally occurs during March-May and July-October, with a maximum average of $7.91 \mathrm{Mgal}(0.26 \mathrm{Mgal} / \mathrm{d})$ used during the month of July. Assuming an 8-hour daily irrigation period, the average pumping rate required to meet the demand during March-May and July-October would range from 214 to $531 \mathrm{gal} / \mathrm{min}$. Average daily golf course water-use data for 2005-07 and periodic streamflow measurements during $1979-87$ and 2009 are shown in figure 38 .

The quality of water from the golf course pond is fresh, with a chloride concentration of $7.09 \mathrm{mg} / \mathrm{L}$. During February-July 2009, streamflow downstream from the golf course pond exceeded $237.9 \mathrm{gal} / \mathrm{min} 90$ percent of the time (table 2). Daily average streamflow ranged from $347.3 \mathrm{gal} / \mathrm{min}$ in March to 1,700.6 gal/min during May, with higher values caused by storm events. The average daily streamflow during February-July 2009 exceeded average daily water use at the golf course during the same months in 2005-07 (fig. 38). In addition, periodic streamflow measurements during 1979-87 exceeded average 2005-07 golf course water use during January-April, August, September, and December, exceeding $6,171 \mathrm{gal} / \mathrm{min} 90$ percent of the time.

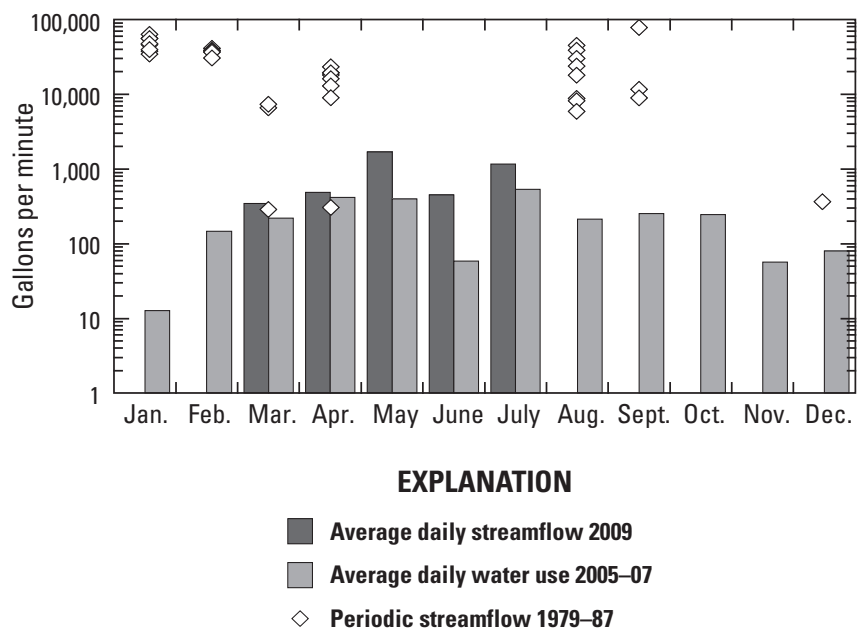

Figure 38. Average daily golf course water use, 2005-07, periodic streamflow measurements during 1979-87, and average daily streamflow during MarchJuly 2009, golf course pond, Hunter Army Arifield, Chatham County, Georgia. 


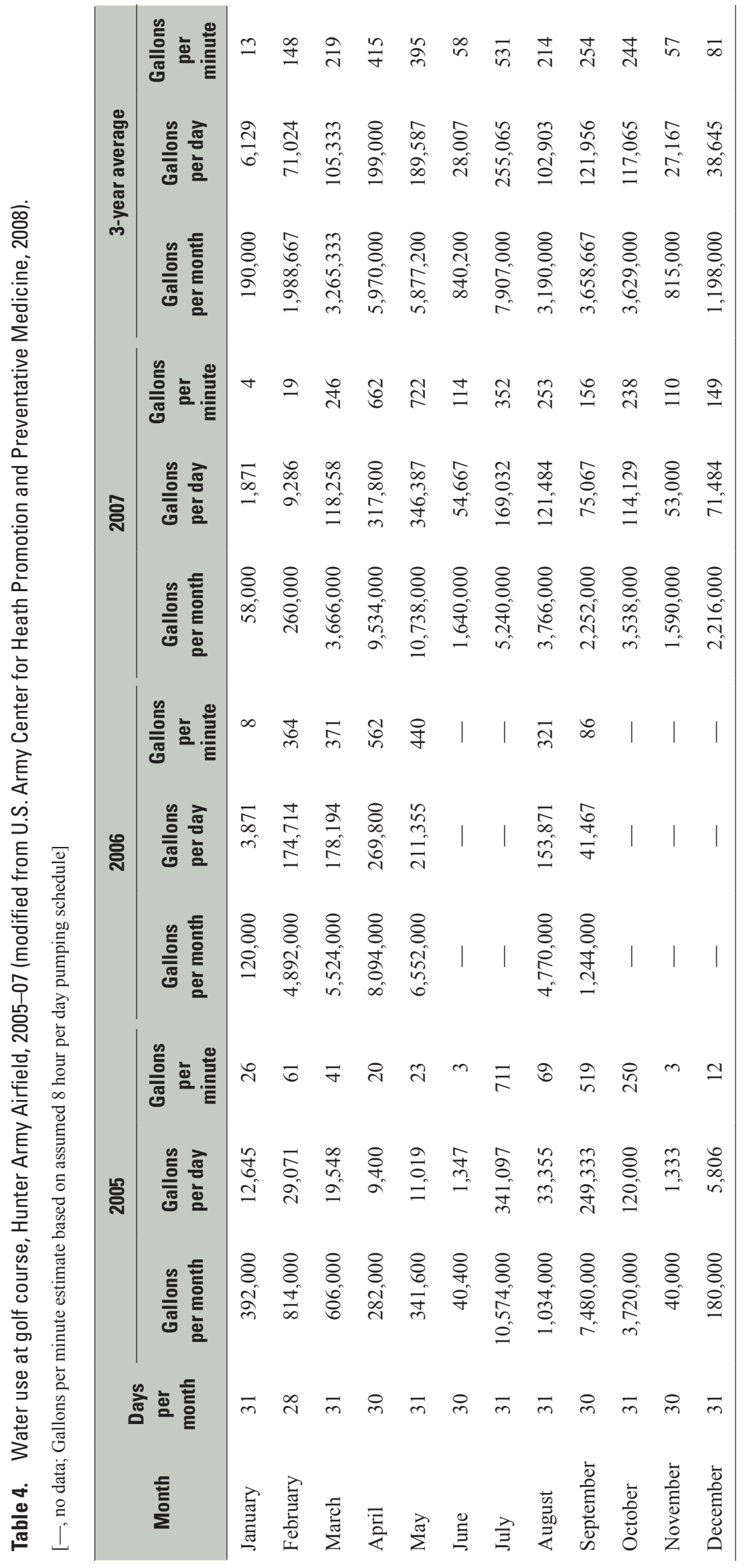




\section{Summary}

Water from all four ponds at HAAF is fresh, with chloride concentrations below 12 milligrams per liter $(\mathrm{mg} / \mathrm{L})$. With the exception of iron in Wilson Gate Pond, constituent concentrations are below U.S. Environmental Protection Agency primary and secondary maximum contaminant levels (MCLs) for drinking water. Water in Wilson Gate Pond contains an iron concentration of 419 micrograms per liter $(\mu \mathrm{g} / \mathrm{L})$, which exceeds the secondary MCL of $300 \mu \mathrm{g} / \mathrm{L}$. Although not a health hazard, when the iron concentration exceeds $300 \mu \mathrm{g} / \mathrm{L}$, iron staining of sidewalks and plumbing fixtures may occur. Levels of dissolved oxygen were below the Georgia Environmental Protection Divison standard of $4 \mathrm{mg} / \mathrm{L}$ for water supporting warm-water fishes at deeper depths in Oglethorpe Lake, Wilson Gate Pond, and Halstrum Pond, and in the composite sample at the golf course pond.

Quantitites of freshwater from the four ponds are limited by pond volume and net groundwater seepage (Gnet) rates during periods of low precipitation. Pond volume for the observed range of stage was determined for Oglethorpe Lake, Halstrum Pond, and Wilson Gate Pond. Storage volume ranged from 5.32 to 12.8 million gallons (Mgal), with the greatest storage volume available in Halstrum Pond. During the November-December 2008 period, used to compute water budgets at the three ponds, average Gnet ranged from -5.74 gallons per minute (gal/min) at Wilson Gate Pond, indicating net loss in seepage, to $19 \mathrm{gal} / \mathrm{min}$ at Halstrum Pond, indicating a net gain in seepage. During several periods of stage recovery, daily Gnet rates were higher than the 2-month average, with the highest rates of 178-424 gal/min occurring during limited periods following major rainfall events. More typical Gnet rates were $23 \mathrm{gal} / \mathrm{min}$ in Halstrum Pond, $51-91 \mathrm{gal} / \mathrm{min}$ in Wilson Gate Pond, and 39-223 gal $/ \mathrm{min}$ in Oglethorpe Lake. Some of the large Gnet gains following rainfall events could be attributed to stormwater inflow to the pond.

An indication of the volume of water available for irrigation supply at Oglethorpe Lake and Halstrum and Wilson Gate Ponds was provided by computing the rate of depletion of pond volume for a variety of withdrawal rates based on long-term average July precipitation and evaporation and the lowest estimated Gnet rate at each pond. Withdrawal rates of $1,000,500$, and $250 \mathrm{gal} / \mathrm{min}$, were projected over an 8-hour daily pumping period. At a withdrawal rate of $1,000 \mathrm{gal} / \mathrm{min}$, available pond volume would be depleted in
13 days at Wilson Gate Pond, 16 days at Oglethorpe Lake, and 29 days at Halstrum Pond. Pumping at a rate of $500 \mathrm{gal} / \mathrm{min}$ would deplete pond volume in Oglethorpe Lake in 31 days, in Halstrum Pond in 60 days, and in Wilson Gate Pond in 24 days. Pond volume would be depleted while withdrawing at a rate of $250 \mathrm{gal} / \mathrm{min}$ in 44 days at Wilson Gate Pond, 58 days at Oglethorpe Lake, and 130 days at Halstrum Pond. This analysis assumes that there is no precipitation during the pumping period, that evaporation remains constant, and that rates of Gnet remain constant as pond stage is lowered. The effect of stage changes resulting from withdrawal on fish populations in the ponds would need to be considered when developing a water-withdrawal plan for each pond.

Accuracy of Gnet estimates are limited by the accuracy of each water-budget component. Field measurements have an associated error depending on the method of measurement; total Gnet error is an accumulation of the errors of the various measurements. Note that different climatic conditions and pumping rates would influence the rate of pond-volume depletion, and that reducing pond stage beyond the range of observed test conditions during November-December 2008 also increases rates of net groundwater seepage into the ponds. Despite these limitations, the aforementioned analysis gives some indication of the sustainability of pumping the ponds during dry summer conditions.

The water-supply potential at the golf course pond was assessed by measuring flow downstream from the pond during February-July 2009, and examining historic stormflow measurements collected during 1979-87. These measurements indicate that streamflow during these periods exceeded average daily water use at the golf course pond during 2005-07, a period of below-normal precipitation when water demand would be expected to be higher. Assuming an 8-hour daily irrigation period, the average discharge rate required to meet golf course water demand during peak demand months of March-May and July-October exceeds $200 \mathrm{gal} / \mathrm{min}$, with the greatest rate of $531 \mathrm{gal} / \mathrm{min}$ during July. During February-July 2009, daily average streamflow downstream from the golf course pond exceeded $238 \mathrm{gal} / \mathrm{min} 90$ percent of the time. Daily average streamflow ranged from $347 \mathrm{gal} / \mathrm{min}$ in March to $1,700 \mathrm{gal} / \mathrm{min}$ during May, with higher values due to storm events. Periodic streamflow measurements during $1979-87$ exceeded $6,171 \mathrm{gal} / \mathrm{min} 90$ percent of the time; however, these measurements are skewed toward higher stormflow values, and average monthly streamflow would be lower because non-storm base-flow periods are included. 


\section{Selected References}

Clarke, J.S., and Abu Rumman, Malek, 2004, Pond-aquifer flow and water availability in the vicinity of two coastal area seepage ponds, Glynn and Bulloch Counties, Georgia: U.S. Geological Survey Scientific Investigations Report 2004-5260, 70 p., accessed October 15, 2009, at http://pubs.usgs.gov/sir/2004/5260/.

Clarke, J.S., Hacke, C.M., and Peck, M.F., 1990, Geology and groundwater resources of the coastal area of Georgia: Georgia Geologic Survey Bulletin 113, 106 p.

Georgia Automated Environmental Monitoring Network, 2009, Bamboo Farm and Coastal Gardens, The University of Georgia, Savannah, Chatham County, Georgia, accessed January 6, 2009, at http://www.griffin.uga.edu/aemn/cgi-bin/ AEMN.pl? site $=G A S A$.

Georgia Department of Natural Resources, 2005, Rules and regulations for water quality control, chapter 391-3-6, revised November 2005, accessed October 23, 2009, at http://www.epa.gov/waterscience/standards/wqslibrary/ ga/ga_4_wqs.pdf.

Georgia Environmental Protection Division, 1997, Interim strategy for managing salt water intrusion in the Upper Floridan aquifer of southeast Georgia, April 23, 1997: Atlanta, GA, Georgia Environmental Protection Division, $19 \mathrm{p}$.

Grubbs, J.W., 1995, Evaluation of groundwater flow and hydrologic budget for Lake Five-O, a seepage lake in northwestern Florida: U.S. Geological Survey Water-Resources Investigations Report 94-4145, 42 p.

Krabbenhoft, D.P., Anderson, M.P., and Bowser, C.J., 1990, Estimating groundwater exchange with lakes, 2.Calibration of a three-dimensional, solute transport model to a stable isotope plume: Water Resources Research, v. 26, no. 10, p. 2455-2462.

LaForge, Lawrence, Cooke, C.W., Keith, Arthur, and Campbell, M.R., 1925, Physical geography of Georgia: Georgia Geological Survey Bulletin 42, 189 p.

Landry, Gill, Jr., 2009, Turfgrass water management (agronomy fact sheet): Cooperative Extension Service, The University of Georgia College of Agricultural and Environmental Sciences, online only accessed November 19, 2009, at http://pubs.caes.uga.edu/caespubs/pubcd/L399.htm.

Lee, D.R., 1977, A device for measuring seepage flux in lakes and estuaries: Limnology Oceanography, v. 22, p. 140-147.
Lee, T.M., and Swancar, Amy, 1997, Influence of evaporation, groundwater, and uncertainty in the hydrologic budget of Lake Lucerne, a seepage lake in Polk County, Florida: U.S. Geological Survey Water-Supply Paper 2439, 61 p.

Lohman, S.W., 1972, Groundwater hydraulics: U.S. Geological Survey Professional Paper 708, 70 p.

Mosner, M.S., and Aulenbach, B.T., 2003, Comparison of methods used to estimate lake evaporation for a water budget of Lake Seminole, southwestern Georgia and northwestern Florida, in Hatcher, K.J., ed., Proceedings of the 2003 Georgia Water Resources Conference, held April 23-24, 2003, at the University of Georgia: Athens, GA, Institute of Ecology, The University of Georgia.

Pollman, C.D., Lee, T.M., Andrews, W.J., Sacks, L.A., Gherini, S.A., and Munson, R.K., 1991, Preliminary analysis of the hydrologic and geochemical controls on acid-neutralizing capacity in two acidic seepage lakes in Florida: Water Resources Research, v. 27, no. 9, p. 2321-2335.

Priest, Sherilyn, 2004, Evaluation of groundwater contribution to streamflow in coastal Georgia and adjacent parts of Florida and South Carolina: U.S. Geological Survey Scientific Investigations Report 2004-5265, 40 p., accessed October 15, 2009, at http://pubs.usgs.gov/sir/2004/5265/.

Rantz, S.E., and others, 1982, Measurement and computation of streamflow-Volume 2-Computation of discharge: U.S. Geological Survey Water Supply Paper 2175, 603 p., accessed October 15, 2009, at http://pubs.usgs.gov/wsp/ wsp2175/pdf/WSP2175_vol2a.pdf.

Shaw, R.D., and Prepas, E.E., 1990, Groundwater-lake interactions, I.-Accuracy of seepage meter estimates of lake seepage: Journal of Hydrology, v. 119, p. 105-120.

Stewart, R.B., and Rouse, W.R., 1976, A simple method for determining the evaporation from shallow lakes and ponds: Water Resources Research, v. 12, no. 4, p. 623-628.

U.S. Army Center for Heath Promotion and Preventative Medicine, 2008, Golf course irrigation system source water feasibility evaluation (Project no. 32-EE-08GW-08), Hunter Army Air Field, Georgia [variously paged].

U.S. Environmental Protection Agency, 2009, Drinking water contaminants, accessed July 14, 2009, at http://www.epa. gov/safewater/contaminants/index.html\#content.

U.S. Geological Survey, 1998, Quality-assurance plan for groundwater: unpublished report on file at U.S. Geological Survey, Atlanta, GA [variously paged].

Winter, T.C., 1981, Uncertainties in estimating the water balance of lakes: Water Resources Bulletin, v. 17, no. 1, p. 82-115. 
Manuscript approved on December 10, 2009

For more information about this publication, contact: USGS Georgia Water Science Center

3039 Amwiler Road

Atlanta, GA 30360

telephone: 770-903-9100

http://ga.water.usgs.gov/

Edited by Kimberly A. Waltenbaugh

Graphics by Bonnie J. Turcott

Layout by Caryl J. Wipperfurth 
